\title{
Quetico Fishes
}

\section{E.J. CROSSMAN}

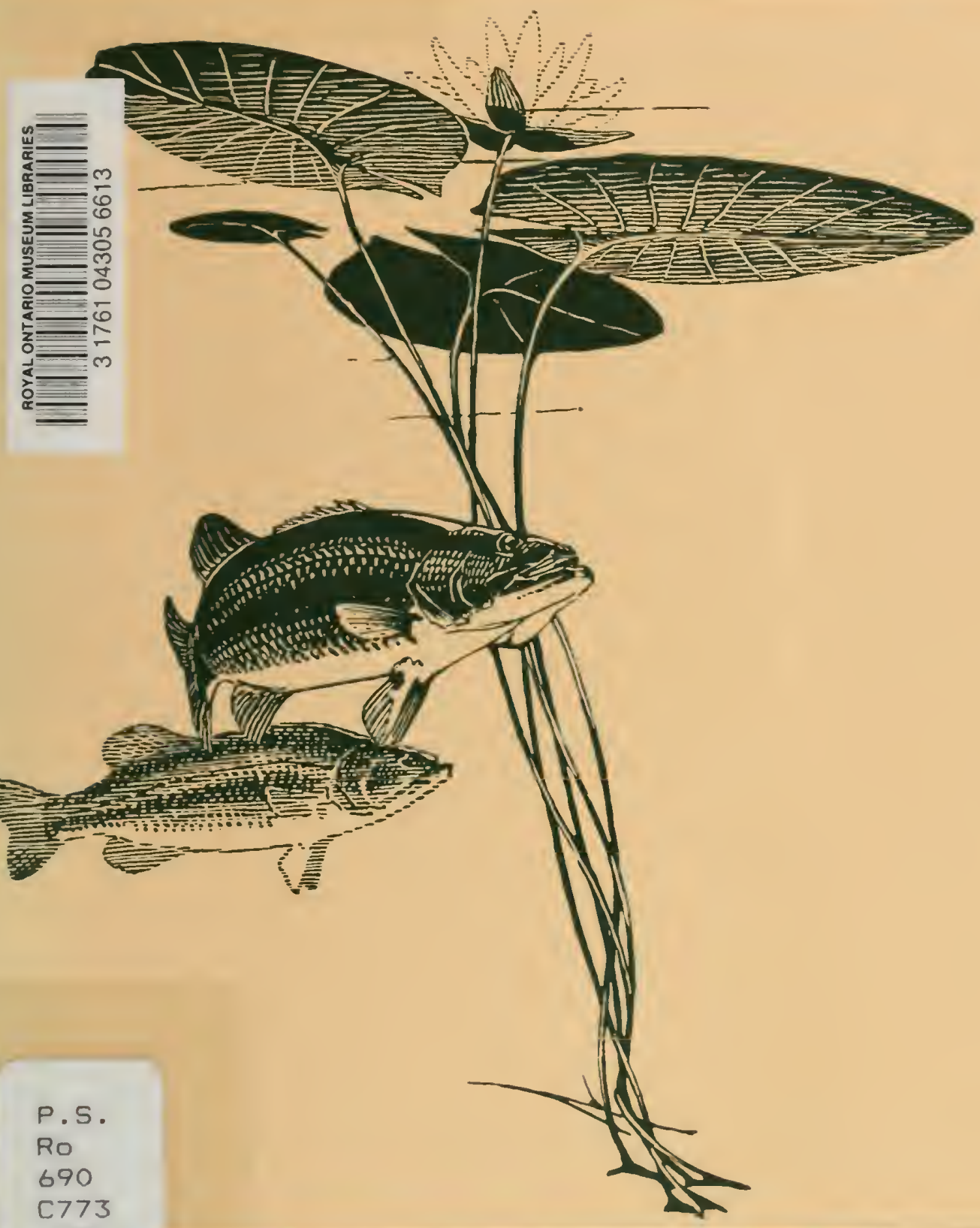

ROYAL ONTARIO MUSEUM 


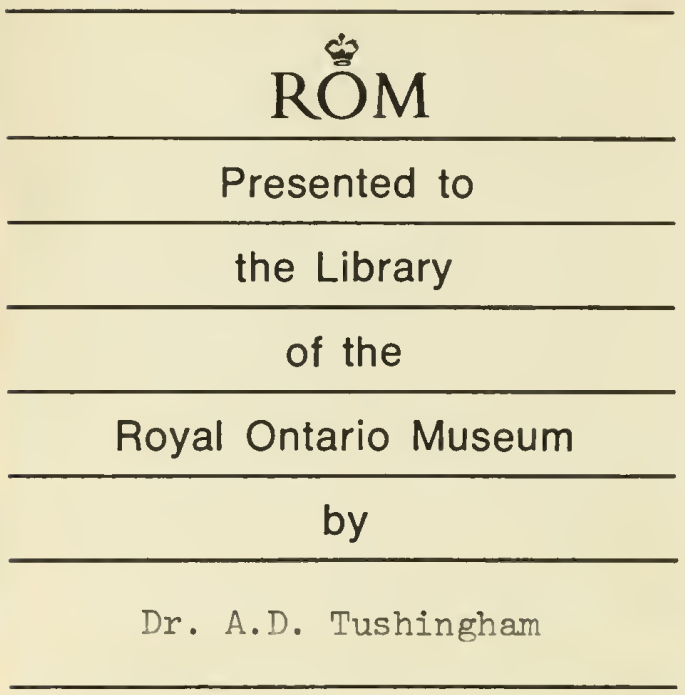

Dr. A.D. Tushingham

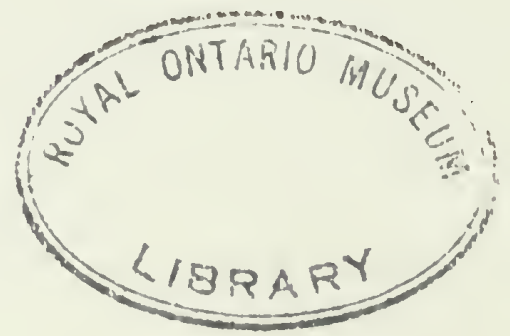




\title{
Quetico Fishes
}

\author{
E. J. CROSSMAN
}

Illustrated bi:

P. BUERSCHAPER

This publication was prepared with the sponsorship and the financial assistance of the Quetico Foundation and constitutes both a Life Sciences Miscellaneous Publication of the Royal Ontario Museum and one of the Foundation's series of publications. 


\section{ROYAL ONTARIO MUSEUM PUBLICATIONS IN LIFE SCIENCES}

The Royal Ontario Museum publishes three series in the Life Sciences:

I.IFI SCIENCES CONTRIBETIONS, a numbered series of original scientific publications. including monographic works.

LIFE SCIE NCIS OCCASIONAL. PAPI RS, a numbered series of original scientific publications, primarily short and usually of taxonomic significance.

LIFE SCIENCES MISCELLANEOUS PUBLICATIONS, an unnumbered series of publications of varied subject matter and format.

All manuscripts considered for publication are subject to the scrutuny and editorial policies of the Life Sciences Editorial Board, and to review by persons outside the Museum staff who are authorities in the particular field involved.

\section{LIFE SCIENCES EDITORIAL BOARD}

Chairman: WALTHR M. TOVILL

Editor: J C. BARIOW

Associate Editor: A.R. EMERY

Associate Editor: D.W. BARR

E.J. CROSSMAN is Curator in the Department of Ichthyology and Herpetology. Royal Ontario Museum, and Professor in the Department of Zoology. University of Toronto.

Peter Buerschaper is Chief Technician in the Department of Ichthyology and Herpetology. Royal Ontario Museum.

Cover illustration: "Large-mouthed Black Bass" by Francis Lee Jaques from Canoe Countr' by Florence Bage Jaques. Reproduced by kind permission of the University

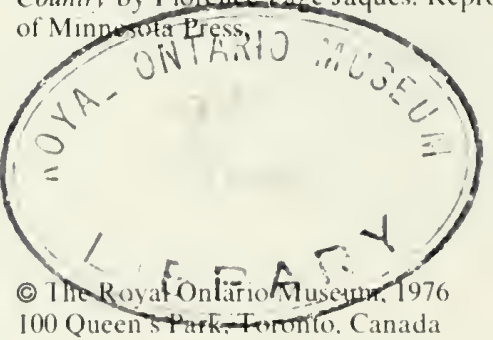

ISBN 0-88854-180-5

ISSN $0082-5093$

Publication date: 20 February 1976

Suggested citation: Life Sci. Misc. Pub., R. Ont. Mus. 


\section{Contents}

Foreword $v$

Preface vi

Introduction vii

Guide to Quetico Fishes 2

Checklist of Species 2

Species Accounts 4

1. Sport Fishes 4

2. Other Fishes 33

Distribution 54

1. List of Species and the Bodies of Water from Which They Are Known 54

2. Alphabetical List of Bodies of Water with the Species Known to Occur in Each 63

History of Quetico Fishes 75

Glacial History and Changes in Pathways for Fishes 75

Discussion of Fish Distribution 77

Commercial Fishing 81

Acknowledgments 82

Literature Cited and Suggested Reading 83

Index to Scientific and Common Names 85 


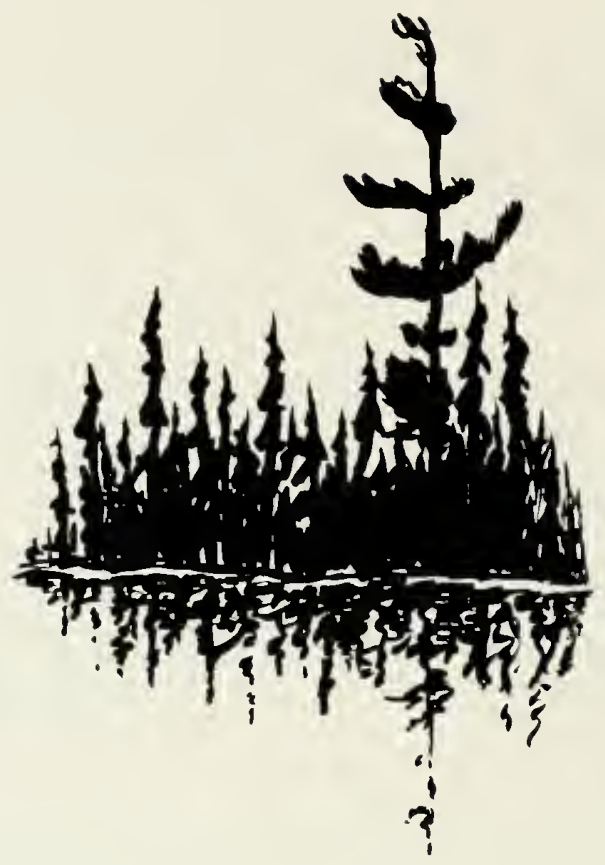




\section{Foreword}

Since its inception in the middle 1930s the Quetico Foundation has sponsored the production of a number of scientific papers and books for the purpose of stimulating continuing interest in the important values of wilderness parks. Both the public and governments, particularly in the earlier days, were greatly in need of such stimulation.

To this end the Foundation's trustees formed a scientific advisory committee composed of men prominent in their various scientific fields. The committee attracted many outstanding authorities to research and report on various phases of the essential natural resources in wilderness areas and, in particular, QueticoSuperior country, which straddles the international boundary west of Lake Superior.

Thus a most helpful association arose between the Foundation and the Royal Ontario Museum; indeed, the Rov's former Director, Dr. Walter M. Tovell, has been a member of the Foundation's Scientific Advisory Committee for several years and is at present its chairman. We enthusiastically accepted his suggestion that we sponsor the research and reporting by Dr. E. J. Crossman, which has resulted in this informative and interesting volume Quetico Fishes.

John B. Ridley

Chairman

The Quetico Foundation 


\section{Preface}

Museum curators of today whose responsibilities are within the disciplines of natural history are not just collectors and keepers. They apply their knowledge of the living things they collect and identify to such problems as what function is served by the organisms within a given biological community, or what migration routes were followed by the ancestors of the present species that populate a given community. Nowhere is the latter problem more intriguing than among the fish populations of the lakes of northern Ontario.

Five hundred generations ago this area, along with most of northern North America, was covered with ice. As the ice melted away the present lakes were formed. Where did the fish come from?

Dr. E. J. Crossman has been interested in this problem, and in particular, in the migration of certain species of fish into these lakes from the unglaciated regions of the Mississippi Valley. The Quetico region, with its magnificent wilderness park, is ideally situated to contribute data towards this long-term project. So it was that the Quetico Foundation welcomed the suggestion that Dr. Crossman collect and study the fish of Quetico Park and at the same time prepare a guide to them.

From the beginning, the Ontario government assisted in the programme, and in 1968 it provided a two-man crew to advance an intensive inventory of the fish of the park. The identifications were made by Dr. Crossman and his associates in the laboratories of the Royal Ontario Museum. The results of the joint venture, initially funded by the Quetico Foundation and the Museum, appear in the following pages. The documented collections, available for the professional and the serious naturalist to examine. form part of the collections of the Department of lchthyology and Herpetology of the Royal Ontario Museum.

Walter M. Tovell

Royal Ontario Museum

Chairman

Scientific Advisory Committee

Quetico Foundation 


\section{Introduction}

Wilderness parks appeal to different people for different reasons. They offer the tranquillity of travel by canoe. the enjoyment of life outdoors, and the opportunity to observe a natural fauna no longer available in urban situations. For some. wilderness parks provide. with a minimum of danger, the chance to test their ability to survive in the wild. A primary attraction to visitors to Ontario's parks, tourist and resident alike, is the opportunity to catch fish by angling.

Quetico Provincial Park supplies all of the above opportunities. Its fishes are, of course, the main attraction for anglers who use the park: but they may provide also a secondary interest for the casual camper or canoe tripper who wishes to learn to identify them in order to observe them as he does birds and mammals. It therefore seemed appropriate to provide the visitor with a simple guide to Quetico fishes. People interested in the fishes often want to know what species occur in the park, how they can be identified, where they can be found, and basic information about habitat, size, food, and life history.

The guide is an outgrowth of an inventory of the fishes of Quetico Provincial Park resulting from an intensive survey carried out between 1967 and 1973. The primary purpose of the inventory was to determine which species occurred in this semi-remote area, and whether new species of fishes were still moving northward into Canada through these waters. In all, 225 sites were sampled throughout the park. Various other records of fishes in the park, dating from the 1940 s, were also used.

The section of the guide called "Species Accounts" deals with two categories of fishes: (1) "Sport Fishes"- this category includes 16 species which the angler considers sport fishes or which the author considers to have potential for sport; (2) "Other Fishes" - a catalogue of 32 species of importance to the natural history of the park but of less significance to most people, either because of a traditional bias, or because of their small size or, as with the brook trout, their scarcity in the park. Some species (e.g., white sucker, Catostomus commersoni; burbot. Lota lota) which are good food and are often of significant size, but which are rarely considered acceptable by anglers either as sport or as food, are included in this category.

Fishes in the first category are more extensively treated, with notes, wherever possible, on means of recognition, distribution in the park, type of habitat in which the species was usually found, average size seen, size-age-weight relationships, food, and spawning habits, together with some comments on the species" utility. For "Other Fishes" similar data are provided in an abbreviated form. 
In the many cases where size relationships are not available for fishes in the park, the data for comparable areas outside the park are used. The original sources of these data can be found in Scott and Crossman (1973). When data were derived from other sources, it was not always possible to convert the units of measure to a standard. As a result length figures are given variously as total length (tip of the snout to the tip of the tail), or fork length (tip of the snout to the fork of the tail), or standard length (tip of the snout to the end of the last vertebra).

Different readers will be interested in the distribution information for different purposes. The angler or naturalist may wish to know where to go to find a certain species, or alternatively what species occur in the lake he is on. Zoogeographers may want detailed information on distribution for this remote area as a whole. For these reasons I have included a "List of bodies of water with the species known to occur in each" (p. 63), and a "List of species and bodies of water from which they are known" (p. 54). This may seem repetitive, but it provides the information in a form most convenient for the various users.

In both these lists and in the text discussion of distribution, Iocalities are generally represented by distinct bodies of water. If, in the inventory, the yellow perch was recorded at the mouths of five tributaries of Darky Lake, these records would here be considered as coming from the same locality, Darky Lake. Hence the number of localities for the longnose dace (p. 57) is 26 , but the species was taken from 10 lakes or ponds and 23 rivers or streams. The only deviation from this system involves the large, named, lake-like bays (e.g.. Ranger Bay of Basswood Lake) of the very large lakes. These bays are included by name since they are often thought of as separate lakes. For many species there are also more indefinite records for the large lakes. These are taken from older records which state simply, e.g., "occurs in Basswood Lake".

The only body of water listed which is outside the park boundaries is Eva Lake. It is included because it is adjacent to the park, is tributary to French Lake (the main campground for QPP), and is used by many anglers camping in the park.

In the text discussion of the distribution of each species there is a note of the number of locations from which that species is known, followed in brackets by the percentage that number constitutes of the total number of locations (195). This, of course, differs from the total number of collecting sites of the inventory (255). The percentage is followed by the rank held by that species in regard to frequency of occurrence of all species. These figures also appear to the right of the species name in the distribution list. The lowest rank is 3I. When several species had the same frequency of occurrence, each was given the same rank.

In the "Alphabetical list of bodies of water with the species known to occur in each" (p. 63), a considerable discrepancy in the amount of information on each location will be obvious (e.g., Conmee Lake, 2 species: Crooked Lake, 25 species). The sources of the information from which this list was prepared ranged from the results of the inventory to various informal notations in the Ontario Ministry of Natural Resources records of sport fishes known to occur in various waters. More information on the fauna of those locations for which only a few 
species are listed would be very helpful. However, the records must be authentic. and for many species will have to be based on a preserved specimen sent to the Royal Ontario Museum for accurate identification.

In the distribution lists reference is made to lakes by number and block. These designations are for unnamed lakes in the park and are based on a gridded map referred to as the Quetico Forestry Plan. Copies of this map are on file in the Atikokan Ontario office of the Ontario Ministry of Natural Resources: the Environmental Dynamics Section, Sport Fisheries Branch. Ontario Ministry of Natural Resources. Toronto; and the Department of Ichthyology and Herpetology. Royal Ontario Museum. In some places unnamed lakes that are part of that grid designation are given in the lists as "lake between A Lake and B Lake" and can be located without reference to these special maps.

The standard for the spelling of the names of lakes and rivers is the older Quetico Map, Map 56a. Ontario Department of Lands and Forests, 1956.

The three most important factors governing the present patterns of distribution of Ontario's fishes are glaciation, periodic connection and separation of strean systems, and the activities of man. In all these respects Quetico is well suited to the study of the processes that influence fish distribution. The role of glaciation, its effects on the pathways available to fishes migrating northward in the Quetico region, and the patterns of distribution of fishes in that part of North America, are treated in the section entitled "History of Quetico Fishes" (p. 75).

The third factor, man, has seriously altered the slow, natural process of fish distribution in Ontario. He has introduced species not previously present (rainbow trout, Salmo gairdneri). and he has extended the range of some native species within the province. Such introductions have usually been deliberate (smallmouth bass. Micropterus dolomieui), but they have not always been advantageous. The northward spread of the basses from the border waters of Quetico is attributed to one of these deliberate introductions. Introductions in other parts of Ontario may have been the result of the haphazard release of bait fishes or the unintentional escape of domestic stock (carp, Cyprinus carpio). Man has attempted to adjust selectively, for his own ends, the relative numbers of what he considered "desirable" and "undesirable" species. Introductions and selections affect, among other things, our ability to clarify what went on in nature after the glaciers receded and aquatic habitats were once more available in Ontario. In the wilderness parks, however, the composition of the fish faunas has been less changed by the processes mentioned above than in most other areas. Anglers are not allowed to bring live bait fishes into the park. Lakes beyond the perimeter are probably safe from contamination from bait pails as bait fishes would have to be packed in.

This guide to Quetico fishes ends with a list of literature and an index. The list of literature includes both references used for facts given in the text and other sources to which people interested in the Quetico area can turn for further information. The index indicates, by scientific name and by the presently "accepted" common name, the location in the text of both the write-up for a particular species and the area within the distributional list dealing with that species. 


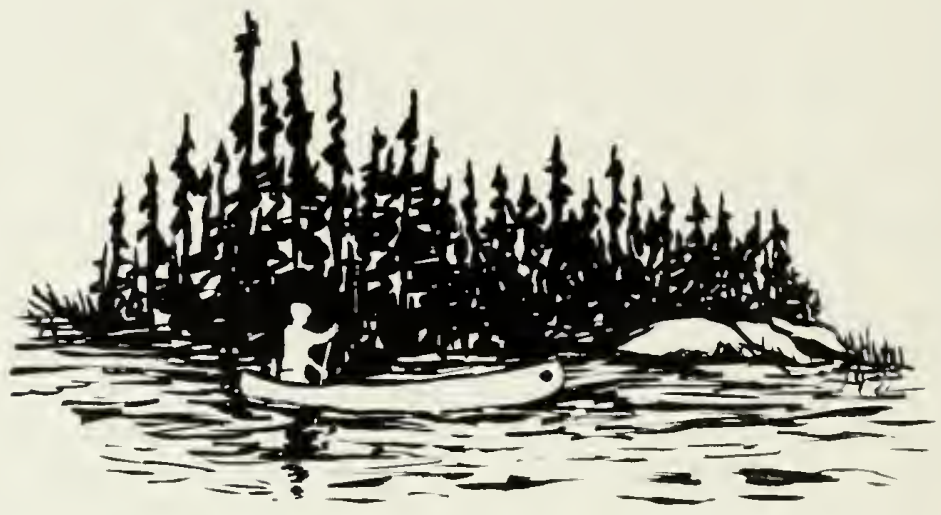




\section{Quetico Fishes}




\section{Guide to Quetico Fishes}

\section{CHECKLIST OF SPECIES}

The fishes are listed here in the usual taxonomic order. This is not necessarily the order in which they are treated in the text. The scientific names follow Scott and Crossman (1973).

Lampreys

Silver lamprey

Sturgeons

Lake sturgeon

Salmons and related fishes

Brook trout

Lake trout

Cisco

Shortjaw cisco

Lake whitefish

Smelts

Rainbow smelt

Mooneyes

Mooneye

Mudminnows

Central mudminnow

Pikes

Northern pike

Carps or minnows

Northern redbelly dace

Finescale dace

Lake chub

Golden shiner

Emerald shiner
Family Petromyzontidae

Ichthyomyzon unicuspis

Acipenseridae

Acipenser fulvescens

Salmonidae

Salvelinus fontinalis

Salvelinus namavcush

Coregonus artedii

Coregonus zenithicus

Coregonus clupeaformis

Osmeridae

Osmerus mordax

Hiodontidae

Hiodon tergisus

Unbridae

Umbra limi

Esocidae

Esox lucius

Cyprinidae

Chrosomus eos

Chrosomus neogaeus

Couesius plumberus

Notemigonus crisoleucas

Notropis atherinoides 
Common shiner

Blackchin shiner

Blachnose shiner

Spottail shiner

Mimic shiner

Bluntnose minnow

Fathead minnow

Blacknose dace

Longnose dace

Pearl dace

Creek chub

\section{Suckers}

White sucker

Silver redhorse

Shorthead redhorse

Catfishes

Tadpole madiom

Cods

Burbot

Trout-perches

Trout-perch

Sunfishes

Rock bass

Green sunfish

Pumpkinseed

Bluegill

Longear sunfish

Smallmouth bass

Largemouth bass

Black crappie

Perches

Iowa darter

Johnny darter

Yellow perch

Log perch

Sauger

Walleye

Sculpins

Motiled sculpin

Slimy sculpin
Notropis cormutus

Notropis heterodon

Notropis heterolepis

Notropis hudsonius

Notropis solucellus

Pimephales notatus

Pimephales promelas

Rhinichth's arratulus

Rhinichthys cataractae

Semotilus margarita

Semotilus atromaculatus

Catostomidae

Calostomus commersoni

Moxostoma anisurum

Moxostoma macrolepidotum

Ictaluridae

Noturus gyrinus

Gadidae

Lota lota

Percopsidae

Percopsis omiscomaycus

Centrarchidae

Ambloplites rupesiris

Lepomis cyanellus

Lepomis gibbosus

Lepomis macrochirus

Lepomis megalotis

Micropterus dolomieui

Micropterus salmoides

Pomoxis nigromaculatus

Percidae

Etheostoma exile

Etheostoma nigrum

Perca flavescens

Percina caprodes

Stizostedion canadense

Stizostedion vitreum

Cottidae

Cormus bairdi

Cortus cognatus 


\title{
SPECIES ACCOUNTS
}

\author{
1. Sport Fishes
}

\section{Lake Sturgeon-Acipenser fulvescens}

The lake sturgeon and the northern pike are the largest fishes in the park. The sturgeon is easily distinguished from all other Quetico fishes by its long, sloping. bluntly pointed snout; the four whisker-like barbels on the undersurface of the snout: the ventral and posterior position of the suctorial mouth; the five rows of bony plates on the otherwise scaleless body; and the heavy, large upper lobe of the caudal fin.

The lake sturgeon is at present known only from four lakes, or $2.1 \%$ of the locations, and ranks $28 \mathrm{th}$ with the fathead minnow. The waters in which it is known lie in a diagonal line from Eva Lake southwest to Lac la Croix, but it may be present in many more of the larger lakes and large rivers (see p. 54).

The lake sturgeon is a bottom dweller, usually found in cool water on highly productive shoal areas, where it feeds. Its usual depth preference is 15-30 feet. but it is known to occur as deep as 140 feet.

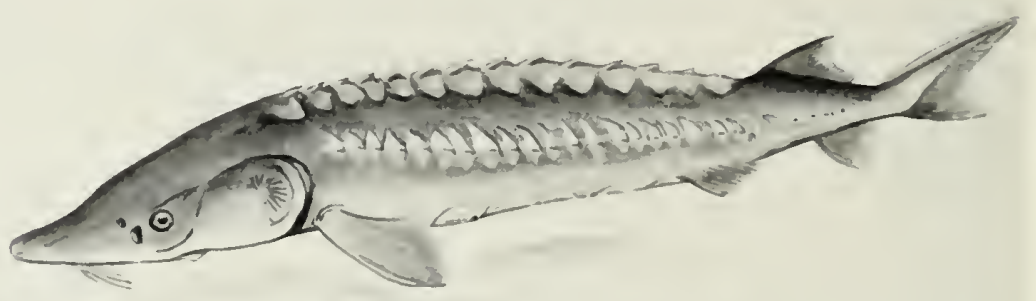


Individuals most often seen are 3-5 feet in total length and weigh $10-18$ pound. At this length they are approximately $20-30$ years of age. The largest lake sturgeon seen in Canada was 7 feet 11 inches in total length and weighed 310 pounds. This species is very slow growing and long lived. Males. on the average. spawn for the first time at 15-20 years of age. and females at 25-33 years. The capture of even a moderately large lake sturgeon may remove a fish from the stock before it has contributed to the reproduction of the stock.

The figures (ranges) for Lake Nipigon on page 8 approximate the relationships between total length. weight, and age for this species in Quetico.

The food of the lake sturgeon of all sizes is made up of small organisms, such as cravfish, insect larvae, and leeches, which it sucks up off the bottom with its protrusible mouth.

Lake sturgeon usually spawn from late May to June, in rapids or swift water. Spawning takes places in shallow water, and at times the large spawners leap out of the water to fall back with a loud splash. No nest is built.

Fresh sturgeon is not very palatable to most people. since it is oily, but smoked sturgeon is a gourmet item. The eggs of the species, black in colour, are used in the preparation of caviar.

\section{Lake Trout-Salvelinus namaycush}

This, the only abundant trout in Quetico, is distinguished from the brook trout by its overall ground colour, varying from metallic blue or pale green to almost black: numerous white to cream coloured spots; and the deeply forked tail. The

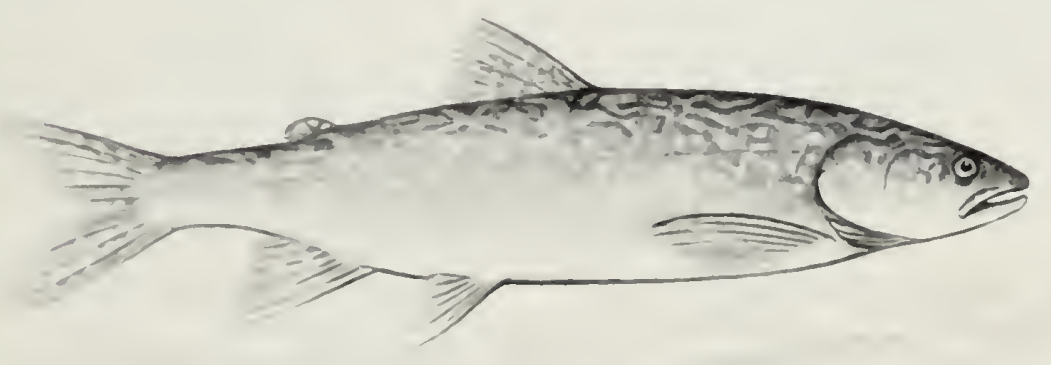




\section{ANATOMICAL FEATURES USED IN SPECIES ACCOUNTS}

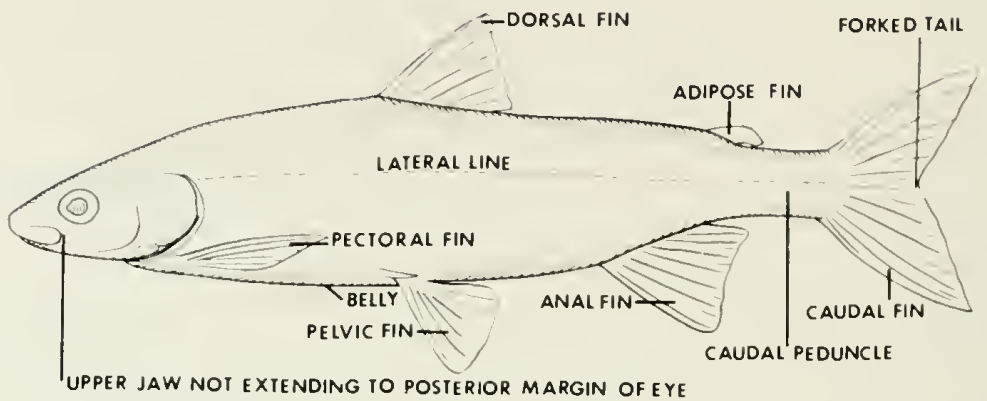

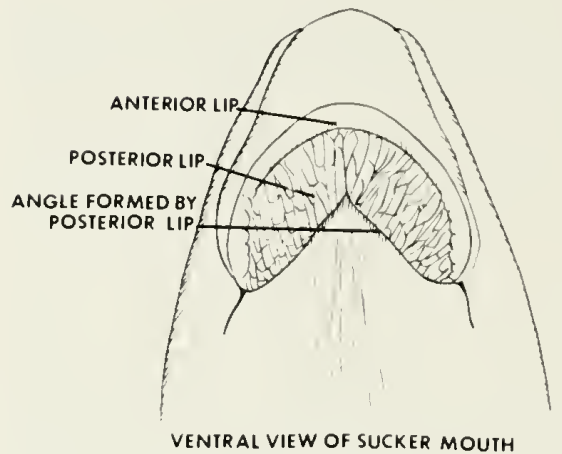

VENTRAL MOUTH
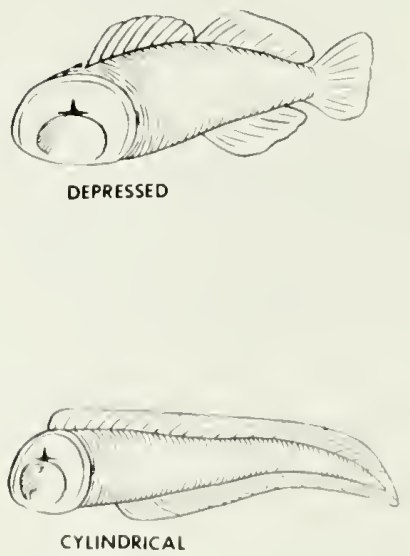
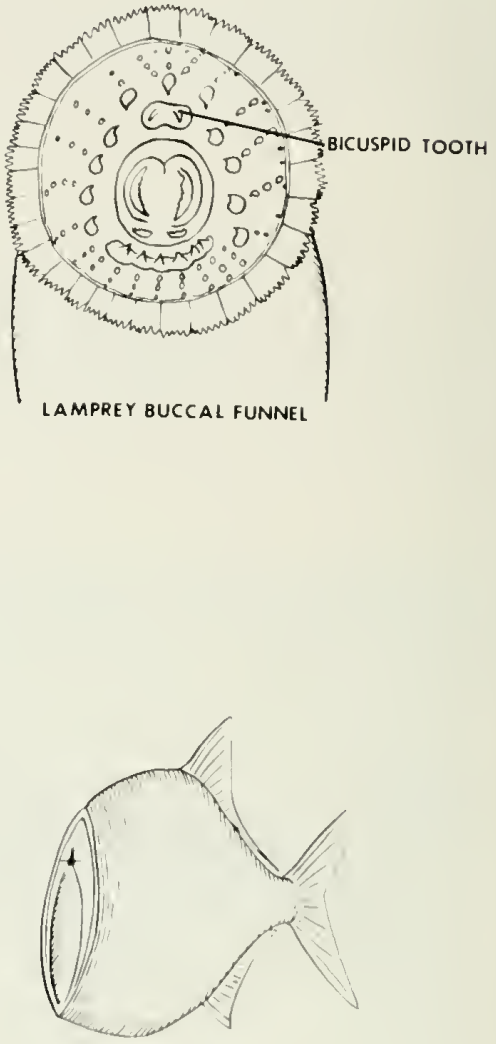

COMPRESSED

Fig. 1 Anatomical features used in Species Accounts 

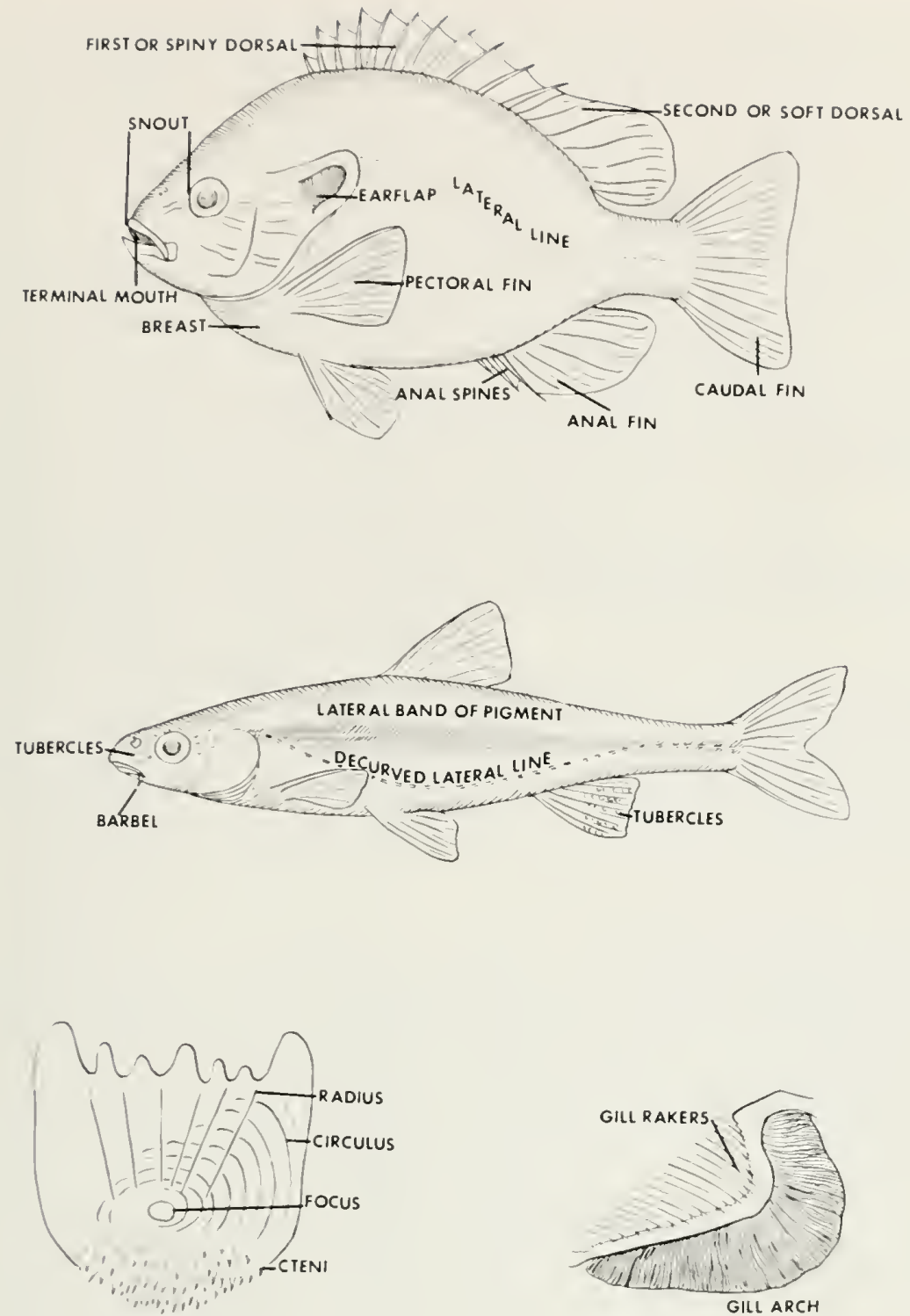

CTENOID SCALE

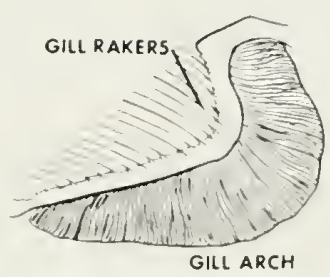

INCHES $\times 2.54=$ CENTIMETRES

OUNCES $\times 28.3495=$ GRAMS

FEET $X 0.3048=$ METRES 
8 QLeTICO FISHES

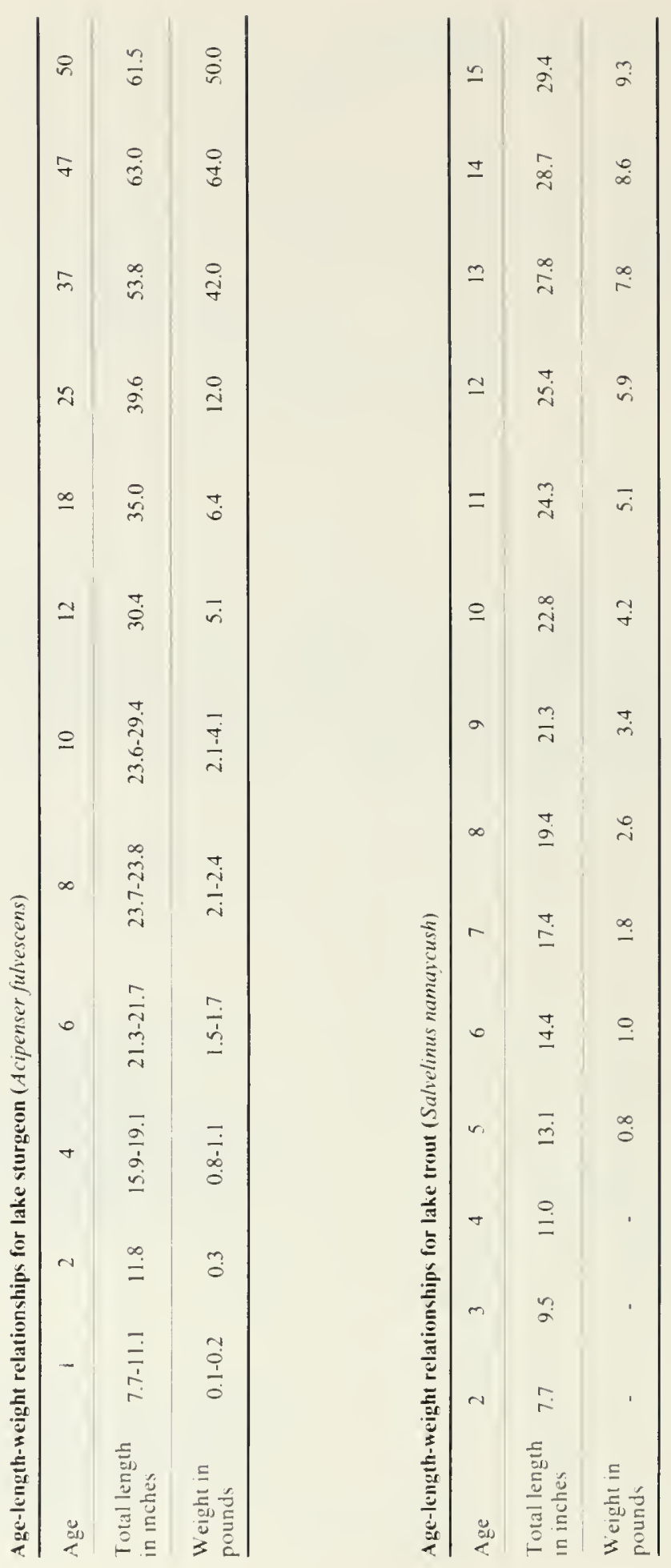


very largest individuals may be a general silver colour. which masks the prominent spotting. The above characteristics distinguish the lahe trout from all other species in the park.

The lake trout is widely distributed through the park (see p. 54) and has been laken in 77 different locations (39.5\%, ranks 4 th).

Lake trout are cold-water fish. They prefer water temperatures of about $50^{\circ}$ and usually occur in relatively deep lakes. In summer this species is most often found at depths of 40-60 feet, but it has been known to occur as deep as 175 feet. In spring and fall, when the upper water is cooler, it is seen in much shallower water and can often be taken by bait-casting techniques.

Those taken in the park are usually 15-22 inches in length and weigh 1-5 pounds. Ai these sizes they are probably 5-10 years of age. The figures (averages) for Lake Opeongo in Algonquin Park, given on page 8, probably approximate the relationships for lake trout in Quetico.

Lake trout are usually capable of reproducing by the age of 6 or 7.

The largest known lake trout, caught in Lake Athabasca, Saskatchewan, was 49.5 inches long and weighed 102 pounds, but the angling record is a trout of 63 pounds 2 ounces caught in Lake Superior.

This, the largest of the trouts, is also the most omnivorous. It consumes a broad range of animals, including plankton, insects, fishes, and occasionally even small mammals. Where lake trout and ciscoes occur in the same lakes at the same depth, ciscoes are often the main food item of at least the larger trout.

The lake trout spawns in the fall, at night, and generally over areas of broken rock. The eggs are laid and fall into the crevices between the rocks, but no real nest is built.

A hybrid trout called splake or wendigo has received much attention elsewhere. The splake results from crossing lake trout eggs and brook trout sperm. There is no record of this hybrid's having been introduced in Quetico waters.

Lake trout are usually caught by trolling a heavy line and heavy lure near the bottom in deep water along shores or shoals. These lures are usually bright spoons or wobblers. Large bait fish can be trolled as well and, in some situations outside Quetico, are used when still fishing for lake trout. Calculations in the past have yielded catch figures for Quetico lakes of 61-152 lake trout per 100 boat hours. Because of the type of angling required, this species is not often sought after by canoeists. Fewer anglers are in the park during the periods in spring and fall when lake trout might be taken by casting in the shallower water. In the past, resorts on the Border Waters remained open for this type of angling after the usual season. Agnes, Louisa, and Eva lakes are known for their lake trout, and anglers go there seeking them. Elsewhere. lake trout are usually taken incidentally when trolling for walleye or northern pike.

This trout is highly prized, as it is rich and flavourful. Lake trout hot-smoked for a day can be used as storage rations for a few days. The ovaries and testes of large lake trout make excellent food when fried. because they do not taste fishy and may provide relief from a steady survival diet of fish fillets. 


\section{Cisco (or lake herring)-Coregonus artedii}

This silvery, trout-like fish can be distinguished from the trouts by the absence of coloured or black spots, the virtual absence of teeth, and the many fine gill rakers. It can be distinguished from the closely related lake whitefish by its pointed snout and terminal mouth, since the lake whitefish has a rounded snout, subterminal mouth, and fewer, heavier gill rakers.

The cisco is widely distributed in the park (see p. 54), but is not particularly abundant anywhere. It was taken in 34 different localities (17.4\%, ranks 12 th).

In Quetico, this species rarely exceeds 12 inches in length and is usually 5-10 inches. There is a record of a cisco of 17 inches caught in Lac la Croix in 1963. The average weight in Quetico would probably be $1 / 2-1$ pound. Maximum recorded size would appear to be an 8-pound female from Lake Erie. No agelength records are available for Quetico, but the figures given here for Lake of the Woods probably approximate those for at least the larger Border Waters lakes.

\begin{tabular}{lcccccccccc}
\hline Age & 1 & 2 & 3 & 4 & 5 & 6 & 7 & 8 & 9 & 10 \\
$\begin{array}{l}\text { Average standard } \\
\text { length in inches }\end{array}$ & 4.2 & 6.3 & 8.2 & 9.7 & 10.8 & 11.6 & 12.6 & 13.2 & 15.0 & 15.8 \\
\hline
\end{tabular}

In some Quetico lakes, what seem like two distinct populations of this species occur. Superficially, one group comprises larger. more compressed. deeperbodied individuals that become sexually mature at $8-10$ inches. The other group consists of smaller, rounder individuals that are mature even at a length of $4-6$

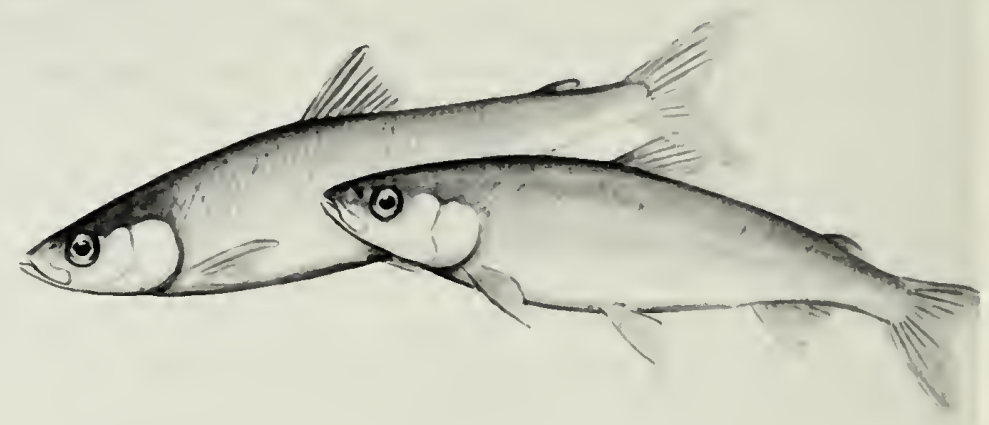


inches. Further reports from the lakes in which this plenomenon oceurs would aid in understanding its significance.

There is in the park at least one cisco other than $C$. artedii. An old Rou collection taken in 1944 from Basswood Lake. labelled Coregonus (Leucichths) sp., contained five individuals. Dr. W.B. Scott has recently identified these as one C. artedii and four shortjaw cisco, C. zenithicus. The latter will not be treated fully here, but all collections of ciscoes from Quetico should be critically examined for it. Another species, the bloater, $C$. hoyi. was reported from Eva Lake by Lindeborg (1941). This record was the only one outside the Great Lakes and was based on a single small specimen collected in 1935 and housed in the collection of the Museum of Zoology. University of Michigan (L M:12 127663). This specimen has been reidentified by Dr. Scott as $C$. artedii, a species known to occur in Eva Lake.

This species is rarely seen even by regular visitors to the park. Ciscoes are usually conspicuous only in spawning runs into the shallow's in late fall, when all but the hardiest people have deserted the park. They are not a primary sport fish in Quetico, but are very desirable as food. In shallower water they can be taken with live bait, small lures, or flies. If schools can be found in summer, ciscoes can be caught with live bait. but they have rather delicate mouths and success requires a light touch.

\section{Lake Whitefish-Coregonus clupeaformis}

This silvery to golden-brown fish, when small, superficially resembles the trouts. However. it is distinguishable from them by being more compressed, by its lack of coloured or black spots, by its lack of teeth, and by the rounded snout and subterminal mouth. The last two characteristics also distinguish the lake whitefish from the related, but smaller, cisco.

The species is widely distributed throughout the park (see p. 55) and was taken at 26 localities (13.3\%, ranks 14th with the longnose dace). As with other deep-water species. the number of places from which it is known will probably increase when suitable collecting is done in other locations.

Like the lake trout and cisco. this species is usually found in lakes rather than in streams, as is implied by its name. It prefers cooler water and resorts to deeper areas as the waters warm in the summer. Summer depth ranges from 60 to 174 feet. Lake whitefish may be found in shallower water in the winter and spring. and they return to the shallow's in the fall to spawn. This species is often associated with the bottom at the depths given.

Lake whitefish netted in Lac la Croix ranged from 12 to 23 inches in length. but 15 inches is the probable average. The largest lake whitefish known elsewhere was one of 42 pounds taken from Lake Superior.

No data are available for Quetico on the relationships between weight. length. 


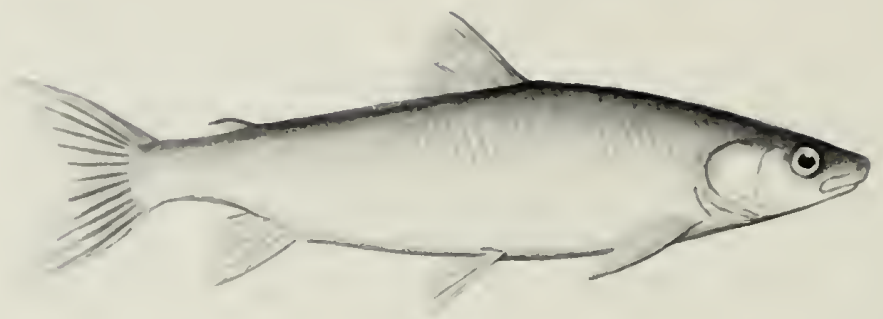

and age, but the data below (averages), for Lake Superior, should approximate the relationships for Quetico lake whitefish.

\begin{tabular}{lcccccccccc}
\hline Age & 1 & 2 & 3 & 4 & 5 & 6 & 7 & 8 & 9 & 10 \\
$\begin{array}{l}\text { Total length } \\
\text { in inches }\end{array}$ & 9.1 & 14.0 & 16.4 & 18.2 & 18.8 & 19.1 & 18.4 & 18.5 & 20.8 & 24.5 \\
$\begin{array}{l}\text { Weight } \\
\text { in pounds }\end{array}$ & 0.2 & 0.9 & 1.5 & 2.1 & 2.4 & 2.5 & 2.2 & 2.2 & 3.2 & 5.6 \\
\hline
\end{tabular}

As with the cisco, it is possible that there are two types of whitefish in some Quetico lakes-so-called "dwarfs" which never exceed 6 or 8 inches in length and are sexually mature at these sizes, and "normal" whitefish which grow to over 20 inches in length and are never mature at 6 inches. If this phenomenon is discovered, it should be reported.

These whitefish are bottom feeders, but at times even surface insects are taken. The usual food consists of a wide variety of bottom-dwelling invertebrates, but some plankton and occasionally small fishes are eaten.

This species is also a fall spawner, and in Quetico spawning probably takes place in late October or November. The adult fish move into shallower water. often less than 25 feet deep, and eggs are scattered over a rocky or sandy bottom. No nest is built.

Lake whitefish will not often be seen by anglers or canoeists in Quetico. They are. however, much more available during the fall migration into shallow water, and through the ice in winter. Minnows are the usual bait for lake whitefish, and a small hook must be used. Where populations are known to occur, summer angling in 40-60 feet of water might take this species. They are excellent as 
food, and one can take a steady diet of lake whitefish more easily than one of lake trout. Like the trouts, lake whitefish can be readily and appetizingly smoked for storage rations.

\section{Northern Pike-Esox lucius}

This is one of the best-known species in the park. It is distinguished from all other species by its long. cylindrical body, its large head, its duck-billed snout armed with large teeth, the posterior placement of its dorsal and anal fins, and its green to brown colour with horizontal rows of cream to white, bean-shaped spots. The muskellunge, which superficially resembles the northern pike, does not occur in the park.

The northern pike is the most widely distributed species in Quetico Park (see p. 55). It is presently known from 152 locations $(77.9 \%$, ranks Ist) and probably occurs almost everywhere.

Northern pike inhabit clear, warm meandering streams, small lakes, or bays of larger lakes. They are fishes characteristic of the top I 5 feet of water but may move into deeper water in the warmest periods of summer. They are not particularly active, and they usually lie in cover, dart out after individual prey, and return to cover. Areas of extensive vegetation, such as water lilies and pondweed, or submerged stumps and logs are likely places for northern pike.

In various Quetico lakes northern pike taken by anglers have ranged from 14 to 38 inches and have averaged 23 inches. The present angling record for this

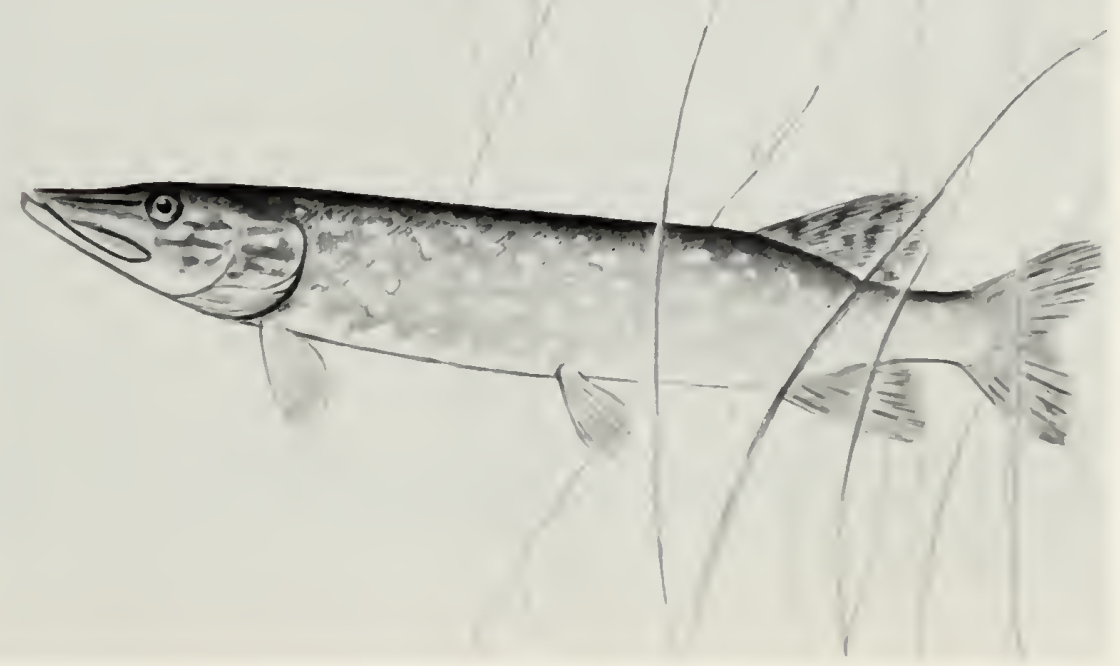


species in Canada is 42 pounds 12 ounces, but northern pike of $30-40$ pounds win annual contests in Ontario.

Figures on ages of northern pike in Quetico are scarce, but what there are suggest that the relationships between age, length, and weight are probably as follow's:

\begin{tabular}{lcccccccccc}
\hline Age & 1 & 3 & 5 & 7 & 9 & 10 & 11 & 12 & 13 & 14 \\
$\begin{array}{l}\text { Total length } \\
\text { in inches }\end{array}$ & $5-7$ & $13-18$ & $18-21$ & $23-26$ & $26-29$ & $27-31$ & $29-33$ & $31-36$ & $33-37$ & $36-38$ \\
\hline $\begin{array}{l}\text { Average weight } \\
\text { in pounds }\end{array}$ & - & 1.5 & 2.8 & 4.0 & 6.0 & 8.0 & 10.0 & 12.0 & 14.0 & 16.0 \\
\hline
\end{tabular}

It is possible that northern pike of greater length and weight, and of ages up to 18 years, occur in the park.

The northern pike is a predator, feeding on plankton for only the first few weeks of life, and thereafter almost entirely on other fishes. Frogs, muskrats, and ducks form a part of the diet of larger individuals. The angler is reminded that, when fishing for northern pike, larger bait is needed for larger pike.

Northern pike spawn in the spring soon after the ice has melted. There is no nest, and spawning usually takes place among the vegetation in temporary marshes on flooded banks, or in small streams.

This species, although probably the most widely distributed sport fish in the park, is second to the walleye in popularity. It is not usually fished for directly, but taken when anglers are trolling for walleye. Usually only the larger individuals are kept. It can be taken by trolling live bait, large plugs, spoons, or spinners, by casting these same lures into likely spots, or by still fishing with large bait fishes.

Angler success across the park apparently varies from 22 to 314 per 100 boat hours. The figure could be higher if the species were angled for specifically.

The northern pike is usually considered inferior as food. partly because of the many forked bones which lie between the muscles. However, much of what is usually thought of as its muddy flavour can be avoided by skinning rather than scaling the fish. With care in preparation, this species can be as palatable as any other.

Although the muskellunge, Esox masquinongy, occurs in Lake of the Woods, Rainy River, Rainy Lake, and to the south in Minnesota, there are no authentic records from Quetico. An esocid with unusual pattern was caught by an angler in Poohbah Lake in 1974. A colour slide of it shows a superficial resemblance to a muskellunge, but from the angler's description it would seem more likely to be a "silver pike". This is a relatively rare colour mutant of the northern pike that occurs throughout the worldwide range of the species. This form is characterized by an overall silver-green or silver-blue sheen and by the absence of the yellow spots so typical of the northern pike. 


\section{Rock Bass-Amblopites rupestris}

This is the largest of the typical sunfishes in the park and is most of ten 6-12 inches in length. As in the other sunfishes, the spiny- and soft-rayed portions of the dorsal and anal fins are connected. The distinctive characteristics that distinguish the rock bass from other sunfishes, as well as from other kinds of fishes, are the large red eye. the olive to golden brown body with 8-10 rows of spots (one per scale) on the sides below the lateral line, and the absence of a pronounced ear flap. The pectoral fins are short and round.

The rock bass is probably in every part of the park (see p. 58) where suitable habitats-rocky areas in shallow parts of lakes, or the warm mouths of slower streams-are found. Only nine species were seen more often than this one. It was taken from 40 different locations. hoth lakes and streams $(20.5 \%$. ranks 10 th).

Since the maximum length for this species seems to be just over 13 inches, rock bass in the park achieve adequate growth in length but probably never exceed $I_{2}$ pound in weight, whereas farther south they occasionally reach 3 pounds. Rock bass can live to be 10-12 years of age. The average figures below, based on catches in Quetico and elsewhere, give the approximate relationship between age and length.

\begin{tabular}{lcccccccccc}
\hline Age & 1 & 2 & 3 & 4 & 5 & 6 & 7 & 8 & 9 & 10 \\
$\begin{array}{l}\text { Total length } \\
\text { in inches }\end{array}$ & 1.5 & 3.5 & 4.5 & 6.5 & 7.5 & 8.5 & 8.7 & 9.0 & 9.5 & 10.0 \\
\hline
\end{tabular}

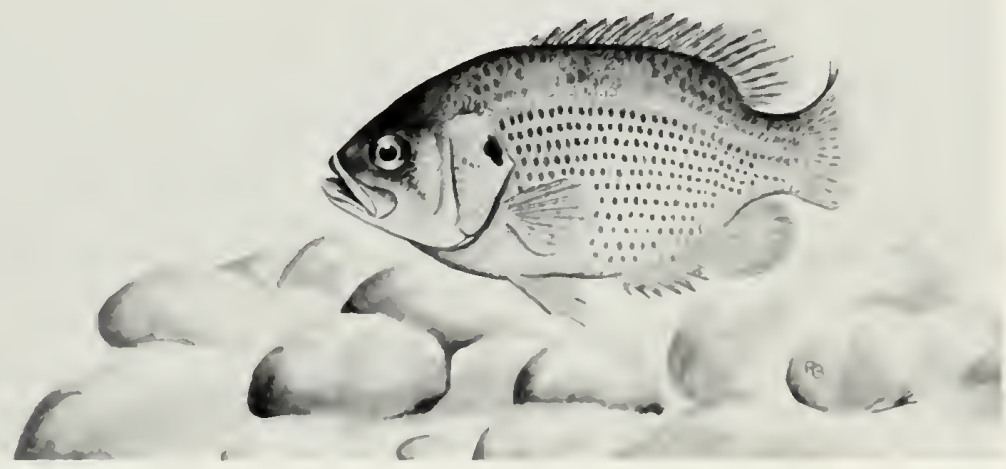


The rock bass is voracious, feeding on a wide variety of items from aquatic insects to crayfish and, to a lesser extent, small fishes. Anglers still fishing in shallow water have difficulty getting any kind of live bait past rock bass. They are probably strong competitors for food with at least the young of larger. more valued species like the basses.

This sunfish builds a nest 2 feet in diameter in almost any type of shallow water. and spawns in early summer. At that time it is very aggressive and will attempt to chase even swimmers away from its nest area.

Rock bass are readily caught on almost any bait: in fact. where there are large schools of them, it is of ten almost impossible to catch anything else. even with lures almost as large as the fish itself. Mostly ignored by anglers, this species is a lot of fun with very light tackle and flies, lures, or live bait. It is also one of the sweetest and most enjoyable fishes to eat.

\section{Green Sunfish-Lepomis cyanellus}

This deep-bodied, laterally compressed sunfish has a large mouth and large eyes. Adults are distinguishable from other sunfishes by the emerald sheen; 7 to 12 dark, vague, vertical bars on the upper side: emerald spots on the head: a rather large black earflap with a uniform border of red, pink, or yellow; dorsal, caudal, and anal fins edged in white, yellow, or orange; and a vague black spot at the base of the soft dorsal fin. The pectoral fins are short and rounded. The young, when less than 2 inches in length. are difficult to tell from other sunfishes.

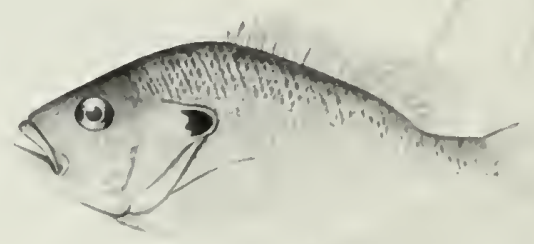


In Quetico this species is found mostly in the Boundary Waters but is known to be in Cirrus Lake in the northwest (see p. 58). It was taken in a total of 12 locations (6.2\%, ranks 23 rd with the shorthead redhorse). Opportunities to see this species may be better in the park than elsewhere in Ontario, where it occurs. sparingl! only in the Thames-Avon system tributary to Lake St. Clair.

This species is found in habitats ranging from the shallows of moderate-sized lakes to rather small streams. It often frequents dense growths of emergent vegetation.

This is a rather small species which rarely exceeds 5 inches in length in the parh and is sexually mature at 3 inches. In the southern part of its range. individuals reach a length of 12 inches and a weight of 2 pounds. In spite of its small size, its life expectancy is 7-9 years. The data helow give the average relationship between age and length for Michigan. where the stock is probably faster growing.

\begin{tabular}{|c|c|c|c|c|c|c|c|}
\hline Age & 1 & 2 & 3 & 4 & 5 & 6 & 7 \\
\hline $\begin{array}{l}\text { Standard length } \\
\text { in inches }\end{array}$ & 1.7 & 2.5 & 3.4 & 4.0 & 4.9 & 5.2 & 6.0 \\
\hline
\end{tabular}

Green sunfish apparently feed on insects, molluses, and small fishes.

This species builds a nest and spawns from mid-May to early August.

Green sunfish are too small to constitute an important sport fish, hut will provide enjoyment with very light tackle. They are an attractive fish and are. of course, edible.

\section{Pumphinseed-Lepomis gibbosus}

This somewhat larger sunfish is recognizable by its smaller mouth: radiating turquoise lines across the head: a prominent, but short, hlack earflap fringed with a narrow horder of yellow and a red spot at the lower edge; a broken-up body colour giving the appearance of spots; vague vertical hars on the sides: a bronze breast: and long, pointed pectoral fins. The dorsal fins have black pigment broken into apparent rows of vague spots.

This species is the most common and widely spread of the typical sunfishes in Ontario as a whole. Although less common and less abundant in the park than in southern Ontario, it still outranks the other small sunfishes, except for the rock bass. It was taken from 14 localities (see p. 58) over the whole area $(7.2 \%$. ranks 22 nd with the golden shiner).

The pumpkinseed occurs in the shallow water of small lakes, ponds, weedy bays of larger lakes, and slow-moving streams. It is usually associated with cover, such as stumps or vegetation. 


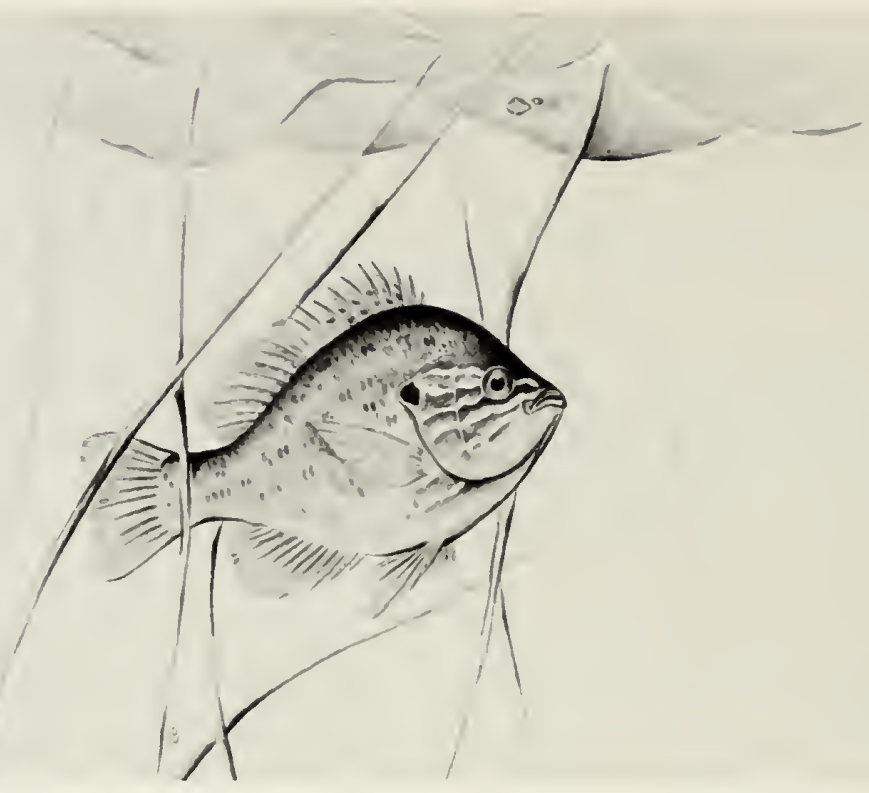

In Quetico pumpkinseeds seem rarely to exceed 6 or 7 inches in length, less than the 10 inches possible in most habitats in southern Ontario. They may live to be $8-10$ years of age. The data given here on the age-length relationship are province-wide averages, and only the minimum figures would apply in the park.

\begin{tabular}{lccccccccc}
\hline Age & 1 & 2 & 3 & 4 & 5 & 6 & 7 & 8 & 9 \\
\hline $\begin{array}{l}\text { Fork length } \\
\text { in inches }\end{array}$ & 3.5 & $4.2-6.0$ & $4.7-7.2$ & $4.8-8.2$ & $6.3-8.0$ & $7.0-8.7$ & $7.5-9.0$ & $8.7-9.1$ & $8.5-9.5$ \\
\hline
\end{tabular}

This sunfish eats a wide variety of bottom invertebrates and seems to prey less on fishes than the two preceding species. It is almost impossible to get a hook of any size baited with worms down to bigger fishes when pumpkinseeds are around.

This sunfish, like the others, has a rather protracted spawning season, peaking in early summer and sometimes lasting until August. The male builds a nest and at spawning time is very aggressive and territorial.

Although small, this species provides the fly-rod fisherman with ample diversion. Pumpkinseeds will take flies, poppers, and other small lures, and with light tackle the resistance of the deep body, once the fish is hooked, leads to a struggle for the angler. For the amount of food provided they are troublesome to scale and clean, but they are nonetheless delicious. If food is short, even a bent pin and earthworms, grubs, or other insects found under dead logs should soon yield a meal. 


\section{Bluegill-Lepomis macrochirus}

The bluegill, another compressed. deep-bodied sunfish, has a smaller mouth than the pumpkinseed, and a very long black earflap with no bright edge or spot. There is an obvious large black spot at the posterior base of the soft dorsal fin. All fins are blue-grey and without small spots. The overall upper body colour is green to brown. with several dark. but vague, vertical bars down the flanks. The belly is silver-white, and the breast yellow or copper-orange.

This species appears to occur only in the southern part of the park (see p. 58), except for one population in Jean Lake in the northwest. It was taken only in seven locations ( $3.6 \%$, ranks 25 th with three other species). The Quetico populations are the western limit of the natural Canadian distribution of the species.

There are too few records of this species from Quetico for an accurate concept of the relationship between age and length, but the following average figures for northern Wisconsin probably approximate the relationship in Quetico.

\begin{tabular}{lccccccccc}
\hline Age & 1 & 2 & 3 & 4 & 5 & 6 & 7 & 8 & 9 \\
\hline $\begin{array}{l}\text { Total length } \\
\text { in inches }\end{array}$ & 1.5 & 3.1 & 4.3 & 5.6 & 6.5 & 7.2 & 7.9 & 8.0 & 8.3 \\
\hline
\end{tabular}

The bluegill consumes a wide variety of food, including immature aquatic insects, molluscs, algae, and, less frequently, small fishes. When schools are near the surface, feeding bluegills try everything from woodchips to floating debris for edibility. Bare toes dangling from a canoe will also be nibbled.

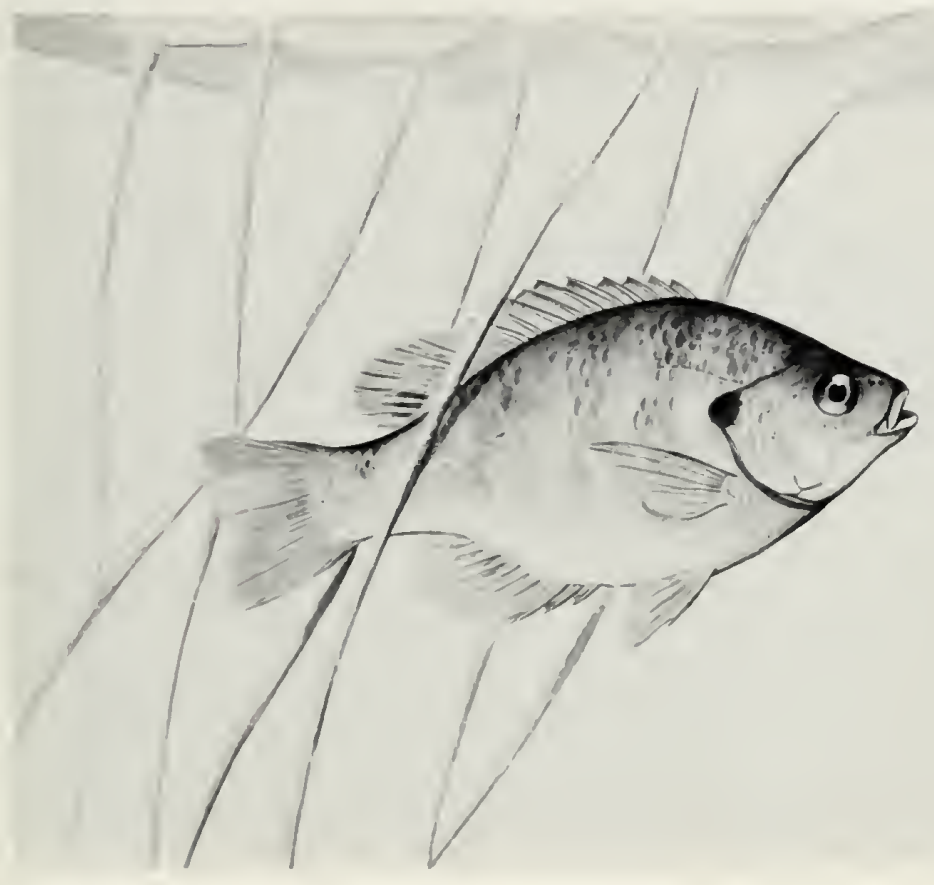


As with the other species, bluegills spawn in 1 or 2 feet of water and on a variety of bottoms, in mid-summer. Where they are abundant, their two-foot circular nests may almost touch, and there is much challenging and chasing in order to maintain territories.

Any of the sunfishes in the park will provide fine sport with ultra-light tackle and any small lure or fly. They are great fun for children and require nothing more than a tree branch, a 3-foot piece of string, a small hook, and a small piece of worm. Their ability to rob bait can try an angler's patience if he is still fishing with live bait for larger fishes.

\section{Longear Sunfish-Lepomis megalotis}

The longear is probably the smallest, most colourful, and prettiest sunfish found in Quetico. This fish is deep-bodied, compressed, and has a large eye, a small mouth, and a broad, upturned earflap with a black centre and yellow to red margin. The back and upper sides are rusty brown, the flanks reddish, and the sides and head mottled with orange and turquoise. The cheeks are orange with wavy blue radiating lines, the breast and belly are red to orange, and the fins orange or yellow. If not fully coloured, this species might be mistaken for the pumpkinseed, but the pectoral fin is very short and rounded, and individuals of any length have much larger earflaps than those of the pumpkinseed.

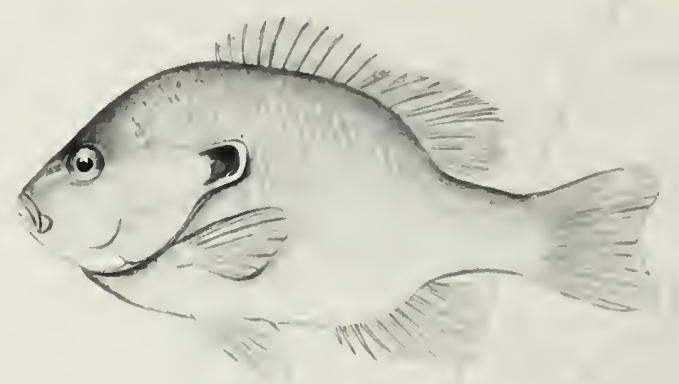


Like other sunfishes, this species appears to be found mainly in the south of the park. but it also occurs between Quetico and Sturgeon lakes (see p. 58). It was taken in only nine locations (4.6\%, ranks 24 th with the black crappie). Like the green sunfish, it is apparently more abundant in Quetico than in its other scattered areas of distribution in Ontario and Quebec.

In the park it occurs in the shallow's of large and small lakes and in quiet streams in or near aquatic vegetation.

The longear sunfish does not seem to grow in Quetico to more than 4 or 5 inches in length. which is the average size throughout its range. It is slowgrowing. as this maximum length may take 6-8 years to attain. as indicated by the following average data from Michigan:

\begin{tabular}{lcccccc}
\hline Age & 1 & 2 & 3 & 4 & 5 & 6 \\
$\begin{array}{l}\text { Total length } \\
\text { in inches }\end{array}$ & 2.2 & 2.9 & 3.9 & 4.5 & 5.5 & 5.5 \\
\hline
\end{tabular}

Longears, like some other sunfishes, are surface feeders and take mature insects and other invertebrates. Small fishes are also eaten.

This species spawns between late June and August, depending on water temperature. The males build nests and defend territories as the other sunfishes do.

Too small to be much of a sport fish, this species is a delight to behold.

\section{Smallmouth Bass-1/icroprerus dolomieui}

When these important sport fish were first captured in Quetico, anglers were often confused in attempting to distinguish them from the superficially similar largemouth bass. The smallmouth bass is actually a large member of the sunfish family. It is compressed and deep-bodied; the two dorsal fins do not appear almost separated; and the upper jaw extends to the middle of the eye only. The colour of the back and upper sides is green to bronze with yellow tints, and there are darker markings in the form of brown radiating lines on the head, and narrow vertical bars on the sides. The largemouth bass is greener in colour and has a larger mouth, and the dark markings form a long horizontal band. In their first summer smallmouth bass are readily identified by the conspicuous colours of the caudal fin. The base of this fin is bright amber to orange: then follows a narrower black band, and the tip of the fin is pale yellow to white.

The smallmouth bass is now widely distributed throughout the park (see $p$. 58 ) and was taken in 61 different locations $(31.3 \%$, ranks 6 th). This distribution may result from the combination of natural and introduced populations. 


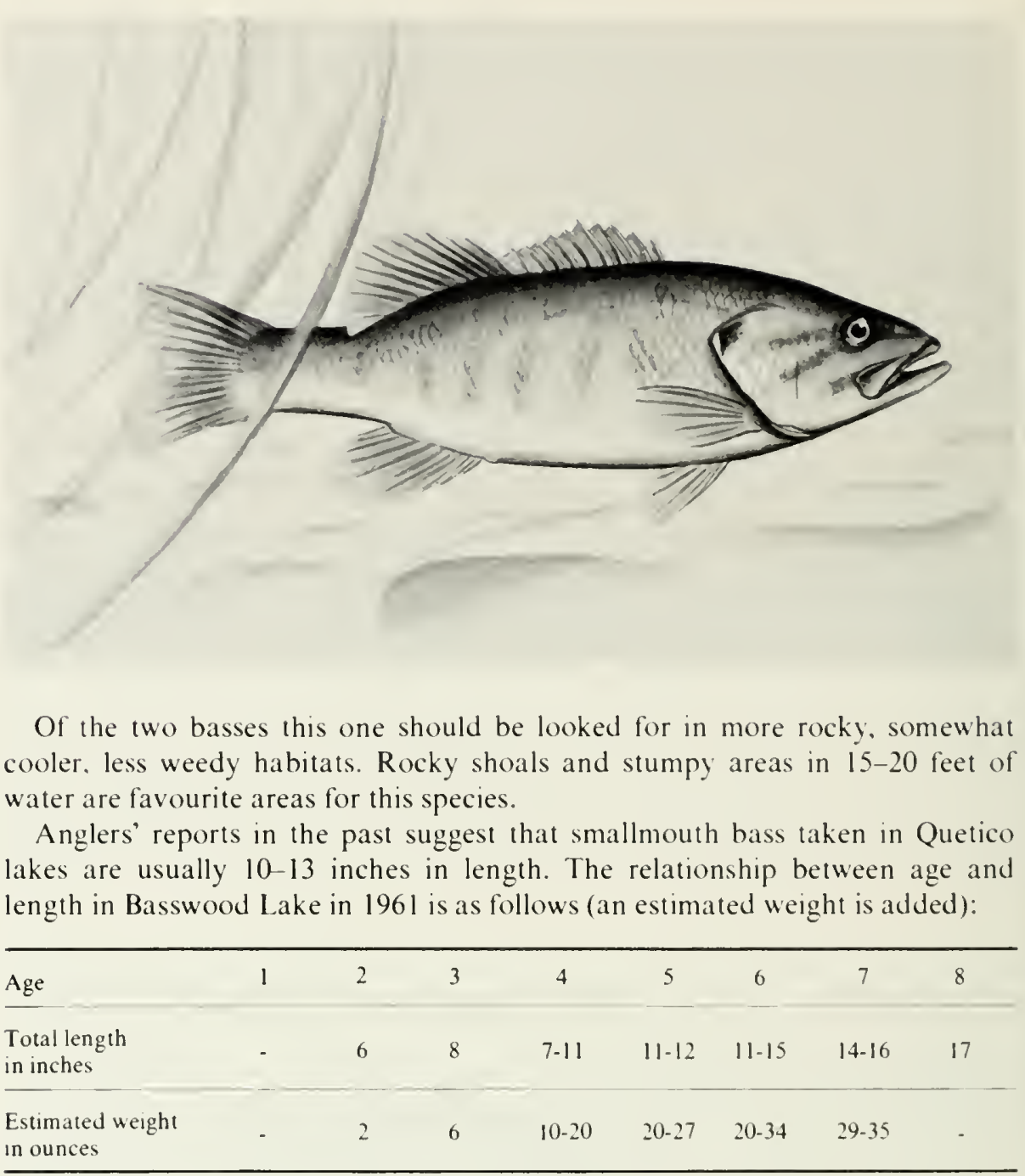

If the 1961 age interpretation was accurate, this is better growth, from age 4 onward, than in Lake Erie - a possibility which I question. What appears to be better growth in Quetico may simply reflect low angling pressure there. When we consider that the present North American record is a bass 27 inches long weighing almost 12 pounds, it is obvious Quetico bass are not large.

Smallmouth bass eat a variety of food. but when crayfish are available they seem to be the preferred ration. An examination of Quetico bass showed the following percent frequency of occurrence of various items: insects $46.5 \%$, crayfish $60.5 \%$, leeches $4.6 \%$, fishes $25.6 \%$ other material $9.3 \%$. Obviously crayfish and small fishes are the best bait for anglers to use.

These large sunfish spawn over a period of about a week in the late spring or early summer, depending on water temperature. In Quetico this is probably in June or early July. The male excavates, or cleans, a large circle of sandy, grav- 
elly. or rocky bottom to form a nest. Males defend their territory and are very aggressive at spawning time. They fan the eggs to aerate them, and for a short period guard the newly hatched young.

According to Scidmore et al. (1961) the spread of smallmouth bass through the park is probably the result of liberations in border lakes by the Minnesota Department of Natural Resources. These may have begun in 1941 in Basswood Lake. More fish were introduced in 1942 and 1946. None have apparently been introduced since. There is no record of this species having been liberated in the Canadian waters of Quetico, so the northward dispersal is a natural one. However. Eddy and Underhill (1974) stated: "It seems that the most successful stocking of the border waters resulted from the Canadian introduction" [1901. Long Lake near Kenora]. In 1941 smallmouth bass were known only from Point Lake south of Kahshahpiwi Lake. By 1946 "bass" were reported by anglers from 19 lakes in the south of the park, but the problem of identification at that time made it impossible to separate the two species in the reports. Now, 27 years later. the smallmouth has spread to 58 localities as far north as French Lake.

This is a species of great importance to the angler as it is normally easily taken with live bait or artificial lures and is a delight to eat.

\section{Largemouth Bass-Microplerus salmoides}

This large sunfish is not as important in Quetico as the closely related smallmouth bass. Like the smallmouth bass it is laterally compressed and deepbodied: but the two dorsal fins appear more separated than in the smallmouth

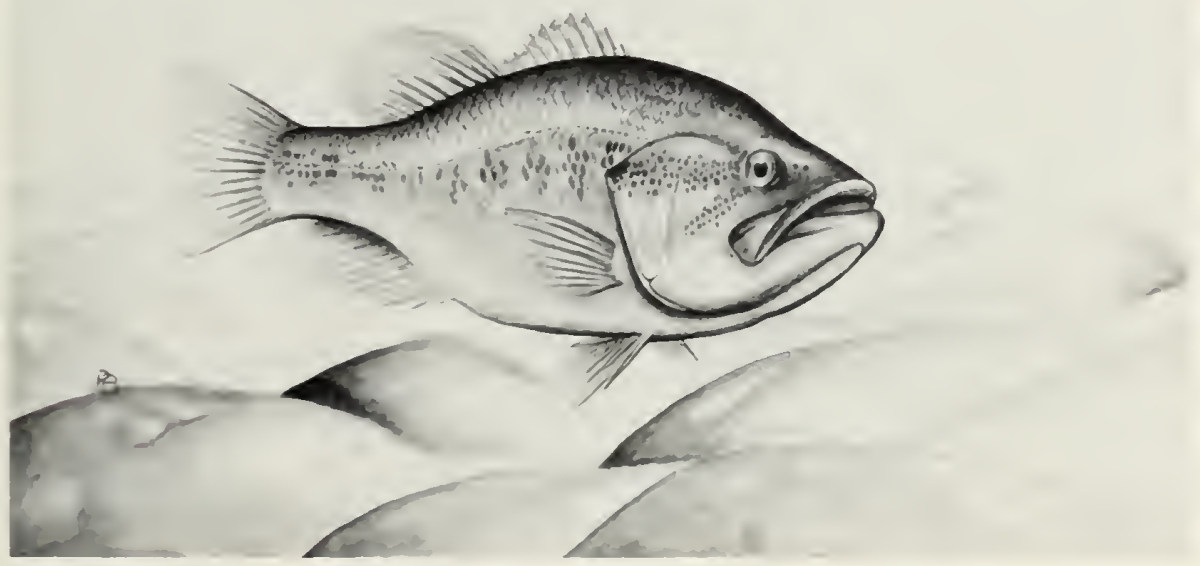


bass and the upper jaw extends to, or beyond, the posterior margin of the eye. The colour of the back and upper sides is pale to dark green or almost black. There are no radiating dark lines on the head, and the middle of each side is marked with a single, wide, horizontal black band, or squarish blotches resulting from the interruption of this band. The band is very prominent in the young. but the young of this species do not have bands of colour in the tail as do the smallmouth bass.

Largemouth bass, less widely distributed in the park. still occur mainly in the south and are moving north more in the western part of the park (see p. 58). This species was captured at 32 locations (16.4\%, ranks 13th). Its presence in Quetico is the result of natural northward spread from introductions in the Boundary Waters.

This species is characteristic of warmer, shallower, weedy, stump-filled areas. Where there are water lilies, in water $8-15$ feet deep. there are usually largemouth bass. The upper levels of smaller, shallower lakes and shallow, weedy bays of larger lakes are the places to look for them. This species is rarely taken deeper than 20 feet.

There are little or no data on the growth of this bass in Quetico, but the average relationship between age, length, and weight for Ontario, given below, can be used as a guide.

\begin{tabular}{lcccccccccccccc}
\hline Age & 1 & 2 & 3 & 4 & 5 & 6 & 7 & 8 & 9 & 10 & 11 & 12 & 13 \\
\hline $\begin{array}{l}\text { Total length } \\
\text { in inches }\end{array}$ & 6.7 & 8.7 & 11.3 & 12.6 & 13.7 & 15.4 & 16.8 & 17.7 & 18.0 & 19.3 & 18.2 & 19.8 & 21.0 \\
\hline $\begin{array}{l}\text { Weight in } \\
\text { pounds }\end{array}$ & 0.1 & 0.5 & 1.0 & 1.1 & 1.5 & 2.5 & 3.2 & 3.2 & 3.9 & 4.0 & - & 6.3 & - \\
\hline
\end{tabular}

In general the largemouth bass taken by anglers in Quetico average 8-15 inches in length and from $1 / 2$ pound to 2 pounds in weight. This species has been known to grow to 14 pounds in Ontario. The North American angling record is $32 \frac{1}{2}$ inches and $22 \frac{1}{4}$ pounds.

The diet of the largemouth is made up largely of other fishes, but includes frogs, crayfish, and immature forms of aquatic insects, such as dragonflies. This fish takes much of its food at or near the surface and consequently is a good quarry for the enjoyable angling technique of surface plug-casting.

Like the smallmouth bass, this species spawns from spring to early summer. Spawning time in Quetico is probably late June and early July. The male digs or clears a rather large, shallow nest in the soft bottom among vegetation or near the protection of submerged logs or stumps, and protects it pugnaciously against all intruders. The male fans the eggs, and for a time shepherds the newly hatched young.

This species is another of the angler's delights. A large minnow or a frog cast into the vegetation or used to still fish at the edges of weeds should provide success. The enjoyment of trying your casting skill with surface lures among vegetation and stumps on a calm evening is great, regardless of the success. The 
splashing strike of a largemouth bass under those conditions is a thrill and your catch a taste-treat of flaky, white, sweet flesh.

Like the smallmouth bass. the largemouth bass owes its presence in Quetico to introductions in the Border Waters in 1945. Early captures of the two forms were confused, so early records cannot be trusted.

\section{Black Crappie-Pomoxis nigromaculatus}

This is the only representative of the third group of sunfishes known in the park - the crappies. Crappies are often known as strawberry bass, or calico bass. The black crappie is a very deep-bodied and strongly compressed fish, with a highly arched back, a pointed snout, a prominent depression over the eye, and a prominently marbled green to golden brown body. The fins are dark and are characteristically marked with yellow to green spots. The crappie is readily distinguished from other sunfishes by its disc-like body, its colour, its lack of prominent earflaps. its 8 , rather than 10 or 11 . dorsal spines, and its 17 anal soft rays compared with 8-12 in the other smaller sunfishes.

Except for its presence in Cirrus Lake, the black crappie is restricted to the Boundary Waters (see p. 59). It was taken in nine localities $(4.6 \%$, ranks 24 th with the longear sunfish).

Crappies are usually found in the clear, cooler water of deeper ponds, small lakes, and bays of larger lakes, and in the slow-flowing portions of large rivers. They have been found in or near extensive growths of vegetation and over gravel bottom. They move to deeper water in the warm part of summer.

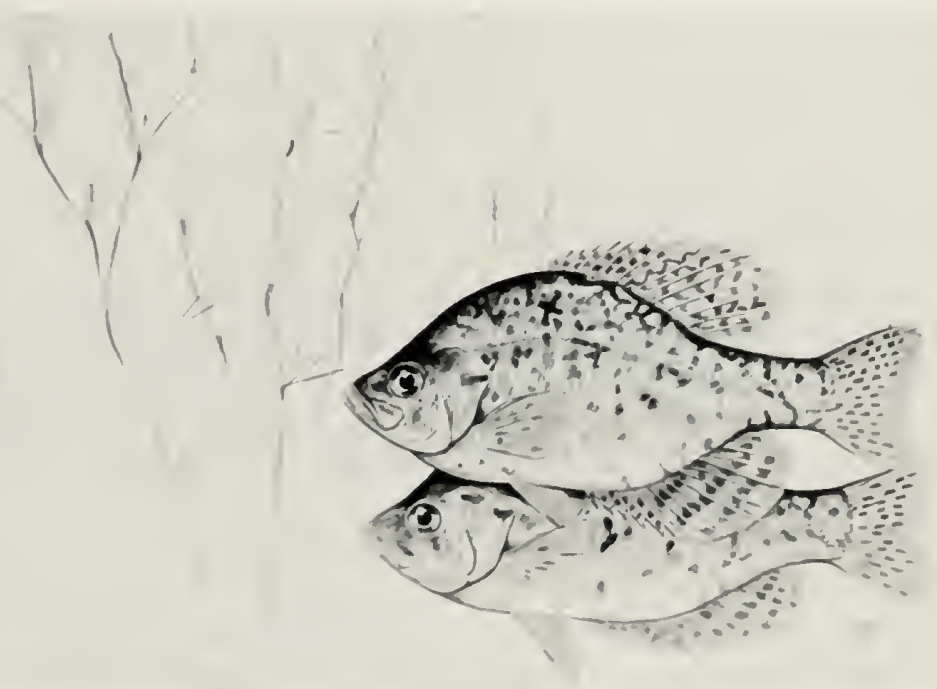


Anglers usually catch crappies 7-10 inches long. At this length this fish is almost as deep as it is long. In the southern U.S. this species grows to 19 inches and 5 pounds, the angling record. The relationships between age, average length, and weight for nearby Lake of the Woods approximate those in Quetico.

\begin{tabular}{lccccccccc}
\hline Age & 1 & 2 & 3 & 4 & 5 & 6 & 7 & 8 & 9 \\
\hline $\begin{array}{l}\text { Fork length } \\
\text { in inches }\end{array}$ & 4.4 & 6.6 & 8.4 & 10.0 & 10.5 & 11.1 & 11.4 & 12.0 & 12.5 \\
\hline $\begin{array}{l}\text { Weight in } \\
\text { pounds }\end{array}$ & 0.1 & 0.1 & 0.4 & 0.7 & 0.7 & 0.9 & 1.0 & 1.1 & 1.3 \\
\hline
\end{tabular}

Crappies consume a variety of food, including aquatic insects, crustaceans, and other fishes. Food is usually taken in the open water offshore, mainly in the early morning and from near sunset to after dark. Larger crappies feed primarily on other fishes.

This species probably spawns in the park in June and early July. The males clear shallow nests in sand. gravel. or soft bottom in shallow water. Like other sunfishes they guard the nest, fan the eggs, and protect the young.

This is a sport fish of considerable interest in certain areas. It is a schooling species, and when a school is encountered many can be readily taken with worms. small bait fishes, or small lures and light tackle. Black crappies are active in winter and so are a good species for ice fishing. They are very good to eat.

Old notes and correspondence at Row suggest that in 1911. II cans of "croppies" $1 \frac{1}{2}$ inches long were planted in Lac la Croix, and that Minnesota introduced this species in border lakes about 1944, but Canadians were destroying them as undesirable.

\section{Yellow Perch-Perca flavescens}

This well-known fish is distinguishable from other fishes by a number of characters. The body is rather deep. The back is green to brown, the sides yellowgreen, and the belly milky white. There are 4-7 wide dark bars extending down the sides from the back. The lower fins are often orange to red. There are two dorsal fins, and the anterior, larger one is supported by sharp spines. There are also sharp spines in the anal and pelvic fins.

This species occurs widely throughout the park (see p. 59) and was taken in 68 locations $(34.9 \%$, ranks 5 th).

Yellow perch occur in a wide variety of habitats in both rivers and lakes. Typically a shallow-water species, they are usually in the top 30 feet but are known to go deeper elsewhere. 


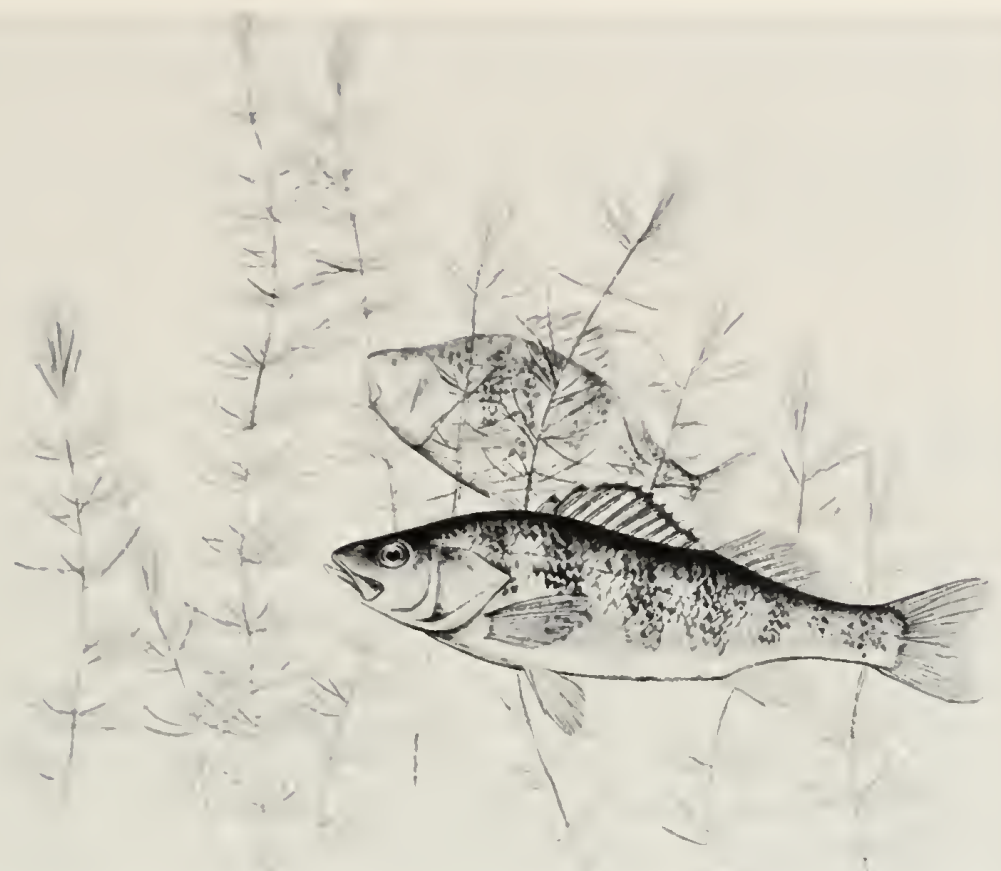

In Lac la Croix vellow perch taken in nets ranged from 5 to $9 \frac{1}{2}$ inches in length. which is also the size usually caught by anglers. Individuals up to 12 inches in length may be seen. This species has been recorded as large as 4 pounds in Quebec, and the angling record is 4 pounds $3 \frac{1}{2}$ ounces, from New Jerse!.

The following figures from Manitoba probably approximate the relationship between age and average size for yellow perch in Quetico.

\begin{tabular}{lccccccccc}
\hline Age & 1 & 2 & 3 & 4 & 5 & 6 & 7 & 8 & 9 \\
\hline $\begin{array}{l}\text { Fork length } \\
\text { in inches }\end{array}$ & 1.9 & 2.8 & 3.4 & 4.9 & 5.6 & 6.7 & 8.4 & 9.1 & 11.9 \\
\hline
\end{tabular}

Yellow perch feed in the morning and evening on a wide variety of food, including most aquatic invertebrates, fish eggs, and other fishes. Food is taken over the whole range of depths of the habitat, including the bottom, but it is unusual for yellow perch to take food at the surface.

This species spawns in the early spring, but in the park spawning may extend into June. The adults move into shallower vegetated water, but no nest is built. The eggs are shed in a gelatinous, accordion-folded tube. No other species in Canada is known to lay its eggs in this way.

Yellow perch occur singly or in schools, often congregating near shore in large numbers in the spring. They will take such bait as worms, minnows, or cut bait. and greatest success is usually achieved by still fishing off the edges of 
shoals. This is one of the species most frequently taken when fishing through the ice. The flesh is delicious, and fillets can easily be prepared even from rather small perch. The black-spot and yellow grub parasites seen regularly on this species cannot be transmitted to man; they are killed by proper cooking and in no way render the fish inedible.

\section{Sauger-Sizostedion canadense}

This member of the perch family is very difficult to distinguish from the far more common and abundant walleye, and casual visitors to the park have probably confused the two. Its body is cylindrical, and is less compressed and less deep than that of the walleye. There are two dorsal fins. The first, which has sharp spines, is marked with two or three rows of small black spots, but there is no black blotch at the posterior base. The lower tip of the caudal fin is usually similar to that of the upper, not prominently white. The body is usually olive to brown rather than yellow-green, and has several wide vertical bars and some round spots larger than the eye. These markings are often inconspicuous on fish from clear water.

The sauger is at present known positively only from Lac la Croix. It has been reported from Pickerel Lake (ranks 30 th with two other species). It should be watched for in other southern boundary waters and, if caught, should be turned in to the Ministry of Natural Resources, as sight identity by anglers is inadequate to confirm its presence.

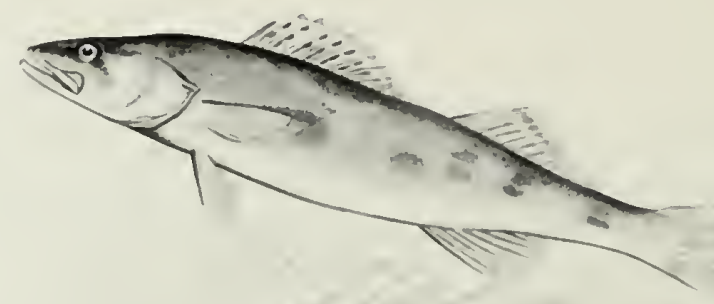


In general the sauger seems to prefer large, shallow, turbid lakes or warm, turbid baly of lakes. In this type of habitat it seems to be more successful than the walleve.

Salugers taken in nets in Lac la Croix were from 8 to 14 inches in length. 1his species grows more slowly than the walleye but in some areas lives longer. In Lake of the Woods $i t$ is known to reach 15 inches and $1 \frac{1}{2}$ pounds, at which size the fish is about 10 years of age. The angling record is a fish 28 inches long weighing 8 pounds 5 ounces, from Nebraska.

Spawning takes place outside the park from late May to early June.

Although smaller than the walleye, the sauger has the same sport characteristics and is a choice food fish. Angling methods suitable for the walleye should capture this species as well.

\section{Walleye (or pickerel)-Stizostedion vitreum}

This species, more often known to residents of Ontario as pickerel or yellow pickerel. is the most important species of fish in Quetico Provincial Park. Like the yellow perch and sauger, it is a member of the perch family, and has a long. cylindrical. somewhat compressed body, and a large mouth well armed with teeth. There are two dorsal fins, the first with very sharp spines. There are no small dark spots on the spiny dorsal, but there is a large dark blotch at the posterior base. The lower tip of the caudal fin and the tip of the anal fin are conspicuously white. The body is green to olive on the back, yellow on the sides,

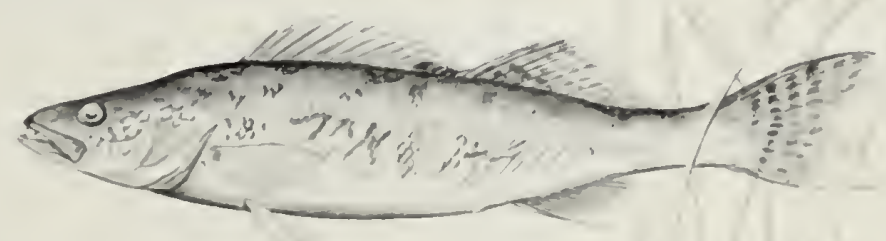




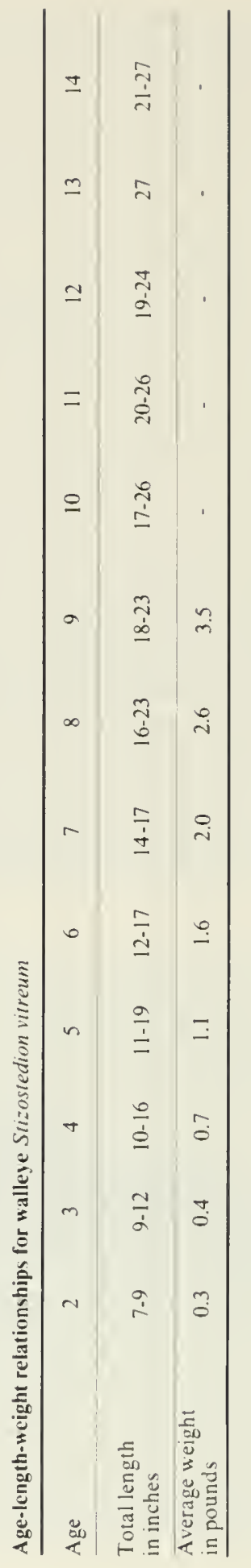


and white below. There are short, dark, sertical bars on the upper sides, but these are inconspicuous in large fish.

The species is common throughout the park (see p. 60) and is second only to northern pike in frequency of occurrence. It was taken from 123 localities (63.1\% ranks 2 nd). Walleyes are more common in lakes, but they were taken in rivers as well. They can often be found near vegetation or stumps, in 10-20 feet of water.

Anglers in Quetico usually catch walleyes between 12 and 18 inches long, but surveys indicate that they occur up to 30 inches long in Basswood Lake. The figures for Pickerel and Basswood lakes, given on page 30, indicate the relationship between age and size in the park.

For Pickerel Lake. the average lengths in inches for fishes 2 to 9 years old are $9.0,10.3,12.3,14.6,15.7,17.5,20.0,21.5$. The angling record for this species is a fish caught in Tennessee which was 41 inches long and weighed 25 pounds.

Even as adults. walleyes eat a variety of food, and insects can constitute almost half the ration of fish of the size caught by anglers. The largest part of their food is made up of other fishes-including walleyes, if other species are scarce.

Walleyes spawn in the park from May to early June, when they move on to shallow, rocky areas or into swift rivers of moderate size. Spawning takes place at night. and no nest is built.

This species, like the yellow perch and sauger, usually occurs in schools, and where one is caught there are usually others present. Still fishing with minnows, trolling with artificial lures and worms, or casting sinking plugs are the best angling methods. Walleyes are well adapted to low light intensities, and this special visual adaptation makes them seek shelter in bright sunlight. The best angling is during the early morning and evening feeding periods. During the day they should be sought near areas of vegetation which provide shade. Walleyes are active in winter, and fishing through the ice with minnows is usually successful where they are abundant. This species is probably the prime food fish of the park, since the trouts are far less available. In fact, it is said that one can tolerate a steady diet of this delicious but less rich fish longer than a diet of the trouts.

Old records at the ROM mention that "Americans planted this species in Saganaga Lake in August 1944". 

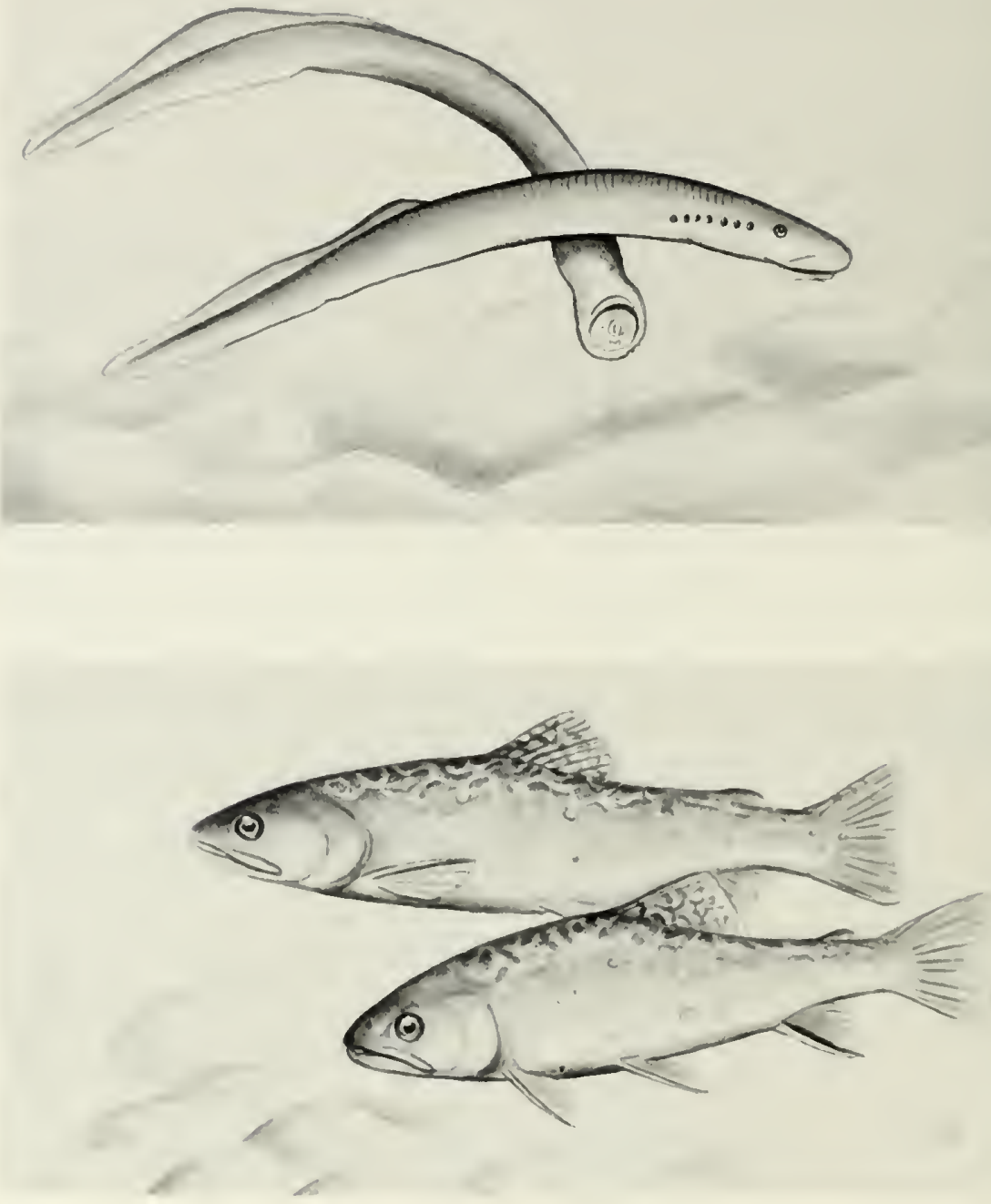


\section{SPECIES ACCOUNTS}

\section{Other Fishes}

\section{Silver Lamprey-Ichthyomyzon unicuspis}

This is the only lamprey known to occur in the park. Lampreys are often confused with the American eel. However, the silver lamprey has a circular buccal funnel with no true jaws, and seven round external gill openings behind each eye.

It is at present known only from five southern lakes $(2.6 \%$, ranks 27 th with the trout-perch). In 1974 it was also recorded from Lonely and Kawnipi lakes, where it was found attached to northern pike.

The silver lamprey inhabits large lakes and rivers. Unless seen in spawning streams in the spring. it will probably be encountered only if one catches a fish to which a parasitic adult is attached.

The adults live only 12-20 months and never exceed 13 inches in length.

Adult lampreys are edible. The young are useful as bait, but such use is illegal in Ontario.

\section{Brook Trout-Salvelinus fontinalis}

The brook trout and the lake trout are the only trouts at present known to occur in or near the park. The brook trout is distinguished from the lake trout (and most other species) by its overall green to brown colour, bright red belly, reddish lower fins, and square tail, and by the presence on the flanks of at least a few small red spots with blue haloes around them.

This popular trout is rare in the park. It is at present known to occur there only in Hop Lake, which is tributary to Windigoostigwan Lake. It also occurs nearby, but outside the park, in Jump Lake near Batchewaung Lake.

In clear. cool streams and lakes, the species can grow to 15 inches or more. but when found in the dark waters of beaver ponds, it may not exceed 6-8 inches. In lakes it may occur at least as deep as 25 feet.

Brook trout feed on a wide variety of insects and other invertebrates, but larger individuals take fishes as well.

Spawning takes place in late fall in streams or on the gravelly shores of lakes. 
34

QL HTICO FISHES
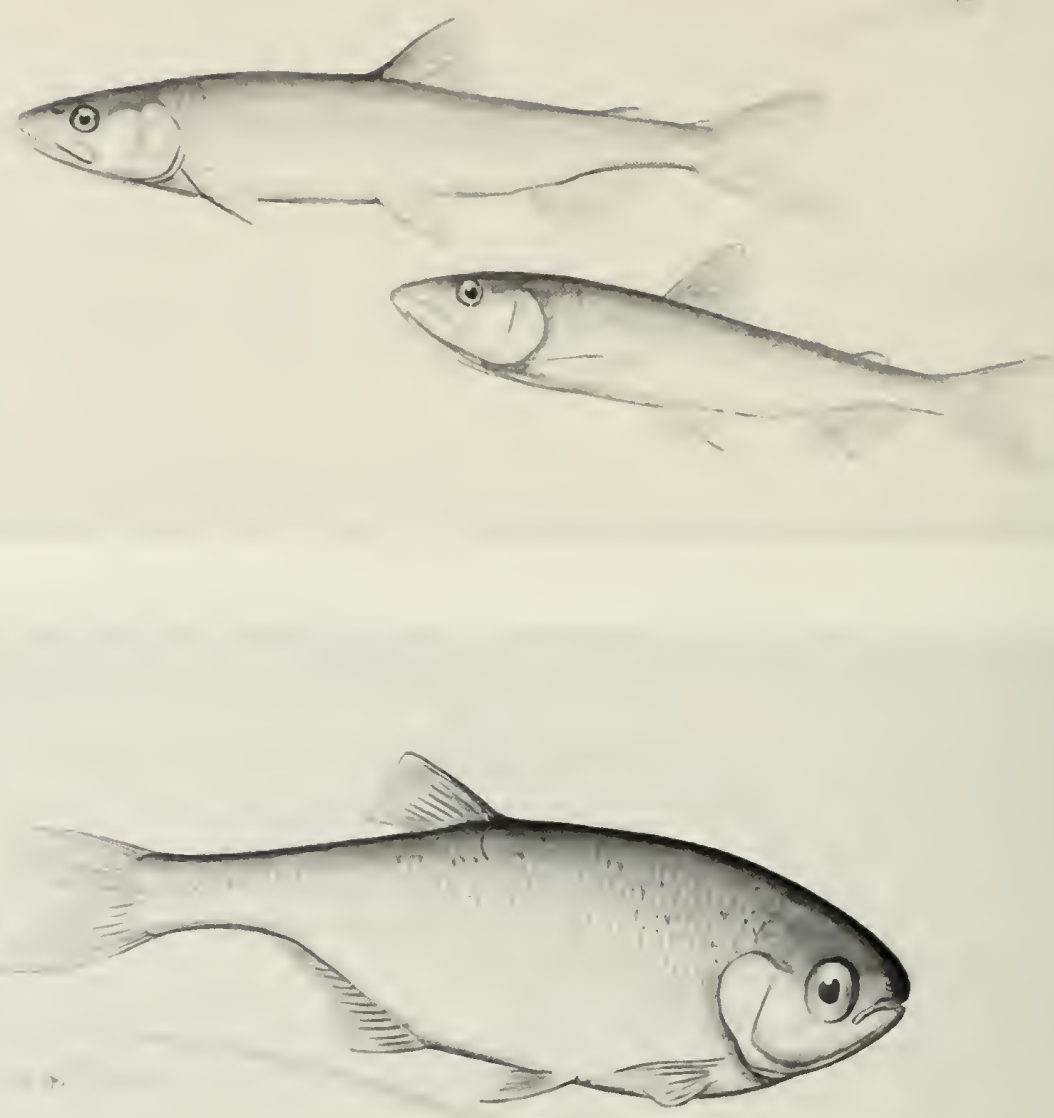


\section{Rainbow Snelt-Osmerus mordax}

This species is at present known only in Eva and French lakes. The smelt was first reported in 1972. frorin the stomach of a lake trout from Eva Lake. It should be watched for in water connected to French Lake and, if discovered, its presence should be reported.

This small (4-8 inches). cylindrical. silvery fish with an adipose fin is easily recognized by the enlarged, recurved teeth on the tip of the tongue.

The rainbow smelt is a lake species but runs into streams and onto beaches during spring nights to spawn. During spawning concentrations, large numbers can be taken at night with a dip net or, by special licence. with a short seine. When fresh, smelt have an odour like cucumbers and are very good to eat.

\section{Mooneye-Hiodon tergisus}

This species. usually $10-12$ inches in length, is compressed, deep-bodied, silvery to brown. and somewhat herring-like. It is readily identified by its short rounded snout and very large yellow eyes. and by the long base of the anal fin.

The mooneye is at present known only from the Wawiag River $\left(48^{\circ} 25.5^{\prime} \mathrm{N}\right.$, $91^{\circ} 01^{\prime} \mathrm{W}$ ) near the eastern border of the park. where it was taken by an angler in July 1973.

Mooneye can reach 17 inches in length. 2 pounds in weight, and 8 years of age.

The mooneye spawns in spring (May to early June), and large numbers of spawners migrate from lakes up large, clear streanıs.

This is not an important sport fish, but it will take a variety of small lures and flies. It is not generally considered a prime eating fish but is greatly improved by smoking.

\section{Central Mudminnow-Umbra limi}

This small species, in spite of its name, is not a minnow but a member of the group of fishes to which the northern pike belongs. It is dark green to brown in colour. has a short snout, a stubby, rounded body, a rounded tail, and usually a prominent black vertical bar at the base of the tail.

It is at present known only from Basswood and Bart lakes (1.0\%, ranks 30th with two other species).

Mudminnows will be found only on the silty bottom of quiet ponds, slow streams. and quiet bays of larger lakes. They are usually $2-3$ inches in length. will not exceed 4 inches, and live only about 4 years.

Even though mudminnows are abundant they may be inconspicuous, since they dart quickly into the loose bottom silt when disturbed.

Mudminnows are a hardy species and their ability to gulp atmospheric oxygen enables them to live in somewhat stagnant habitats. They are sometimes used as bait for larger fishes. 

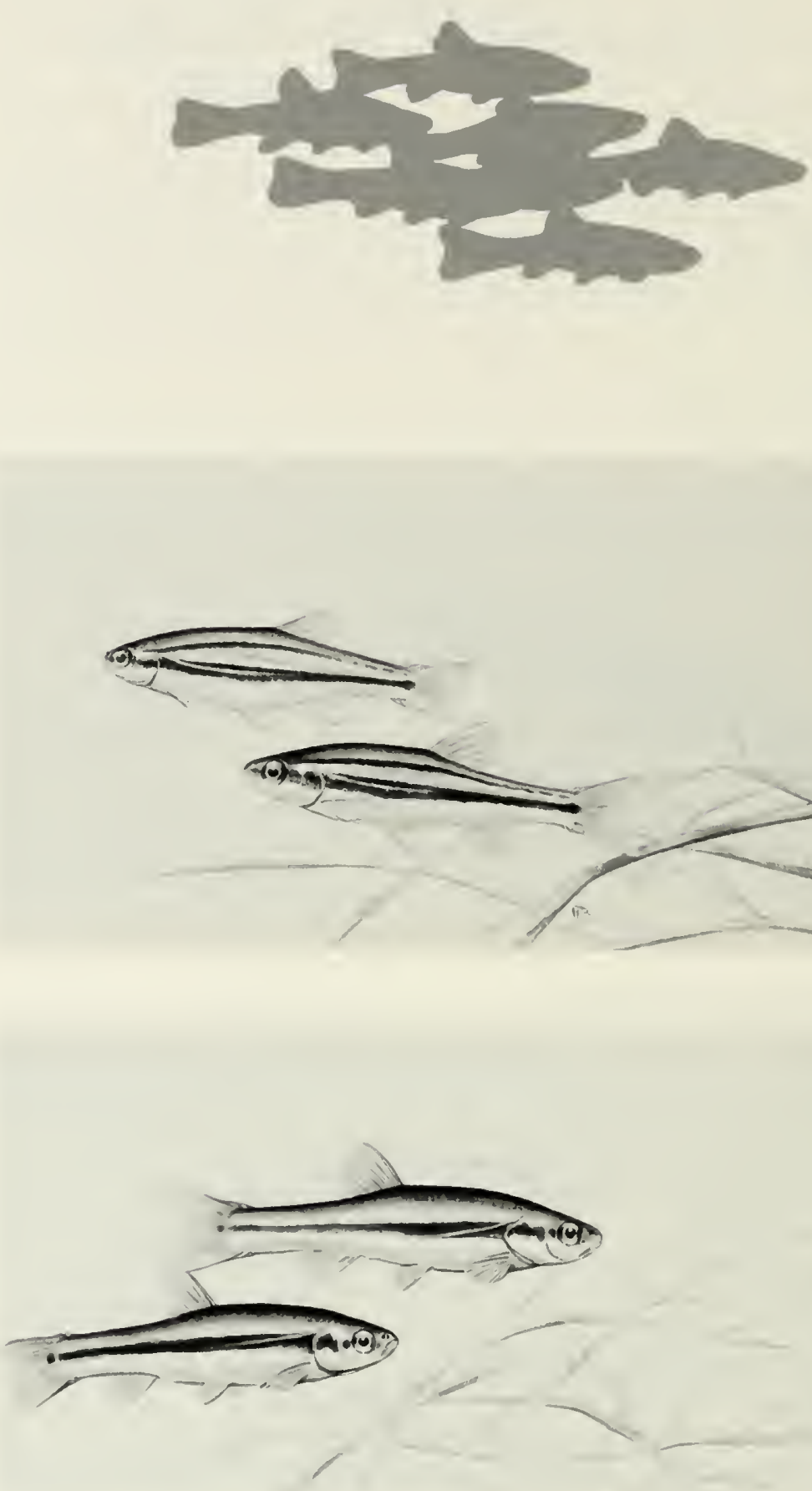
The nev 16 species are all minnows, even though some have common names such as shiner and chub. They are menbers of the family Cyprinidae. and although minnows in North America generally do not exceed 6 inches in length. larger species like the carp are members of this group. The term "minnow" should not be used for all small species nor for the young of all fishes. though sadly enough. it has crept into the accepted conmon names of fishes that are not minnows (e.g.. central mudminnow). All minnows are edible, and sometimes numbers of them can be easily captured in streans with a little ingenuity and a shirt, some evergreen boughs, or a boulder dam. North Americans are so inclined to separate fishes into food fishes and trash fishes that inexperienced people short of food might easily pass up this ready source.

\section{Northern Redbelly Dace—Chrosomus eos}

This is a rather small, robust minnow with an almost circular cross-section and a rather broad head. The scales are very small and inconspicuous. Redbelly dace have the general appearance of being dark olive to dark brown to the level of the eve. The upper sides have two horizontal dark bands. The area below the lower band is sometimes silvery, but more often yellow or brilliant red. This species is readily confused with the finescale dace, but the latter has a deeper head, and only one prominent black lateral line ending at the tail in a small spot.

The northern redbelly dace is usually about 2 inches in length. lives about 5 years, and occurs in dark boggy lakes, creeks. and ponds, or boggy bays and backwaters of lakes, over a bottom of detritus or silt.

This species has been taken in 18 Quetico lakes (see p. 55) mainly in the south and western areas of the park $(9.2 \%$, ranks 20 th $)$.

\section{Finescale Dace—Chrosomus neogaeus}

This minnow is small, stout, and round in cross-section, and has a large, broad head. The scales are small and inconspicuous. Like the northern redbelly dace it is generally dark on the back and upper sides. There is a single dark, horizontal lateral band starting on the snout and ending in a small spot at the base of the tail. The area below the lateral band is silvery in the young and yellow or bright red in breeding adults. The finescale dace is difficult to distinguish from the closely related northern redbelly dace but lacks the upper, narrower, lateral band of that species.

The finescale dace averages 3 inches in length. lives about 5 years, and inhabits boggy, dark waters over a bottom of silt or detritus. $1 t$ is often found with the northern redbelly dace.

This species was taken in 17 Quetico lakes (8.7\%, ranks 21 st). See p. 55. 

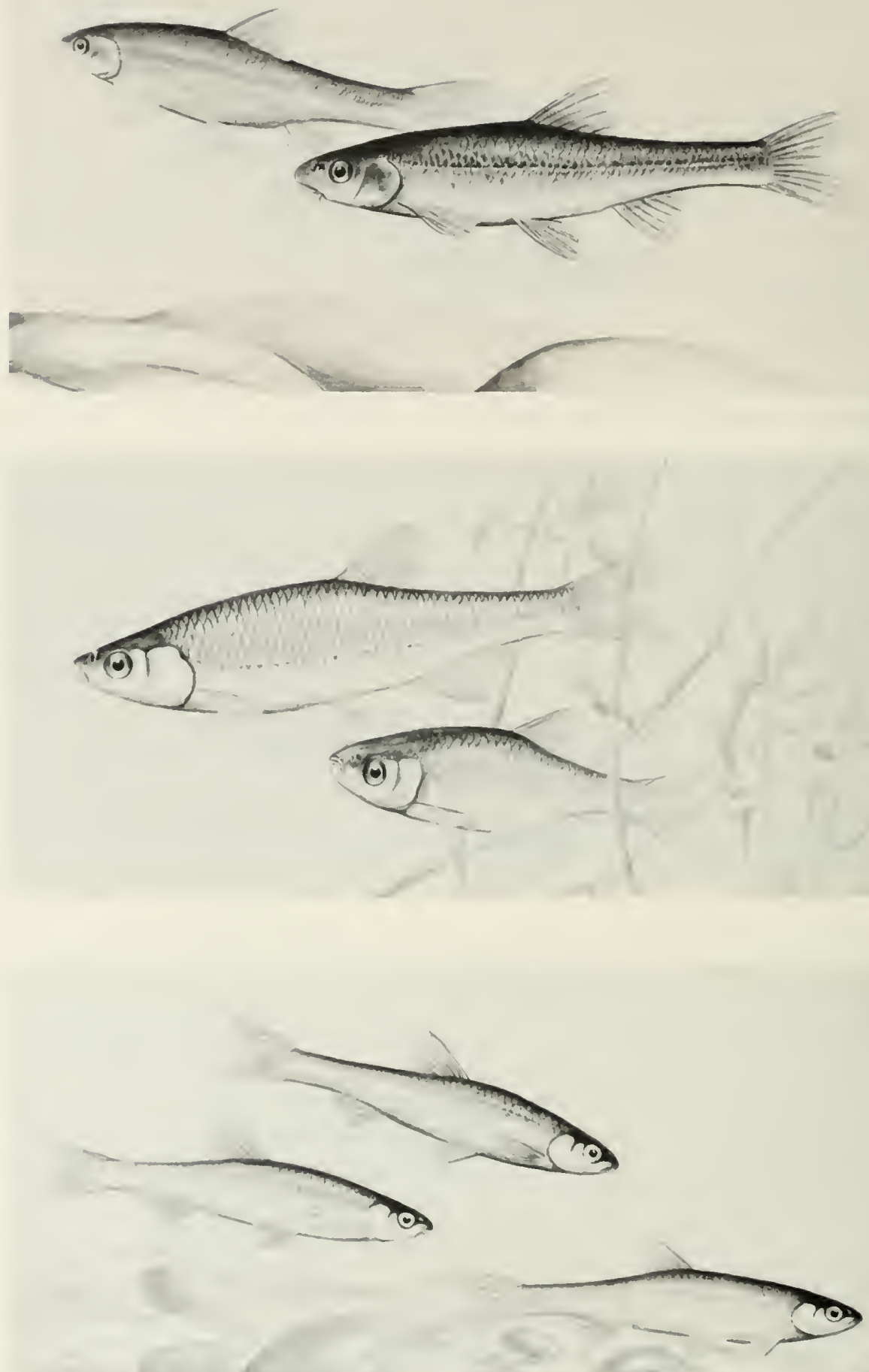


\section{Lake Club-Conesius plumbers}

This is one of the larger of the minnows in the park, averaging 4 inches in length. The body is moderately deep but rounded. The snout is long and rounded. extending over the upper jaw, the mouth large. the caludal peduncle long and slender. There is an inconspicuous barbel at both corners of the mouth. The scales are visible, and scattered single scales are darker than others. This species is generally dark above and silvery to lead-coloured below. Often there is red at the base of the pectoral and pelvic fins, at the corners of the mouth. and below the eye.

The lake chub can grow to 8 inches in length. It is considered a lake species. but it also inhabits large rivers.

Lake chub are at present known in Quetico only from the Cache River in the northeast part of the park, and so they rank last with a number of other species.

\section{Golden Shiner-Votemigonus crisolencas}

This minnow has a deep, laterally compressed body with a moderate arch to the back, a small. somewhat upturned mouth. a pointed snout. and a large bright eye. The anal fin has a moderately long base. The obvious lateral line is low and curved and follows the lower contour of the body. The young are grey to silvery. but adults are usually shiny gold.

The golden shiner lives from 5 to 8 years and elsewhere can attain a length of $8-10$ inches. It is a fish of clear, weedy, quiet, shallow water and prefers the open water of lakes to streams.

This species has been taken in 14 locations in Quetico (see p. 56). all of them lakes. and almost all in the general area of Quetico Lake. except for Louisa Lake $(7.2 \%$. ranks 22 nd with the pumpkinseed).

The golden shiner is an excellent bait minnow.

\section{Emerald Shiner-Votropis atherinoides}

This species is long. slender, and laterally compressed. It has a small head with rather large eyes and a moderately large mouth. The silvery scales are conspicuous and are easily dislodged. Emerald shiners are a brilliant silver colour, with blue-green or green iridescence. The young are practically transparent, and adults nearly translucent. There is a prominent black lateral band, but this is not conspicuous when the fish is alive.

Emerald shiners in the park are usually $2-3$ inches in length but can reach 4 inches. Large schools inhabit lakes and large rivers, remaining offshore in summer, but congregating in packed groups near shore in the fall.

The emerald shiner is presently known only from three widely separated lakes-Quetico. Darky, and French (1.5\%, ranks 29th).

This species is a favourite bait fish, as its large congregations make it easy to capture. It is the pickled, frozen, or salted minnow of the ice fishery. 

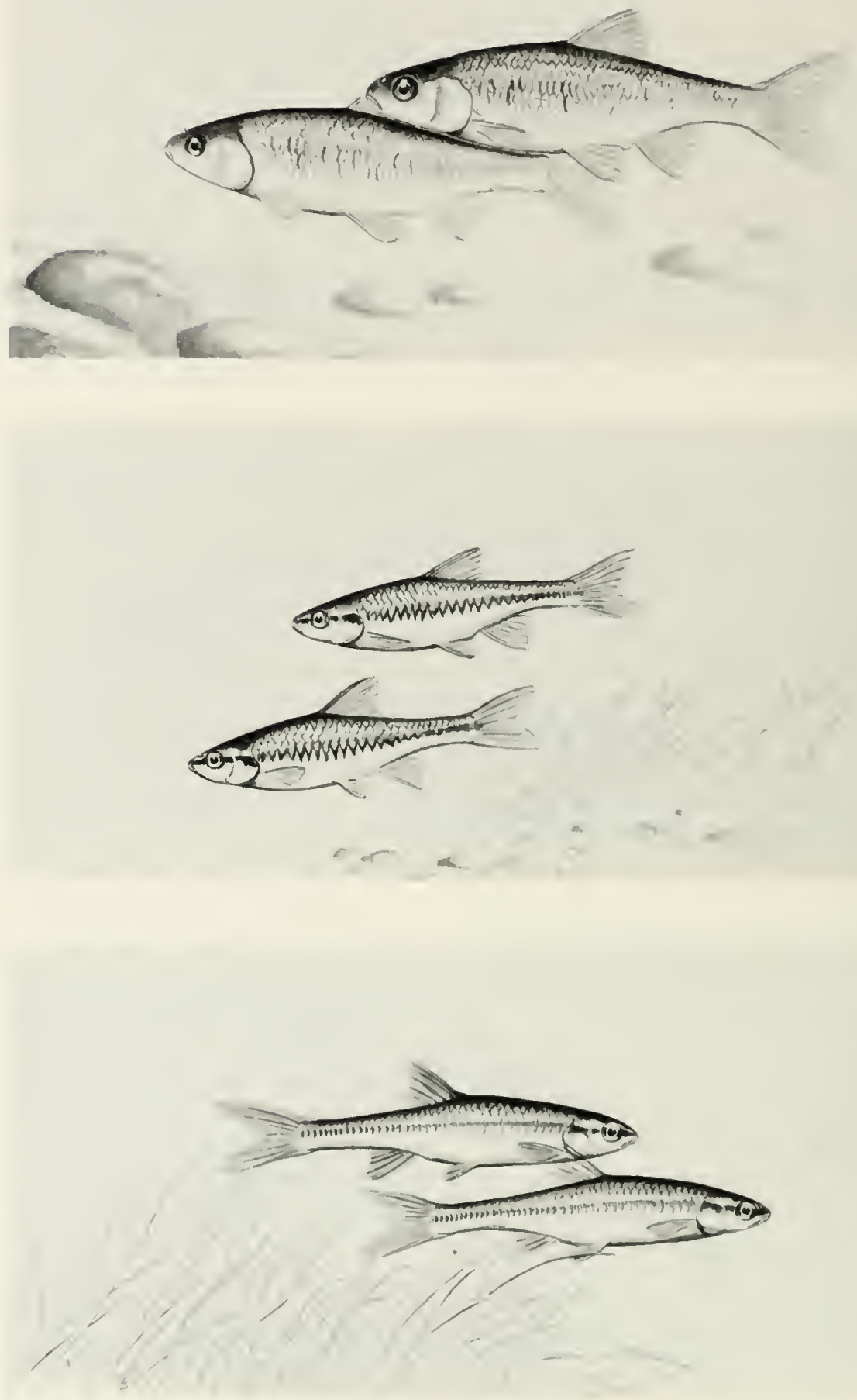


\section{Common Shiner-Notropis cormutus}

The common shiner, which is usually $2-4$ inches in length, has a stout, broad, laterally compressed body and a rather large head with a long, bluntly pointed snout. The scales are large, are higher than they are wide, and have the appearance of being separated at their posterior edges. General colouration is silvery with bronze iridescence, but the back is olive with a dark stripe. In large spawning males the head is dark, the body and fins are red, and there are prominent tubercles on the head and back.

This conspicuous species lives and feeds near the surface in clear lakes and streams. Common shiners can grow to 7 inches and are one of the larger minnows.

Despite its name, this is not the commonest minnow in Quetico. It was taken in 20 lakes and streams (10.3\% ranks 18th) and is widely distributed (see p. 56).

\section{Blackclin Shiner-Notropis heterodon}

This small but robust minnow is almost as wide as it is deep. The smallish head is bluntly pointed, the snout short, and the mouth small, but the eye is rather large. Fishes of this species rarely exeed $2 \frac{1}{2}$ inches in length. They are silver to yellowish above and white below, and are distinguished by a dark zigzag lateral band. which extends across the head, eye, and snout and onto the chin, as the name implies. The black chin helps to distinguish this species from the very similar blacknose shiner.

Blackchin shiners should be looked for only in the clear water of weedy, quiet pools of streams. or in similar inshore waters of lakes.

In Quetico the species has been seen in only seven lakes and streams (see p. 56). mainly in the south-southeast but also in one location north of Sturgeon Lake $(3.6 \%$, ranks 25 th with three other species).

\section{Blacknose Shiner-Notropis heterolepis}

This minnow is, in general. very similar to the blackchin shiner in body shape and in overall colouring. However, the dark lateral band is less conspicuous and on the anterior part of the body is composed of a series of vertical crescent marks. The band continues across the head onto the snout but not onto the chin.

Blacknose shiners are found in the shallow water of slow streams and clear, weedy bays, over sand or gravel bottoms. They average $2 \frac{1}{2}$ inches in length but can reach almost 4 inches.

This species is widely distributed in Quetico, much more so than the closely related blackchin shiner (see p. 56). It has been taken in 37 locations, mostly lakes $(19.0 \%$, ranks II th with the mimic shiner). 
42 QUETICO FISHES
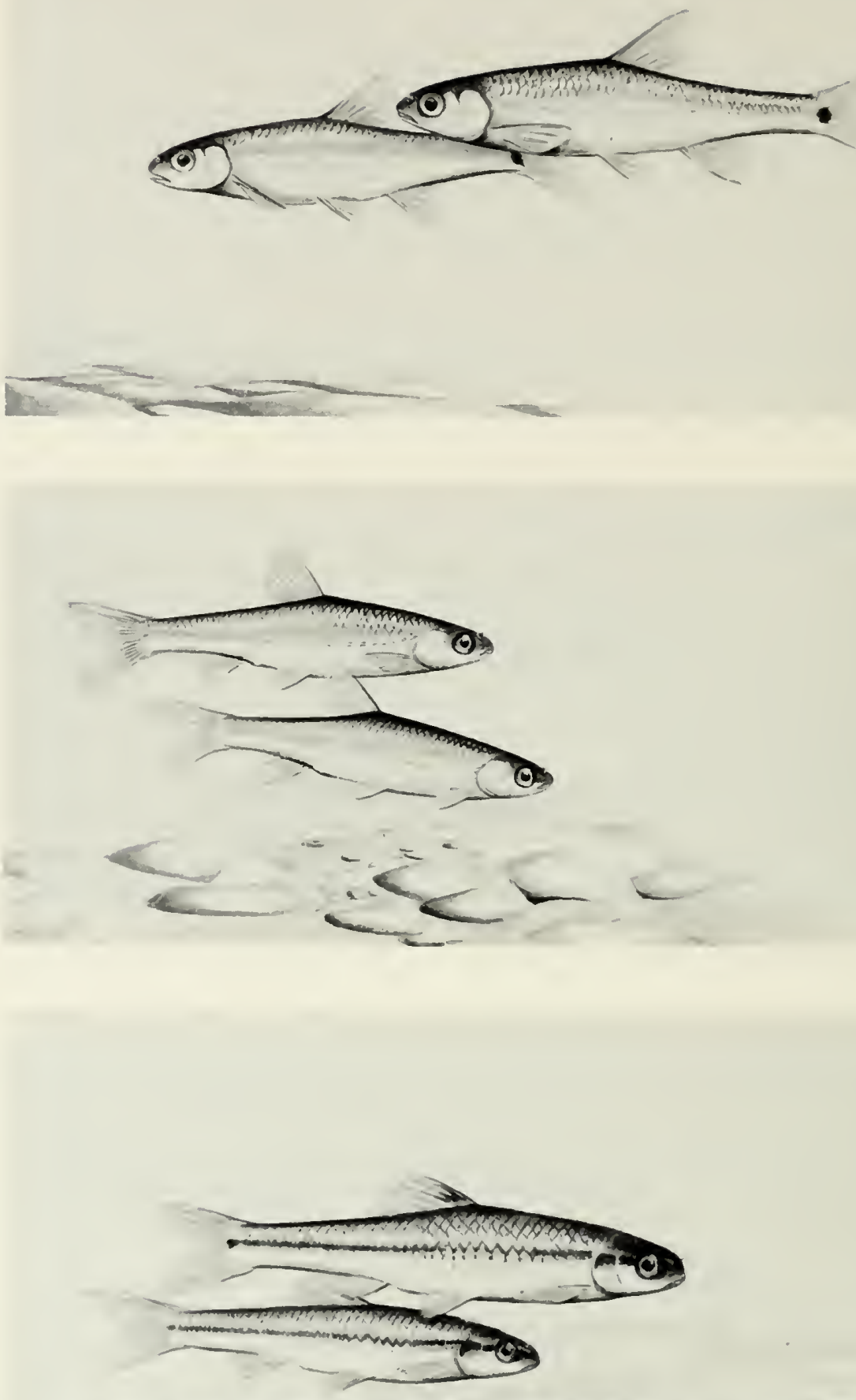


\section{Spottail Shiner-Notropis hudsonius}

Usualls 212 to 3 inches in length. this minnow has a stout, laterally compressed body and a bluntly pointed head with rather large eves. There is an obvious dark lateral band, which. in the young. ends at the tail. in the spot that gives the species its name. In larger individuals the spot is inconspicuous until death or preservation. The species is silvery to golden. with a greenish dorsal surface and a white belly.

The spottail shiner usually inhabits larger lakes and rivers and is more active at night than by day. In western Ontario the species may congregate in large numbers in the lower reaches of rivers in early June. Spawning takes place in late spring and early summer over sandy shoals. The spottail shiner can grow to 5 inches and probably lives a maximum of 4 or 5 years.

In Quetico this species has been found in 17 lakes and two rivers (see p. 56), all in the north and west, above a line from French Lake to Quetico Lake to Crooked Lake $(9.7 \%$, ranks 19 th $)$.

The spottail shiner is one of the most important forage fishes for sport fishes and is a good bait fish.

\section{Mimic Shiner-Notropis volucellus.}

The mimic shiner is usually $2-3$ inches in length and has a long. slender body. only moderately compressed, a small. terminal mouth. and rather large scales precisely outlined on the back. The dark lateral band is more obvious towards the tail. The lateral line resembles a series of "equals" signs. There is an obvious black speckling about the base of the anal fin. The general colouration is silvery.

Mimic shiners inhabit quiet water and are seen darting about in schools on sandy beaches in places such as Dawson Trail campsite.

This species is one of the commoner minnows in Quetico, and it is widely distributed throughout the park (see p. 56). It was taken at 37 localities, mainly lakes (19.0\%, ranks 11 th with the blacknose shiner).

\section{Bluntmose Minnow-Pimephales notanus}

This is an elongate, cylindrical minnow, not deep-bodied. The head is small, broad, flat on top, and bluntly rounded at the snout. The mouth is small and overhung by the snout. The scales are small, and on the back behind the head appear smaller than elsewhere. The scales have dark edges which mark the body with crossed lines. The back is dark, the sides silver, and the belly white. A prominent, black lateral band extends from snout to tail, where it ends in a conspicuous spot. Large tubercles appear on the snouts of breeding males.

Bluntnose grow to 4 inches in length and 4 years of age. They live in the shallow water of lakes and ponds over sand or gravel and in gravelly streams, but they appear to avoid weeds.

This is apparently the commonest minnow in the park, and in fact ranks behind only five other Quetico fishes in frequency of occurrence. It occurs throughout the park (see p. 56) and was taken at 58 localities $(29.7 \%$, ranks 7 th). 
44 QUETICO FISHES
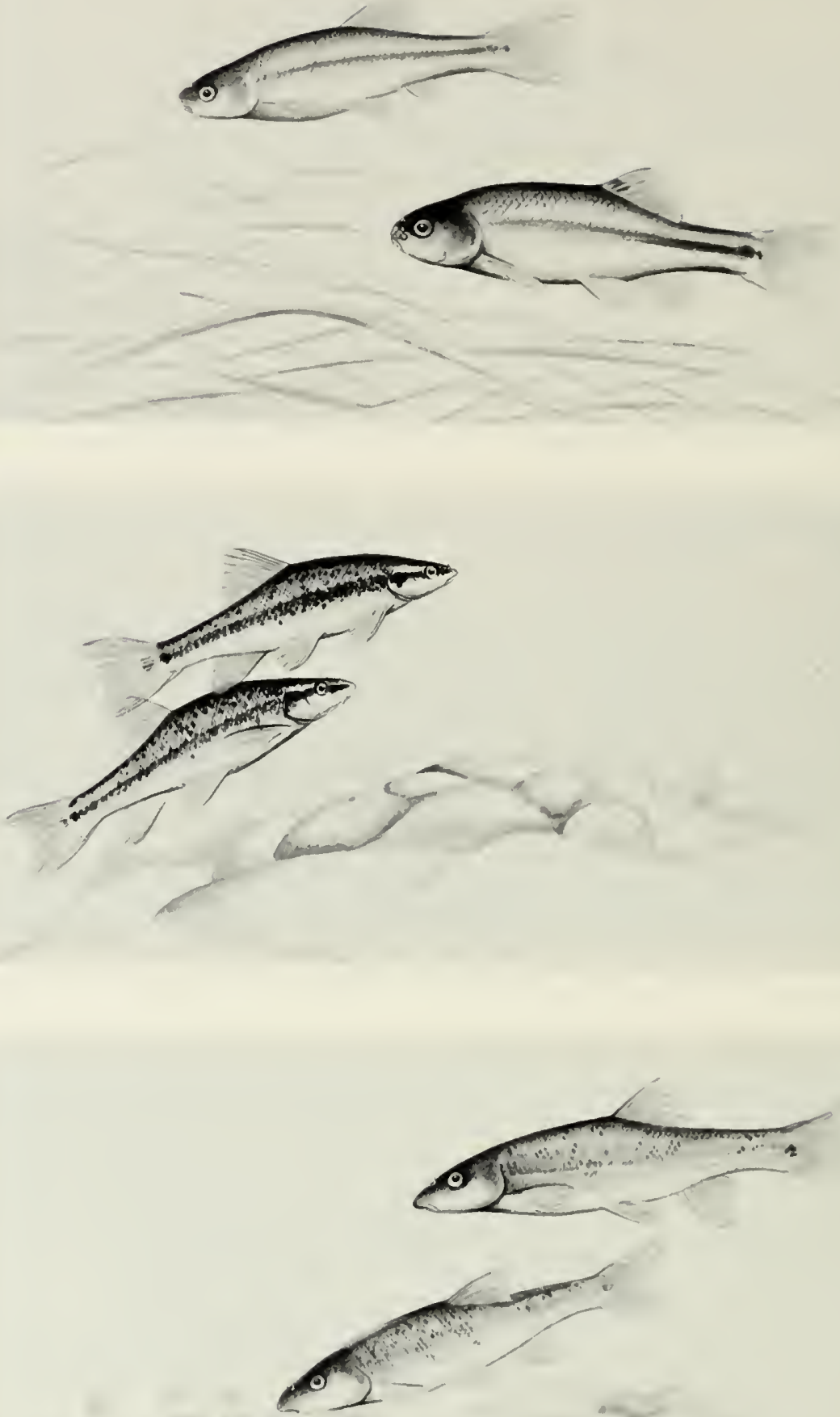


\section{Fathead Minnow-Pimephales promelas}

This minnow is usually about 2 inches long, deep-bodied, somewhat pot-bellied, and laterally compressed. The back. just behind the head. is slightly humped. The head is broad. with a small mouth. and the snout overhangs the upper lip slightly. Scales are large enough to be seen. This is a dark-coloured species, olive-green or brown on the back and upper sides and silvery white below, with a prominent dark lateral band. Breeding males are unmistakable, as they are velrety and grey-black. and have a spongy ridge on the back and well-developed tubercles on snout and lower jaw.

In Quetico fathead minnows inhabit the quiet water of ponds. the clear. dark. bogg! water of beaver ponds, and similar small lakes.

This species is not well known in Quetico (see p. 57). It was taken in only four lakes. one in the northwest and three in the southeast $(2.1 \%$, ranks 28 th with the lake sturgeon).

\section{Blacknose Dace-Rhinichthys atratulus}

This is another of the finescale minnow's. The body is stout and rounded, and the head broad. The upper lip slightly overhangs the inferior mouth, whereas in the longnose dace the overhang is much greater. There is a small barbel at each corner of the mouth. The blacknose dace is dark on the back and upper sides. with scattered speckles along the sides; the belly is silver-white.

The arerage length is $2 \frac{1}{2}$ inches, and life expectancy no more than 4 years.

The blacknose dace usually lives on the bottom in clear, swift. gravelly streams. However. in Quetico this dace is at present known only from seven lakes (see p. 57), mainly in the southern border area (3.6\%. ranks 25 th with three other species).

\section{Longnose Dace-Rhinichthis cataractae}

Like the preceding species, to which it is closely related, the longnose dace is a stout-hodied, finescaled minnow. It averages 3 inches in length, is nearly round in cross-section, and has a rather deep body, with a humped back. It has a broad head, a long. turned-down and pointed snout, and small eyes. The mouth is inferior and is noticeably overhung by the bulbous snout. There is an inconspicuous barbel at each corner of the mouth. The back and upper sides are olive to gres. the lower parts creamy to white. There is a dark lateral band.

This bottom-dwelling minnow. characteristic of clear, swift, gravelly to bouldery streams, also occurs along shores of lakes over the same type of bottom. In Quetico it was found in 26 locations (see p. 57) over the whole of the park (13.3\%, ranks 14th with the lake whitefish). 

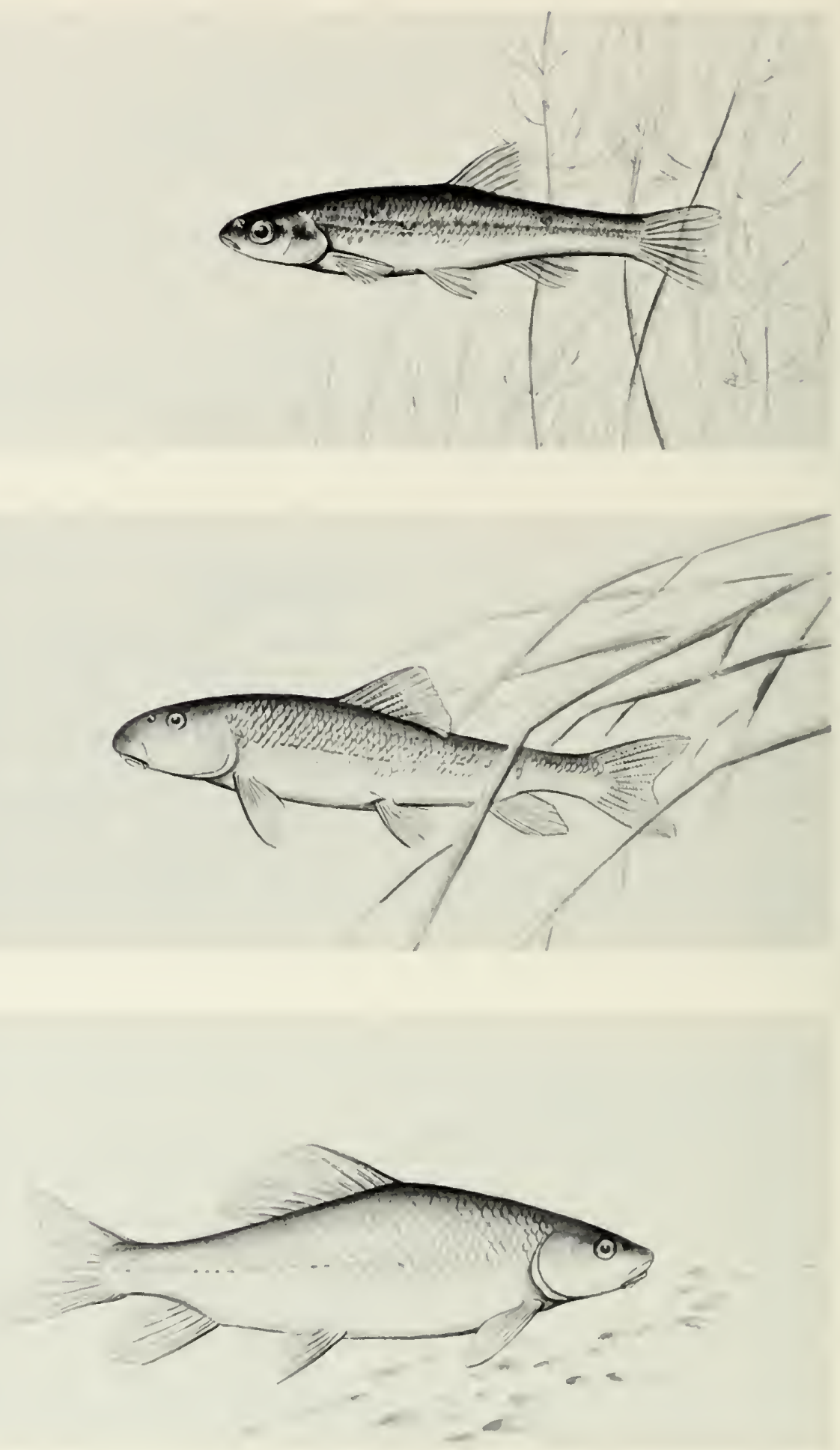


\section{Pearl Dace-Semotilus margarita}

This is one of the larger minnows, averaging $3 \frac{1}{2}$ inches in length. It is a robust, cylindrical fish with small scales, a rather small head, and a moderate-sized mouth. Usually there is a barbel on each side of the mouth. but one or both of these may be missing.

This species is generally black above and silvery on the sides with scattered speckled scales. There is a dark lateral band ending in a small spot at the tail.

This species is most often found in dark, peaty water of streams, beaver ponds. small lakes, and bays of larger lakes. Pearl dace have been collected from only six locations (see p. 57) in the park (3.1\%, ranks 26th).

The creek chub, Semotilus atromaculatus, very common elsewhere in the province. is not known with certainty to occur in the park. It was reported in 1971 and 1972 from the lake between Argo and Darky lakes in the southwest of the park. These records cannot now be authenticated. Therefore this large minnow, with a prominent black spot at the anterior base of the dorsal fin, should be watched for.

\section{White Sucker-Catostomus commersoni}

This very common species is most easily recognized by the undershot, suctorial mouth, with large. rough lips. The body is cylindrical, the head long and broad, the eyes small and high on the head, the scales large and obvious. The anal fin is long and pointed, and often has prominent tubercles. White suckers, oddly enough. are usually grey to brown above and milk-white below. When they are 2-6 inches long, they have three prominent black spots on the sides of the body.

In Quetico, individuals of this species are usually 6-22 inches long, but elsewhere they grow to at least 25 inches in length and 7 pounds in weight.

White suckers inhabit the top 20-30 feet of warm, shallow lakes, shallow bays of larger lakes, and tributary rivers and creeks. This is the third most abundant species in the park. It occurs over the whole area (see p. 57) and has been taken in 80 localities ( $41.8 \%$, ranks 3 rd).

This species provides food for a number of fishes man considers important. It is perfectly edible and is delicious when smoked.

\section{Silver Redhorse-Moxostoma anisurum}

This species is recorded only on the basis of a 1963 listing from Lac la Croix. However, a misidentification could have been involved, because the shorthead redhorse was also listed for Lac la Croix and is known also from Basswood Lake.

Redhorses are large suckers. deeper-bodied and more laterally compressed than white suckers. Like the white sucker, they will be easily recognized by their ventral, suctorial mouth with large, rough lips, and by their large dorsal fins. It is much more difficult. however, to distinguish the various redhorses from one another. especially in the field. 
<smiles>CCC1CC1</smiles>

$$
\text { tent }
$$




\section{Shorthead Redhorse-Moxostoma macrolepidotum}

This deep-bodied. laterally compressed sucker is distinguished from the silver redhorse by the fact that the edge of the wider, posterior or lower lip. rather than forming a $90^{\circ}$ angle, is gently bowed. and the upper lip is at least partially grooted. These features. together with the deep. compressed body with arched back. distinguish this species also from the white sucker.

Shorthead redhorses are found in the shallow, clear waters of lakes or clear, weedless rivers with bottoms of sand or gravel. Skin-divers may see wary groups of these large fishes. especially during the spring spawning migrations. At spawning time, redhorses move in to large streams with gravelly riffles.

This species is known to occur at 12 locations (see p. 57) in the eastern part of the park from French Lake to Basswood Lake and Lac la Croix $(6.2 \%$, ranks 23 rd with the green sunfish). Like the white sucker, it is edible but is rarely caught by anglers.

\section{Tadpole Madtom-Noturus grinus}

This is the only catfish at present known from the park. The prominent whiskers. the tiny eyes, the scaleless condition of the skin, the sharp spines in the dorsal and pectoral fins, the long. low adipose fin on the back. and the large. very round caudal fin distinguish this species from all others in the park. Tadpole madtoms are usually 2 inches, and rarely more than 3 inches, in length.

This tiny catfish occurs in slow-moving water, shallow lakes, ponds, and weedy stream mouths with muddy bottoms.

It has been taken in 24 localities (see p. 57) in the western half of the park (12.3\% ranks 15 th $)$.

The tadpole madtom is unique among Quetico fishes in having a poison gland associated with each sharp pectoral spine. Madtoms can inflict very painful, but not dangerous. wounds.

\section{Burbot-Lota lota}

This distinctive freshwater codfish is easily recognized. Noother fish in Quetico has a short-based spineless dorsal fin followed by a very long-based spineless dorsal fin, a round tail fin. and a long-based anal fin. The single barbel under the tip of the lower jaw, the long, pot-bellied, seemingly scaleless body, and the marbled colour pattern further characterize this species, which grows to 23 inches.

Burbot are usually found at moderate depths in lakes and. less frequently, in large, deep, cool rivers.

This species occurs at scattered localities everywhere in the park except in the central and southern portions of the eastern half (see p. 58). The burbot was taken in 21 localities (10.8\%, ranks 17 th).

This fish is neglected almost everywhere, and yet its flesh is excellent to eat and makes very good fish chowder. 

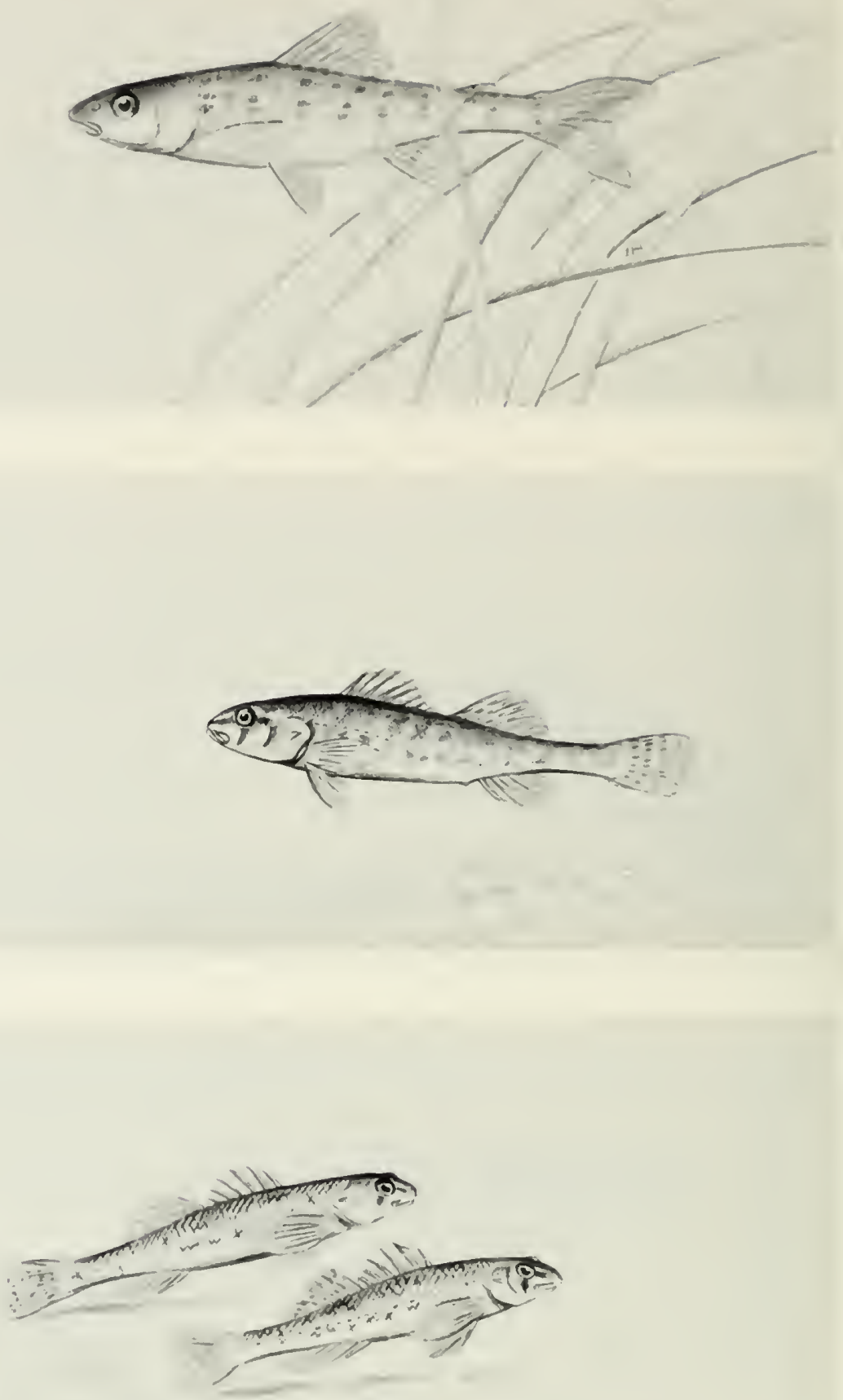


\section{Troul-Perch-Percopsis omiscomalcus}

The trout-perch. like the trouts, has a small adipose fin, but the scales feel rough (because of teeth-like etenii on them), as do those of perches. Trout-perch are usually $3-4$ inches long. with the body rounded and heaviest behind the large head. The snout is long and pinched, the eyes are large, and the mouth is small and overhung by the snout. The overall colour is silvery to golden. and there are five rows of obvious, large, black to brown spots from the back to the middle of the sides. The row of about 10 spots along the lateral midline is the most conspicuous.

Usually found at moderate depths in lakes in the daytime, trout-perch move into shallow water after dark. Their maximum size is about 6 inches.

In Quetico the species is known from only five localities (see p. 58) across the northern part of the park (2.6\% ranks 27 th with the silver lamprey).

\section{Iowa Darter-Etheostoma exile}

This small, colourful member of the perch family rarely reaches 3 inches in length or lives longer than 3 years. The body is somewhat cylindrical, and the snout small and pointed. with a small mouth. This darter has the spiny and soft dorsal fins typical of the perches. and a banded. rounded caudal fin. The lowa darter is distinguished from the two other darters in Quetico by the bright colours and the 10-14 dark vertical hars.

The breeding male is one of our most decorative fishes. The spiny dorsal fin has bands of blue. transparent orange, and blue-green. The body is blue, orange, and yellow. The lower fins are yellow to orange.

This darter dwells on the bottom. where it darts about with swift. jerky motions. It is found in clear, shallow, cooler water over sandy to soft bottom. The lowa darter occurs throughout the park (see p. 59) and was taken in 55 localities $(28.2 \%$. ranks 8 th $)$.

\section{Johnn! Darter-Etheostoma nigrum}

This is the second most abundant of the three darters at present known from Quetico. It is distinguished from the lowa darter by the absence of the bright blue and orange markings and by the obvious small black lateral markings. which resemble the letters $M . V$. and $W$. Breeding males become very black. and these lateral markings are then obscured.

This species is found in quiet water and almost always on sandy or gravelly bottoms. It rarely reaches 3 inches in length and lives only 3 or 4 years. The Johnny darter was taken in 46 localities (see p. 59) over most of the park (23.6\%. ranks 9 (h). 
52 QUETICO FISHES
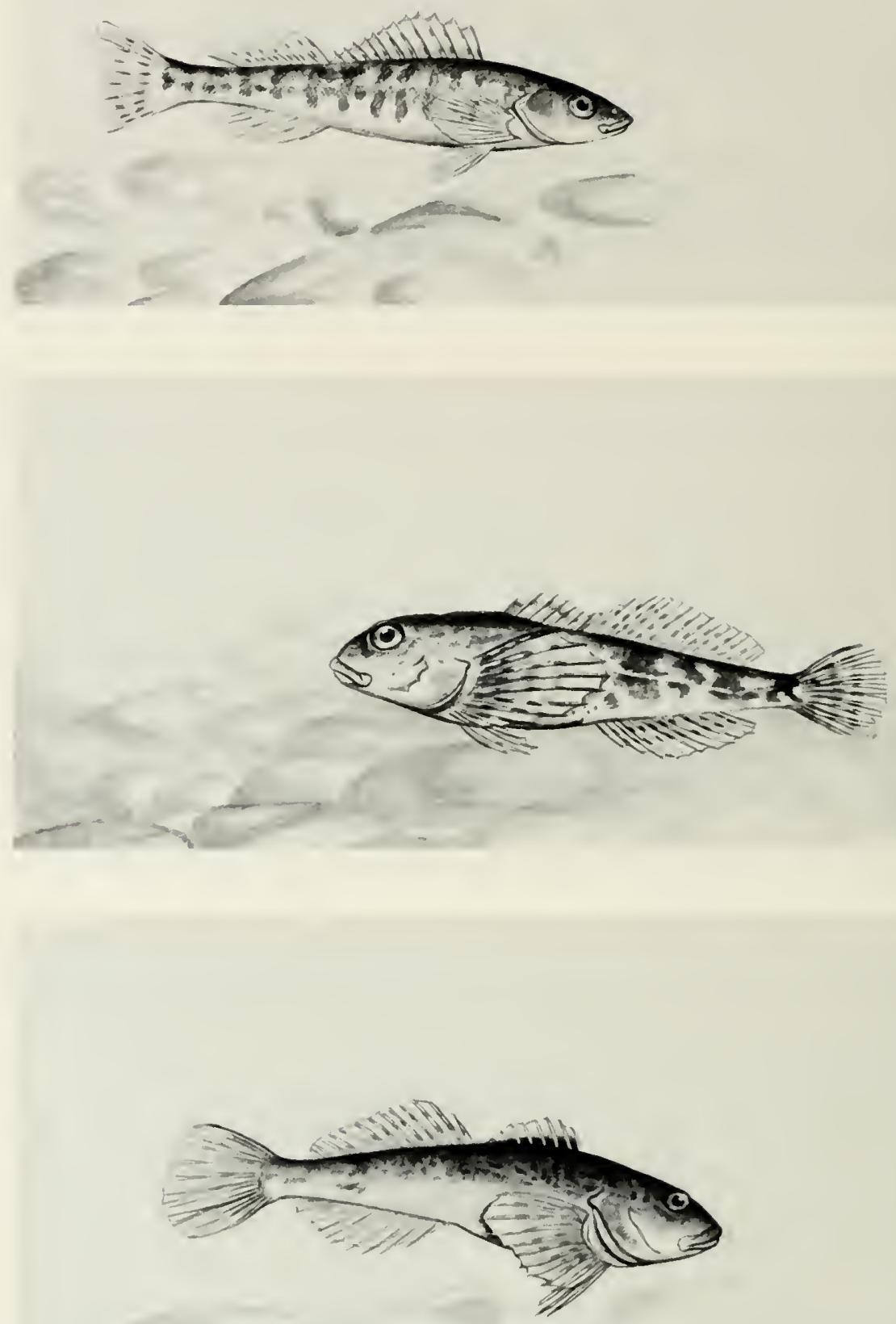


\section{Logperch-Percina caprodes}

This is the largest of the three darters in the park. but not the most abundant. The logperch grows to 3 or 4 inches, and has a cylindrical body with a rather long. pointed snout and prominent lips. There are wo dorsal fins, of which the first his fine spines. The colouration is green to grey-green on the back and yellow on the sides, and there are prominent tapering vertical bars on the sides. some of which end in teardrop expansions.

Until late June logperch remain in deeper, offshore water. Then, at spawning time, large schools may be seen on sandy shoals. Later. smaller groups and individuals will be seen offshore. in sandy, gravelly, or rocky surroundings.

The logperch is widely distributed in the park (see p. 59) and was taken from 24 scattered localities $(12.3 \%$, ranks $15 \mathrm{th})$.

This species is sometimes used as bait for other fishes. but logperch are difficult to keep alive.

\section{Mottled Sculpin-Cotms bairdi}

The mottled sculpin has a large, flattened head, with large, bulging eyes high up. The body is broad and cylindrical in front but tapers and is more compressed posteriorly: There are two dorsal fins, the first with weak spines, the second higher and longer. The anal fin is long, and the pectoral fins are extremely large, round. and fan-like. The pelvic fins usually have four discernible rays. The first dorsal fin has a spot at the front and another at the rear, and the rounded cau$\mathrm{dal}$ fin is banded. They rarely exceed 3 inches in length.

This sculpin occurs on the bottoms of cool streams and lakes, usually on sand. Sculpins have no swim bladder for buoyancy. They dart about or remain still. perched on the pelvic fins, on the bottom. where because of their colouration they are almost invisible. This fish is known to occur in 22 locations in the park (see p. 60) but appears to be absent from the southeast portion $(11.3 \%$, ranks 16th). They will not often be seen by the casual park visitor.

The mottled sculpin sometimes constitutes an important food item for trout.

\section{Slimy Sculpin-Cottus cognatus}

In general, this species has the same characteristics as the mottled sculpin. However. the slimy sculpin has a wide band of black pigment at the base of the spiny or first dorsal fin; its rounded caudal fin or tail is less markedly pigmented than that of the mottled sculpin; and its pelvic fins usually have only three discernible rays.

This species occurs in deeper, cool water on gravelly or rocky bottom and. like the mottled sculpin, will only rarely be seen by the park visitor or angler. It is a food item for lake trout and brook trout.

The slimy sculpin is at present known to occur in only seven widespread localities in the park (see p. 60). It appears to be absent from the southern border lakes and their tributaries $(3.6 \%$, ranks 25 th with three other species). 


\section{DISTRIBUTION}

\section{List of Species and the Bodies of Water from Which They Are Known}

Species are listed here in the order of the checklist, not in the order of the species accounts. Names in brackets identify a particular bay of the lake. Figures to the right of the species name indicate the number of localities at which that species was taken, the percentage that number is of the total number of localities, and the rank for that species in frequency of occurrence of all species. See pp. viii-ix for details concerning these figures, QFP lakes, and unnamed lakes.

Ichthyomyzon unicuspis - silver lamprey

Crooked, Kawnipi, Lac la Croix, Lonely, Saganaga.

Acipenser fulvescens - lake sturgeon

Eva, Lac la Croix, Sturgeon, QFP Lake 30 Block 5.

Salvelinus fontinalis-brook trout

Hop Lake.

Salvelinus namaycush-lake trout

$77 / 39.5 / 4$

Agnes, Antoine, Argo, Badwater, Basswood, Batchewaung, Beaverhouse, Brent, Buckingham, Burke, Burntside, Burt, Cache, Carp, Cirrus, Cone, Crooked. Cypress. Darky, Doré. Draper, Elk. Emerald. Eva, Ferguson. Franch. Glacier. Jean, Jeff, Joyce, Kawnipi, Kahshahpiwi, Keefer, Kett, Knife, Lac la Croix, Louisa, McAlpine, McAree, McDougall, McEwen, McIntyre, McNiece, Nest, Olifaunt. Oriana, Other Man, Pickerel, Plough, Poacher, Pond, Poohbah, Quetico, Ram, Ranger Bay (Basswood), Rawn, Robinson, Roland, Saganaga, Saganagons, Sarah, Sark, Shade, Sheridan, Side, Soho, Sturgeon, Summer, Sunday, Ted, That Man, This Man, Tilly, Tuck, Walter, Yum Yum. QFP Lake 8 Block 5 .

Coregonus artedii-cisco

$34 / 17.4 / 12$

Argo, Badwater, Ballard, Basswood, Bearpelt, Brent, Brylcreme, Burke, Carp, Cirrus, Crooked, Darky, Eva, French, Gardner Bay (Crooked). Kasakokwog, Lac la Croix, Louisa, McAree, McNaught. Middle Roland, Minn. Omeme, Pickerel, Pond, Pulling, Quetico, Robin. Robinson, Silence. Sturgeon. Sunday, QFP Lake 6 Block 2, lake between Dell and Isabella. 
Coregonus clupeaformis-lake whitetish

$26 \quad 13.3 \quad 14$

Agnes. Badwater. Basswood. Beaverhouse, Brewer, Brylereme. Carp. Cirrus. Crooked, Darky. Eva. French. Gardner Bay (Crooked), Lac la Croix, Liule Roland, McAree, Minn. Pickerel, Pond, Quetico, Robinson, Saganaga. Silence. Sturgeon. Sunday, QFP Lake 78 Block 8.

Coregonus zenithicus - shortjaw cisco

Basswood Lake.

Osmerus mordax-rainbow' smelt

Eva Lake. French Lake

Hiodon tergisus - mooneye

Wawiag River

Umbra limi-central mudminnow

Bart, Basswood.

Esox lucius - northern pike

Agnes, Alice, Antoine, Anubis, Argo, Badwater, Baptism, Bart, Basswood. Batchewaung, Bearpelt, Beaverhouse, Beg, Bentpine. Birch. Bird, Bisk, Brent. Brewer. Buckingham, Bud, Burke, Burntside, Burt, Cache, Cache Bay (Saganaga). Cairn, Carp, Ceph, Chatterton. Cirrus, Conk, Conmee, Crooked, Cub, Cypress, Dahlin, Darky, Delahey, Doe, Doré. Draper. Edge. Elizabeth. Eva. Ferguson, Fern, Fred, French, French River, Gardner Bay (Crooked). Heronshaw. Howard, Isabella, Jack, Jean, Jeff, Jessie, Joyce, Kahshahpiwi, Kasakokwog. Kawnipi, Keats, Keefer, Kenny, Kett, Knife, Lac la Croix. Lakin. Lily Pad, Little Falls, Little Roland, Lonely, Lynx, Mack, Maria, McAree, McDougall, McEwen, Mclntyre, McNaught, McNiece, Merriam Bay (Basswood), Middle Roland, Minn, Murdock, No Man, North Bay (Basswood), Olifaunt, Omeme. Oriana, Other Man, Pickerel, Pickerel River, Plough, Poacher, Point, Poohbah, Quetico, Ram, Ranger Bay (Basswood), Rawn, river to Rawn, Robin, Robinson, Roland, Rouge, Russell, Saganaga, Saganagons, Sarah, Sark, Shade. Shelly, Sheridan, Side, Silence, Silver Falls River, Slate, Soho, Sturgeon. Sucker, Sultry, Summer, Sunday, Tanner, That Man, Tilly, Trouser, Tuck, Vernon. Walter, West, West Bay (Quetico), Wet, Wicksteed. Wild Goose. Windigoostigwan. Wolseley, Yeh. Your, Yum Yum. QFP Lake 1 Block 1, Lake I Block 2, Lake 3 Block 2, Lake 6 Block 2, Lake 11 Block 2, Lake 7 Block 5, Lake 25 Block 5. Lake 30 Block 5, lake on Irving 1sland, lake between Bell and Bit.

Chrosomus eos - northern redbelly dace

$18 / 9.2 / 20$

Agnes, Ballard, Bart, Cache River, Crooked, Dahlin, Darky, Gratton. Mack. McAlpine, Omeme, Other Man, Quetico, Smally, Wicksteed, QFP Lake 8 Block 5. Lake 16 Block 5, Lake 30 Block 5.

Chrosomus neogaeus-finescale dace

Agnes, Badwater, Bart, Cirrus, Conk, Crooked, Dahlin, Dell. McAree, McKenzie Bay (Kawnipi), Quetico. Silence, Smally, Sturgeon, This Man, Wolseley. QFP Lake 16 Block 5. 
Couesius plumbeus-lake chub

Cache River.

Notemigonus crysoleucas-golden shiner

$14 / 7.2 / 22$ Burntside, Ceph, Cirrus, Conk, Darky, Kasakokwog, Lakin. Louisa, Lynx, Quetico, river to Rawn, Rouge, Your, QFP Lake 3 Block 2.

Notropis atherinoides - emerald shiner

Darky, French, Quetico.

Notropis cornutus-common shiner

$20 / 10.3 / 18$ Agnes, Beaverhouse, Brent, Burntside, Cache River, Cairn. Cirrus, Darky. French River, Lakin, McKenzie Bay (Kawnipi), Minn, Other Man. Pickerel River, Quetico, Rouge, Silence, That Man, QFP Lake 6 Block 2, Lake 30 Block 5 .

Notropis heterodon-blackchin shiner

Basswood, Bell, lake between Bell and Bit, Bentpine Creek, Quetico, Rouge. stream between Isabella and North Bay (Basswood).

Notropis heterolepis - blacknose shiner

$37 / 19.0 / 11$ Badwater, Bart, Basswood, Bearpelt, Beg, Bisk, river from Pickerel to Bisk, Brent, Burntside, Cirrus, Conk, Crooked, Dahlin, Darky, Gardner Bay (Crooked), Kasakokwog, McAlpine, McAree, Minn, Omeme, Other Man, lake between Other Man and Bit, Pond, Poohbah, Quetico, Rawn, river to Rawn. Robinson, Rouge, Silence, lake above Silence, That Man, Wicksteed. Your, QFP Lake 3 Block 2, Lake 5 Block 2, river between Brylcreme and Buckingham.

Notropis hudsonius - spottail shiner

$19 / 9.7 / 19$ Argo, Beaverhouse, Beg, Bisk, Brylcreme, river between Brylcreme and Buckingham, Burntside, Cirrus, Conk, Crooked, French, Jean, Pickerel River, river from Pickerel to Bisk, Quetico, Rawn, Sturgeon, Windigoostigwan, Wolseley.

Notropis volucellus - mimic shiner

$37 / 19.0 / 11$

Agnes, Bisk, Brent, Brylcreme, Buckingham, Carp. Cirrus. Conk, Crooked, Darky, French, French River, Gardner Bay (Crooked), Isabella, Jean, Kasakokwog, Little Roland, Mack, Middle Roland, Omeme, Pickerel. Pickerel River. river from Pickerel to Bisk. Pond, Quetico, Rawn. Robinson, Rouge, Russell. Sturgeon, Sunday, Windigoostigwan, Wolseley, Your, QFP Lake 3 Block 2 , Lake 78 Block 8, lake above Silence.

Pimephales notatus-bluntnose minnow

$58 / 29.7 / 7$ Agnes, Ballard, Bart, Basswood, Beaverhouse, Beg, Bell, lake between Bell and Bit, Bisk, Brent, Buckingham, river between Brylcreme and Buckingham, Burntside, Cairn, Ceph, Cirrus, Conk, Crooked, Darky, Emerald. French, Gardner Bay (Crooked), Jean, Lakin, Mack, McAree, Minn, No Man, Omeme. Pickerel, river from Pickerel to Bisk, Pond, Quetico, Robinson, Rouge, Russell, Shade. Silence, lake above Silence, Smally, Solıo, Sturgeon, Summer, Sinday. That Man, Walter, Wicksteed, Wolseley, Yeh, Your, Yım Yum, QFP Lake 1 
Block 2. Lake 3 Block 2. Lake 5 Block 2. Lake 7 Block 5. Lake 25 Block 5. Lake 30 Block 5. lake between Bit and Other Man.

Pimephales promelas - fathead minnow

No Man. Smally. That Man. lake between Bit and Other Man.

Rhinichthy's atratulus-blacknose dace

Beaverhouse, No Man. Quetico. Robin. That Man. This Man. QFP Lake 25 Block 5 .

Rhinichthys cataractae-longnose dace

$26 / 13.3 / 14$

Ballard. Beg. pond between Beg and Bisk, Brylcreme, Cairn. Chatterton, Conk. Dell. Jean. Kasakokwog, Lonely. McAlpine. McAree, Minn, Oriana, Poohbah, Quetico, Robin, Robinson, Rouge, Shade, Silence, QFP Lake 6 Block 2, Lake 78 Block 8, stream between Isabella and North Bay (Basswood), river from Pickerel to Bisk.

Semotilus atromaculatus - creek chub

Lake 16 Block 5 (see p. 47).

Semotilus margarita-pearl dace

$6 / 3.1 / 26$

Buckingham, Cache River. That Man, creek from Little Eva at hwy. no. 11, McAlpine, river to Rawn.

Catostomus commersoni-white sucker

$80 / 41.8 / 3$

Agnes. Argo, Badwater. Ballard, Bart, Basswood. Beaverhouse. Beg, pond between Beg and Bisk. Bentpine Creek, Bisk, Brylcreme, river between Brylcreme and Buckingham, Buckingham, Burntside, Cache River, Carp, Cirrus, Conk, Crooked. Dahlin. Darky, Dell, lake between Dell and Isabella, Eva. French. French River, Gratton, Hop, Isabella, Jean, Kasakokwog. Lac la Croix, Little Roland, Louisa, Mack. McAlpine, McAree, McNaught, Middle Roland, Minn, North Bay (Basswood), Oriana, Other Man, Pickerel. Pickerel River, river from Pickerel to Bisk, Pulling, Quetico, Rawn, river to Rawn. Robin. Robinson. Roland. Rouge, Shade, Silence, lake above Silence, Sturgeon, Summer, Sunday, That Man, This Man, West, Wicksteed, Windigoostigwan, Wolseley. Yeh. QFP Lake 1 Block 1. Lake 1 Block 2, Lake 3 Block 2. Lake 5 Block 2, Lake 6 Block 2. Lake 7 Block 5, Lake 8 Block 5. Lake 16 Block 5. Lake 25 Block 5. Lake 30 Block 5. Lake 78 Block 8, river to Lindsay.

Moxostoma anisurum-silver redhorse

Lac la Croix.

Moxostoma macrolepidotum-shorthead redhorse

Ballard. Basswood, Brewer, Brylcreme. French, Lac la Croix, Little Roland, McAree. Minn, Quetico, Sturgeon, QFP Lake 30 Block 5.

Noturus gyrinus - tadpole madtom $2412.3 / 15$ Badwater, Bart, Basswood, Beaverhouse, Bentpine Creek, Brewer, Ceph. Conk. Crooked. Darky, Gardner Bay (Crooked). Gratton, Jean. McAree. Poohbah. Pulling, Quetico, Robinson, Rouge, Wicksteed, Yeh, QFP Lake 6 Block 2, Lake 25 Block 5, Lake 78 Block 8. 
Lota lota-burbot

$2 \mathrm{I} / 10.8 / 17$

Bart, Basswood, Beaverhouse, Beg. Brewer, Chatterton, Conk. Crooked, French, Jack, Lac la Croix, McAree, Omeme, Oriana, Pickerel, Rouge, Sturgeon, Wolseley, QFP Lake 1 Block 2, Lake 3 Block 2, tributary to Cache River.

Percopsis omiscomaycus - trout-perch

$5 / 2.6 / 27$

Beaverhouse, Bisk, river from Pickerel to Bisk, Cirrus, Quetico.

Ambloplites rupestris - rock bass

$40 / 20.5 / 10$

Agnes, Bart, Basswood, Beaverhouse, Bentpine. Bentpine Creek. Brewer, Burke, Cairn, Chatterton, Crooked, Dahlin, Darky, Gardner Bay (Crooked), Jean, Lac la Croix, Little Roland, McAree, Minn, North Bay (Basswood), Oriana, Poohbah. Pulling, Quetico, Robinson, Rouge, Shade, Silence. Slate, Sturgeon, Sunday. Walter, Wicksteed. Your, QFP Lake 3 Block 2. Lake 7 Block 5. Lake II Block 2. Lake 30 Block 5, Lake 78 Block 8, lake between Dell and Isabella.

Lepomis cyanellus - green sunfish

Ballard, Bell, Cirrus, Darky, Meadows, Other Man. Lake between Bit and Other Man, Smally, Sunday, That Man. This Man. QFP Lake 7 Block 5.

Lepomis gibbosus - pumpkinseed

$14 / 7.2 / 22$

Ceph, Darky, Lost Bay (Basswood), Lynx, McAree, Robin. Wicksteed, Yeh. Your, QFP Lake 5 Block 2, Lake II Block 2, Lake 30 Block 5, river between Brylcreme and Buckingham, stream between Isabella and North Bay (Basswood).

Lepomis macrochirus - bluegill

$7 / 3.6 / 25$

Bart. Crooked, Jean, Lost Bay (Basswood), McNaught, North Bay (Basswood), QFP l.ake 78 Block 8.

Lepomis megalotis - longear sunfish

$9 / 4.6 / 24$

Bart, Darky, Little Roland, Quetico, Rouge, Sunday, Yeh, QFP Lake 3 Block 2. stream between Isabella and North Bay (Basswood).

Micropterus dolomieui-smallmouth bass

$6 \mathrm{I} / 3 \mathrm{I} .3 / 6$

Agnes, Ballard, Bart, Basswood, Beaverhouse, Brewer, Burke, Burntside, Carp, Ceph, Crooked, Cypress, Dahlin. Darky, East, Eva, Fern. French, Gardner Bay (Crooked), Glacier, Grey, Isabella, stream between Isabella and North Bay (Basswood), Jean. Jeff, Kahshahpiwi, Knife, Lac la Croix. Lily Pad, Little Roland, Lonely, Maligne River, McAree, McEwen, Meadows, Middle Roland, Minn, Noon, Olifaunt, Pickerel, river from Pickerel to Bisk, Point, Pulling, Quetico, Ranger Bay (Basswood), Robinson, Rouge, Saganaga, Sarah, Shade, Silence, Slate, Sturgeon, Sunday, That Man, Walter, Wolseley. Yum Yum. QFP Lake 30 Block 5, Lake 78 Block 8, lake on Irving Island.

Micropterus salmoides - largemouth bass

$32 / 16.4 / 13$ Bart, Basswood, Brent, Burke, Burt, Crooked, Dell, lake between Dell and Isabella, Gardner Bay (Crooked), Gratton, Grey. Isabella, stream between Isabella 
and North Bay (Basswood), Jean. Mack. McNaught, Meadows, Noon, North Bay (Basswood). Oriana. Pulling, Quetico, Robinson. Sarah. Shade. Silence, Small, Sunday, Trant, West, Yeh, QFl' Lake 1 Block 2.

Pomoxis nigromaculatus-black crappie

$9 / 4.6 / 24$

Basswood. Bell. Cirrus. Darky. Lac la Croix. Meadows, Sunday. That Man. This Man.

Etheostoma exile-lowa darter

$55 / 28.2 / 8$

Agnes. Argo. Badwater, Ballard. Bart. Basswood. Beaverhouse, Brylcreme, Burntside, Cairn, Conk, Crooked, Dahlin. Darky, Dell, lake hetween Dell and Isabella. Emerald, Gardner Bay (Crooked), Gratton, Jean, Lakin. Little Roland, Lonely. Louisa, Lynx. McAlpine. McAree. Meadows, Middle Roland, Minn. Omeme, Oriana, Other Man, lake between Bit and Other Man, Poohbah, Pulling. Quetico, Robin. Robinson, Roland, Silence, lake above Silence, Soho, Sturgeon. Summer, That Man. Walter. Wicksteed, Wolseley, Yeh, QFP Lake 1 Block 2. Lake 5 Block 2. Lake 8 Block 5, Lake 16 Block 5, stream between Isabella and North Bay (Basswood).

Etheostoma nigrum-Johnny darter

$46 / 23.6 / 9$

Agnes, Basswood, Beaverhouse, Beg, Bisk, Buckingham, Burntside, Cairn, Chatterton. Conk. Crooked. Dell, lake between Dell and Isabella. French. French River, Jack, Jean. Kasakokwog. Lakin. McAree, McKenzie Bay (Kawnipi). Minn. Omeme. Oriana, Pickerel, Pickerel River, Pond, Poohbah, Quetico, Robinson. Rouge, Russell, Shade. Shelley. Silence, lake above Silence. Sturgeon, Summer. Walter. Wicksteed. Wolseley. QFP Lake 5 Block 2, Lake 6 Block 2. Lake 7 Block 5, Lake 30 Block 5, stream between Isabella and North Bay (Basswood).

Perca flavescens-yellow perch

$68 / 34.9 / 5$

Agnes. Argo, Badwater, Bart. Basswood, Bearpelt, Beaverhouse, Bentpine, Bentpine Creek. Bisk. Brylcreme, Buckingham, Burntside, Cache River, Carp, Cirrus, Conk, Crooked, Darky, Dell, lake between Dell and Isabella, Emerald, French. Gardner Bay (Crooked), Gratton, Isabella, Jack, Jean, Kasakokwog, Lac la Croix, Lakin. Little Roland, Louisa, Lynx, Mack, McAree, McKenzie Bay (Kawnipi). Middle Roland, Minn. Omeme, Oriana, Pickerel, river from Pickerel to Bisk. Pickerel River, Poobah, Quetico, Rawn, Robin, Robinson, Roland, Rouge. Shade. Silence, lake above Silence, Sturgeon, Summer, Wicksteed, Windigoostigwan, Wolseley, Yeh, Your, QFP Lake 1 Block 1, Lake 3 Block 2 , Lake 5 Block 2. Lake 6 Block 2, Lake 11 Block 2. Lake 16 Block 5, Lake 25 Block 5 .

Percina caprodes-log perch

$24 / 12.3 / 15$

Agnes. Beaverhouse, Bisk, Brylcreme, Burntside, Cirrus, Conk. Crooked, French. French River, Gardner Bay (Crooked), McAree, McKenzie Bay (Kawnipi), No Man, Pickerel River, river from Pickerel to Bisk, Pond, Quetico. Rouge, Walter, Wicksteed. Wolseley, QFP Lake 6 Block 2, Lake 25 Block 5. 
Stizostedion canadense - sa uger

Lac la Croix, Pickerel Lake.

Stizostedion vitreum-walleye

$123 / 63.2 / 2$

Agnes, Anubis, Badwater, Ballard, Bart, Basswood, Batchewaung. Bearpelt. Beaverhouse, Beg, pond between Beg and Bisk, Bentpine, Bird. Bisk. Bit, Brent. Brewer, Brylcreme, Buckingham, Bud, Burke, Burntside, Burt, Cairn. Carp, Ceph. Chatterton, Cirrus, Conk, Conmee, Crooked, Cub, Cypress, Darky, Delahey, Draper, East, Elizabeth, Fern. Fred, French, Gardner Bay (Crooked), Glacier, Heronshaw, Isabella, Jack, Jean, Jessie, Joyce, Kahshahpiwi, Kasakokwog. Kawnipi, Keats, Keefer, Kenny, Knife, Lac la Croix. Lily Pad, Lonely. Mack. Maria, McAlpine, McAree. McEwen, McIntyre, McKenzie Bay (Kawnipi), Merriam Bay (Basswood), Minn, Murdock, No Man, North Bay (Basswood). Olifaunt, Omeme. Oriana, Other Man, Pickerel, river from Pickerel to Bisk. Pickerel River, Poohbah. Quetico. Ranger Bay (Basswood). Rawn. Robin. Robinson, Roland, Rouge, Russell, Saganaga, Saganagons, Sarah, Sark, Shade, Shelley, Silence, Silver Falls River, Slate, Soho, Sturgeon, Sucker, Sultry, Summer, Sunday, Tanner, Ted. That Man, This Man, Tuck, Vernon, Walter, Wawiag River, West, West Bay (Quetico), Wet. Wild Goose. Wolseley, Yeh. Your, Y um Yum, QFP Lake I Block 1, Lake 3 Block 2, Lake 7 Block 5, Lake 30 Block 5, Lake 78 Block 8.

Cottus bairdi-mottled sculpin

$22 / 11.3 / 16$

Bart. Beaverhouse, Burntside, Cairn, Chatterton, Cirrus, Conk, Crooked, Dell, Kasakokwog, McAree, Middle Roland, Omeme, Pond, Pulling, Quetico, Rouge, Shelley, Walter, Wolseley, QFP Lake 3 Block 2, Lake 30 Block 5.

Cottus cognatus-slimy sculpin

Agro, Brent, Cirrus, Emerald, Louisa, Shade, river from Pickerel to Bisk. 


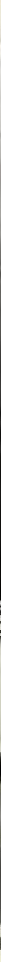

Above: A survey crew prepares to fly into remote Quetico lakes.

Right: Equipment for determining the physical and chemical composition of the lakes.

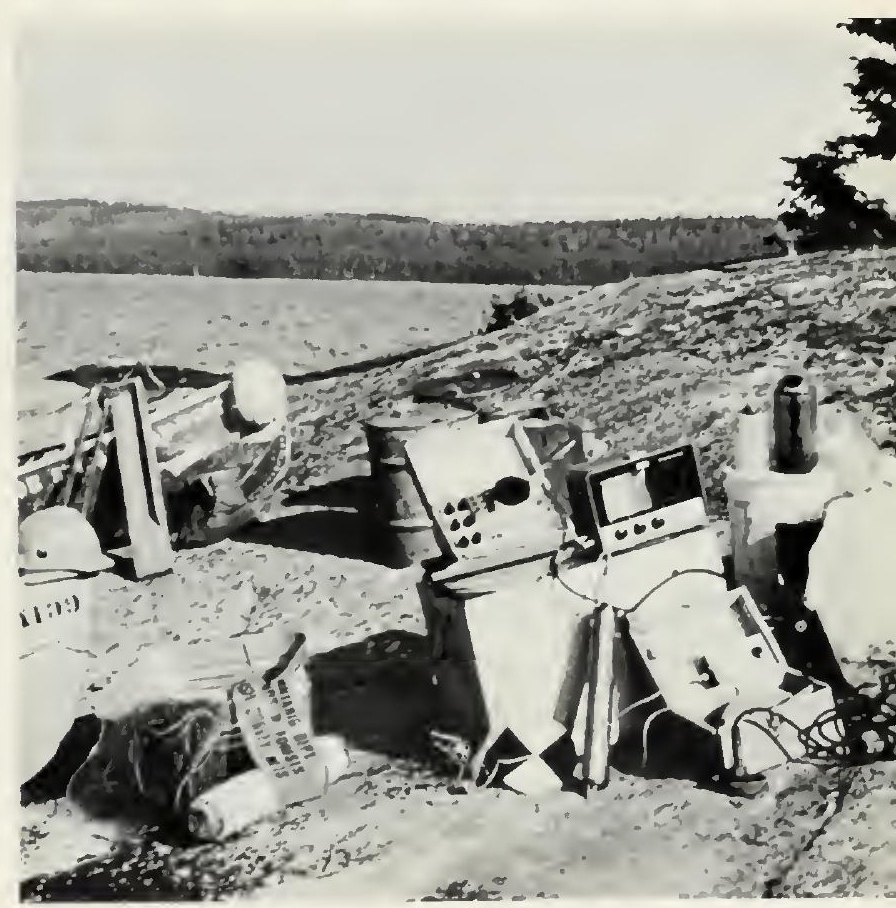


Left: Collecting fishes in the Quetico lakes 


\section{DISTRIBUTION}

\section{Alphabetical List of Bodies of Water with the Species Known to Occur in Each}

Species are listed in the order in which they appear in the checklist, not in order of abundance in the lake. See p. viii for an explanation of the variation in number of species listed for different lakes. The latitude and longitude given for lakes are approximately those of the lake centre, those given for streams indicate the location of the actual collection site.

Agnes Lake, $48^{\circ} 10^{\prime} \mathrm{N}, 91^{\circ} 21^{\prime} \mathrm{W}$-lake trout, lake whitefish, northern pike, northern redbelly dace, finescale dace, common shiner, mimic shiner, bluntnose minnow. white sucker, rock bass, smallmouth bass, lowa darter, Johnny darter, yellow perch, log perch, walleye.

Alice Lake, $48^{\circ} 30^{\prime} \mathrm{N}, 91^{\circ} 22^{\prime} \mathrm{W}$-northern pike.

Antoine Lake, $48^{\circ} 31^{\prime} \mathrm{N}, 91^{\circ} 32^{\prime} \mathrm{W}$-lake trout, northern pike.

Anubis Lake, $48^{\circ} 20^{\prime} \mathrm{N}, 91^{\circ} 15^{\prime} \mathrm{W}$-northern pike, walleye.

Argo Lake, $48^{\circ} 15^{\prime} \mathrm{N}, 91^{\circ} 48^{\prime} \mathrm{W}$-lake trout, cisco, northern pike, spottail shiner, white sucker, lowa darter, yellı 'p rch, slimy sculpin.

Badwater Lake, $48^{\circ} 29^{\prime} \mathrm{N}, 91^{\circ} 56^{\prime} \mathrm{W}$ - lake trout, cisco, lake whitefish, northern pike, finescale dace, blacknose shiner, white sucker, tadpole madtom, Iowa darter. yellow perch, walleye.

Ballard Lake, $48^{\circ} 18^{\prime} \mathrm{N}, 91^{\circ} 49^{\prime} \mathrm{W}$ - cisco, northern redbelly dace, bluntnose minnow, longnose dace, white sucker, shorthead redhorse, green sunfish, smallmouth bass, lowa darter, walleye.

Baptism Lake, $48^{\circ} 37^{\prime} \mathrm{N}, 91^{\circ} 08^{\prime} \mathrm{W}$-northern pike.

Bart Lake, $48^{\circ} 11^{\prime} \mathrm{N} .91^{\circ} 42^{\prime} \mathrm{W}$-central mudminnow, northern pike, northern redbelly dace, finescale dare, blacknose shiner, bluntnose minnow, white sucker, tadpole madtom, burbot, rock hass, bluegill, longear sunfish, smallmouth hass, largemouth bass. Iowa darter, yellow perch. walleye, nıottled sculpin. 
Basswood Lake, $48^{\circ} 06^{\prime} \mathrm{N}, 91^{\circ} 33^{\prime} \mathrm{W}$-lake trout, cisco, shortjaw cisco, lake whitefish, central mudminnow, northern pike, blackchin shiner, blacknose shiner, bluntnose minnow, white sucker, shorthead redhorse, tadpole madtom. burbot, rock bass, pumpkinseed, bluegill, longear sunfish. smallmouth bass, largemouth bass, black crappie, lowa darter, Johnny darter, yellow perch. walleye.

Batchewaung Lake, $48^{\circ} 40^{\prime} \mathrm{N}, 91^{\circ} 30^{\prime} \mathrm{W}$-lake trout, northern pike, walley'e.

Bearpelt Lake, $48^{\circ} 28^{\prime} \mathrm{N}, 92^{\circ} 04^{\prime} \mathrm{W}$ - cisco, northern pike, blacknose shiner, yellow perch, walleye.

Beaverhouse Lake, $48^{\circ} 33^{\prime} \mathrm{N}, 92^{\circ} 03^{\prime} \mathrm{W}$-lake trout, lake whitefish, northern pike, common shiner, spottail shiner, bluntnose minnow, blacknose dace, white sucker, tadpole madtom, burbot, trout-perch, rock bass, smallmouth bass, lowa darter. Johnny darter, yellow perch, log perch, walleye, mottled sculpin.

Beg Lake, $48^{\circ} 34^{\prime} \mathrm{N}, 91^{\circ} 22^{\prime} \mathrm{W}$-northern pike, blacknose shiner, spottail shiner, bluntnose minnow, longnose dace, white sucker, burbot. Johnny darter, walleye.

Pond between Beg and Bisk lakes, 48 $34^{\prime} \mathrm{N}, 91^{\circ} 21^{\prime} \mathrm{W}$-longnose dace, white sucker, walleye.

Bell Lake, $48^{\circ} 13^{\prime} \mathrm{N}, 91^{\circ} 07^{\prime} \mathrm{W}$-blackchin shiner, bluntnose minnow, green sunfish, black crappie.

Lake between Bell and Bit Lakes, $48^{\circ} 12^{\prime} \mathrm{N}, 91^{\circ} 09^{\prime} \mathrm{W}$-northern pike, blackchin shiner, bluntnose minnow.

Bentpine Creek, $48^{\circ} 26^{\prime} \mathrm{N}, 91^{\circ} 47^{\prime} \mathrm{W}$-blackchin shiner, white sucker, tadpole madtom, rock bass, yellow perch.

Bentpine Lake, $48^{\circ} 28^{\prime} \mathrm{N}, 91^{\circ} 47^{\prime} \mathrm{W}$-northern pike, rock bass, yellow perch, walleye.

Birch Lake, $48^{\circ} 04^{\prime} \mathrm{N}, 91^{\circ} 23^{\prime} \mathrm{W}$-lake trout, northern pike.

Bird Lake, $48^{\circ} 33^{\prime} \mathrm{N}, 91^{\circ} 21^{\prime} \mathrm{W}$-northern pike, walleye.

Bisk Lake, $48^{\circ} 35^{\prime} \mathrm{N}, 91^{\circ} 20^{\prime} \mathrm{W}$-northern pike, blacknose shiner, spottail shiner, mimic shiner, bluntnose minnow, fathead minnow, white sucker, trout-perch. Johnny darter, yellow perch, log perch, walleye.

Bit Lake, $48^{\circ} 12^{\prime} \mathrm{N}, 91^{\circ} 10^{\prime} \mathrm{W}-\mathrm{Walleye}$.

Lake between Bit and Other Man lakes, $48^{\circ} 12^{\prime} \mathrm{N}, 91^{\circ} 08^{\prime} \mathrm{W}$-blacknose shiner, bluntnose minnow, fathead minnow, green sunfish. lowa darter.

Brent Lake, $48^{\circ} 18^{\prime} \mathrm{N}, 91^{\circ} 40^{\prime} \mathrm{W}$-lake trout, cisco, northern pike, common shiner, blacknose shiner, mimic shiner, bluntnose minnow, largemouth bass, walleye, slimy sculpin. 
Brewer Lake, $48^{\circ} 17^{\prime} \mathrm{N}, 91^{\circ} 58^{\prime} \mathrm{W}$-lake whitefish. northern pike. shorthead redhorse. tadpole madtom, burbot, rock bass, smallmouth bass, walleye.

Brylcreme Lake, $48^{\circ} 34^{\prime} \mathrm{N}$. 91 $17^{\prime} \mathrm{W}$-cisco, lake whitefish, spottail shiner, mimic shiner. longnose dace, white sucker, shorthead redhorse, lowa darter, yellow perch, log perch. walleye.

River between Brylcreme and Buckingham lakes, $48^{\circ} 34^{\prime} \mathrm{N}$. 9 $1^{\circ} 17^{\prime} \mathrm{W}$-blacknose shiner, spottail shiner, bluntnose minnow, white sucker, pumpkinseed.

Buckingham Lake, 48 $33^{\prime} \mathrm{N}, 91^{\circ} 17^{\prime} \mathrm{W}$-lake trout, northern pike, mimic shiner, bluntnose minnow, pearl dace, white sucker. Johnny darter, yellow perch. walleye.

Bud Lake. $48^{\circ} 33^{\prime} \mathrm{N}, 91^{\circ} 21^{\prime} \mathrm{W}$-northern pike, walleye.

Burke Lake, $48^{\circ} 06^{\prime} \mathrm{N} .91^{\circ} 26^{\prime} \mathrm{W}$-lake trout, cisco, northern pike, rock bass. smallmouth bass, largemouth bass, walleye.

Burntside Lake, $48^{\circ} 30^{\prime} \mathrm{N}, 91^{\circ} 40^{\prime} \mathrm{W}$-lake trout, northern pike, golden shiner, common shiner, blacknose shiner, spottail shiner, bluntnose minnow, fathead minnow. white sucker, smallmouth bass, Iowa darter, Johnny darter, yellow perch, log perch, walleye. mottled sculpin.

Burt Lake, $48^{\circ} 18^{\prime} \mathrm{N}, 91^{\circ} 33^{\prime} \mathrm{W}$-lake trout, northern pike, largemouth bass, walleve.

Cache Bay (Saganaga Lake), $48^{\circ} 13^{\prime} \mathrm{N}, 91^{\circ} 01^{\prime} \mathrm{W}$-northern pike.

Cache Lake, $48^{\circ} 33^{\prime} \mathrm{N}, 91^{\circ} 03^{\prime} \mathrm{W}$-lake trout, northern pike.

Cache River, $48^{\circ} 32^{\prime} \mathrm{N}, 91^{\circ} 06^{\prime} \mathrm{W}$ - northern redbelly dace, lake chub, common shiner, pearl dace, white sucker, yellow perch.

Tributary to Cache River-9 $1^{\circ} 03^{\prime} \mathrm{N}, 48^{\circ} 31^{\prime} \mathrm{W}$ - burbot.

Cairn Lake, $48^{\circ} 23^{\prime} \mathrm{N}, 91^{\circ} 22^{\prime} \mathrm{W}$-northern pike. common shiner. bluntnose minnow. longnose dace, rock bass, lowa darter, Johnny darter, walleye, mottled sculpin.

Carp Lake, $48^{\circ} 06^{\prime} \mathrm{N}, 91^{\circ} 17^{\prime} \mathrm{W}$-lake trout, cisco, lake whitefish, northern pike, mimic shiner, white sucker, smallmouth bass, yellow perch, walleye.

Ceph Lake, $48^{\circ} 31^{\prime} \mathrm{N}, 91^{\circ} 43^{\prime} \mathrm{W}$ - northern pike, golden shiner, bluntnose minnow, tadpole madtom, pumpkinseed, smallmouth bass, walleye.

Chatterton Lake, $48^{\circ} 27^{\prime} \mathrm{N}$. $91^{\circ} 24^{\prime} \mathrm{W}$-northern pike, longnose dace. burbot. rock bass, Johnny darter, walleye, mottled sculpin.

Cirrus Lake, $48^{\circ} 37^{\prime} \mathrm{N}, 91^{\circ} 55^{\prime} \mathrm{W}$-lake trout, cisco. lake whitefish. northern pike. finescale dace, golden shiner, common shiner, blacknose shiner, spottail shiner, mimic shiner, bluntnose minnow, white sucker, trout-perch, green sunfish, black crappie, yellow perch, log perch, walleye, mottled sculpin, slimy sculpin. 
Cone Lake, $48^{\circ} 16^{\prime} \mathrm{N}, 91^{\circ} 44^{\prime} \mathrm{W}$-lake trout.

Conk Lake, $48^{\circ} 32^{\prime} \mathrm{N}, 91^{\circ} 46^{\prime} \mathrm{W}$ - northern pike, finescale dace, golden shiner. blacknose shiner, spottail shiner, mimic shiner, bluntnose minnow, longnose dace, white sucker, tadpole madtom, burbot, Iowa darter, Johnny darter, yellow perch, log perch, walleye, mottled sculpin.

Conmee Lake, $48^{\circ} 20^{\prime} \mathrm{N}, 91^{\circ} 39^{\prime} \mathrm{W}$ - northern pike, walleye.

Crooked Lake, $48^{\circ} 13^{\prime} \mathrm{N}, 91^{\circ} 46^{\prime} \mathrm{W}$ - silver lamprey, lake trout, cisco, lake whitefish, northern pike, northern redbelly dace, finescale dace, blacknose shiner, spottail shiner, mimic shiner, bluntnose minnow, white sucker, tadpole madtom, burbot, rock bass, bluegill, smallmouth bass, largemouth bass, black crappie, lowa darter, Johnny darter, yellow perch. log perch, walleye, mottled sculpin.

Cub Lake, $48^{\circ} 24^{\prime} \mathrm{N}, 91^{\circ} 25^{\prime} \mathrm{W}$-northern pike, walleye.

Cypress Lake, $48^{\circ} 11^{\prime} \mathrm{N}, 91^{\circ} 04^{\prime} \mathrm{W}$-lake trout, northern pike, smallmouth bass. walleye.

Dahlin Lake, $48^{\circ} 16^{\prime} \mathrm{N}, 91^{\circ} 54^{\prime} \mathrm{W}$-northern pike, northern redbelly dace, finescale dace, blacknose shiner, white sucker, rock bass, smallmouth bass, Iowa darter.

Darky Lake, $48^{\circ} 18^{\prime} \mathrm{N}, 91^{\circ} 47^{\prime} \mathrm{W}$ - lake trout, cisco, lake whitefish, northern pike, northern redbelly dace, golden shiner, emerald shiner, common shiner, blacknose shiner, mimic shiner, bluntnose minnow, white sucker, tadpole madtom. rock bass, green sunfish, pumpkinseed, longear sunfish, smallmouth bass, black crappie. Iowa darter, yellow perch, walleye.

Delahey Lake, $48^{\circ} 21^{\prime} \mathrm{N}, 91^{\circ} 32^{\prime} \mathrm{W}$-northern pike, walleye.

Dell Lake, $48^{\circ} 10^{\prime} \mathrm{N}, 91^{\circ} 28^{\prime} \mathrm{W}$ - northern redbelly dace, finescale dace, longnose dace, white sucker, largemouth bass, Iowa darter, Johnny darter, yellow perch. mottled sculpin.

Lake between Dell and Isabella lakes, $48^{\circ} 10^{\prime} \mathrm{N}, 91^{\circ} 29^{\prime} \mathrm{W}$ - cisco, white sucker, rock bass, largemouth bass, Iowa darter, Johnny darter, yellow perch.

Doc Lake, $48^{\circ} 12^{\prime} \mathrm{N}, 91^{\circ} 42^{\prime} \mathrm{W}$-northern pike.

Doré Lake, $48^{\circ} 36^{\prime} \mathrm{N}, 91^{\circ} 26^{\prime} \mathrm{W}$-lake trout, northern pike.

Draper Lake, $48^{\circ} 32^{\prime} \mathrm{N}, 91^{\circ} 37^{\prime} \mathrm{W}$ - lake trout, northern pike, walleye.

East Lake, $48^{\circ} 10^{\prime} \mathrm{N}, 91^{\circ} 23^{\prime} \mathrm{W}$-smallmouth bass, walleye.

Edge Lake, $48^{\circ} 14^{\prime} \mathrm{N}, 91^{\circ} 15^{\prime} \mathrm{W}$ - northern pike.

Elizabeth Lake, $48^{\circ} 34^{\prime} \mathrm{N}, 91^{\circ} 33^{\prime} \mathrm{W}$ - northern pike, walleye.

Elk Lake, $48^{\circ} 15^{\prime} \mathrm{N}, 91^{\circ} 45^{\prime} \mathrm{W}$-lake trout. 
Emerald Lake, $48^{\circ} 08^{\prime} \mathrm{X}$. $91^{\circ} 15^{\prime} \mathrm{W}$ - lake trout, bluntnose minnow. Lowa darter, yellow perch. slinyy sculpin.

Era Lake, $48^{\circ} 43^{\prime} \mathrm{N}, 91^{\circ} 11^{\prime} \mathrm{W}$ - (included because it is immediately outside QPP and tributary to French Lake)-lake sturgeon, lake trout, cisco, lake whitefish, rainbow smelt, northern pike, white sucker, smallmouth bass.

Ferguson Lake. $48^{\circ} 29^{\prime} \mathrm{N}, 91^{\circ} 10^{\prime} \mathrm{W}$-lake trout. northern pike.

Fern Lake, $48^{\circ} 33^{\prime} \mathrm{N}, 91^{\circ} 21^{\prime} \mathrm{W}$ - northern pike, smallmouth bass, walleye.

Fred Lake, $48^{\circ} 37^{\prime} \mathrm{N}, 91^{\circ} 32^{\prime} \mathrm{W}$-northern pike, walleye.

French Lake. $48^{\circ} 40^{\prime} \mathrm{N}, 91^{\circ} 09^{\prime} \mathrm{W}$-lake trout, cisco, lake whitefish, rainbow smelt, northern pike, emerald shiner, spottail shiner, mimic shiner, bluntnose minnow. fathead minnow, white sucker, shorthead redhorse, burbot, smallmouth bass. Johnny darter, yellow perch, log perch, walleye.

French River. $48^{\circ} 39^{\prime} \mathrm{N} .91^{\circ} 10^{\prime} \mathrm{W}$ - northern pike. common shiner, mimic shiner. white sucker. Johnny darter. log perch.

Gardner Bay (Crooked Lake), 48 $14^{\prime} \mathrm{N}, 91^{\circ} 45^{\prime} \mathrm{W}$ - cisco, lake whitefish, northern pike. blacknose shiner. mimic shiner, bluntnose minnow, tadpole madtom. rock bass, smallmouth bass, largemouth bass. lowa darter, yellow perch. log perch, walleye.

Glacier Lake. $48^{\circ} 13^{\prime} \mathrm{N} .91^{\circ} 14^{\prime} \mathrm{W}$-lake trout, smallmouth bass, walleye.

Gratton Lake, $48^{\circ} 18^{\prime} \mathrm{N}, 91^{\circ} 52^{\prime} \mathrm{W}$-northern redbelly dace, white sucker, tadpole madtom, largemouth bass, lowa darter, yellow perch.

Grey Lake. $48^{\circ} 12^{\prime} \mathrm{N}, 91^{\circ} 27^{\prime} \mathrm{W}$ - smallmouth bass, largemouth bass.

Heronshaw Lake, $48^{\circ} 27^{\prime} \mathrm{N}, 91^{\circ} 22^{\prime} \mathrm{W}$-northern pike, walleye.

Hop Lake, $48^{\circ} 40^{\prime}$ N. $91^{\circ} 02^{\prime} \mathrm{W}$-brook trout, (suckers?).

How ard Lake. $48^{\circ} 36^{\prime} \mathrm{N}, 91^{\circ} 13^{\prime} \mathrm{W}$-northern pike.

Isabella Lake, $48^{\circ} 10^{\prime} \mathrm{N}, 91^{\circ} 31^{\prime} \mathrm{W}$-northern pike. mimic shiner, white sucker, smallmouth bass, largemouth bass, yellow perch, walleye.

Stream between Isabella Lake and North Bay (Basswood Lake), $48^{\circ} 10^{\prime} \mathrm{N}$. $91^{\circ} 28^{\prime} \mathrm{W}$-blackchin shiner, longnose dace. pumpkinseed, longear sunfish, smallmouth bass, largemouth bass, lowa darter, Johnny darter.

Jack Lake. $48^{\circ} 29^{\prime} \mathrm{N}, 91^{\circ} 48^{\prime} \mathrm{W}$-northern pike, burbot, Johnny darter, yellow perch. walleye.

Jean Lake, $48^{\circ} 32^{\prime} \mathrm{N}, 91^{\circ} 46^{\prime} \mathrm{W}$-lake trout. northern pike. spottail shiner, mimic shiner, bluntnose minnow, longnose dace, white sucker, tadpole madtom, rock bass, bluegill, smallmouth bass, largemouth bass, lowa darter, Johnny darter. yellow perch, walleye. 
Jeff Lake, $48^{\circ} 10^{\prime} \mathrm{N}, 91^{\circ} 25^{\prime} \mathrm{W}$ - lake trout, northern pike, smallmouth bass. Jessie Lake, $48^{\circ} 35^{\prime} \mathrm{N}, 91^{\circ} 36^{\prime} \mathrm{W}$ - northern pike, walleye. Joyce Lake, $48^{\circ} 17^{\prime} \mathrm{N}, 91^{\circ} 30^{\prime} \mathrm{W}$-lake trout, northern pike, walleye.

Kahshahpiwi Lake, $48^{\circ} 14^{\prime} \mathrm{N}, 91^{\circ} 29^{\prime} \mathrm{W}$-lake trout, northern pike, smallmouth bass, walleye.

Kasakokwog Lake, $48^{\circ} 38^{\prime} \mathrm{N}, 91^{\circ} 5 \mathrm{l}^{\prime} \mathrm{W}$ - cisco, northern pike, golden shiner, blacknose shiner, mimic shiner, longnose dace, white sucker. Johnny darter, yellow perch, walleye, mottled sculpin.

Kawnipi Lake, $48^{\circ} 24^{\prime} \mathrm{N}, 91^{\circ} 15^{\prime} \mathrm{W}$-silver lamprey, lake trout, northern pike, finescale dace, common shiner, Johnny darter, yellow perch, log perch, walleye.

Keats Lake, $48^{\circ} 27^{\prime} \mathrm{N}, 91^{\circ} 24^{\prime} \mathrm{W}$-northern pike, walleye.

Keefer Lake, $48^{\circ} 18^{\prime} \mathrm{N}, 91^{\circ} 27^{\prime} \mathrm{W}$-lake trout, northern pike, walley'e.

Kenny Lake, $48^{\circ} 20^{\prime} \mathrm{N}, 91^{\circ} 08^{\prime} \mathrm{W}$-northern pike, walleye.

Kett Lake, $48^{\circ} 09^{\prime} \mathrm{N}, 91^{\circ} 38^{\prime} \mathrm{W}$-lake trout, northern pike.

Knife Lake, $48^{\circ} 07^{\prime} \mathrm{N}, 91^{\circ} 12^{\prime} \mathrm{W}$-lake trout, northern pike, smallmouth bass, walleye.

Lac la Croix, $48^{\circ} 19^{\prime} \mathrm{N}, 92^{\circ} 06^{\prime} \mathrm{W}$ - silver lamprey, lake sturgeon, lake trout, cisco, lake whitefish, northern pike, white sucker, shorthead redhorse, silver redhorse, burbot, rock bass, smallmouth bass, black crappie, yellow perch, sauger, walleye.

Lakin Lake, $48^{\circ} 36^{\prime} \mathrm{N}, 91^{\circ} 44^{\prime} \mathrm{W}$-northern pike, golden shiner, common shiner, bluntnose minnow, lowa darter, Johnny darter, yellow perch.

Lily Pad Lake, $48^{\circ} 13^{\prime} \mathrm{N}, 91^{\circ} 04^{\prime} \mathrm{W}$ - northern pike, smallmouth bass, walleye.

Little Roland Lake, $48^{\circ} 15^{\prime} \mathrm{N}, 91^{\circ} 53^{\prime} \mathrm{W}$-lake whitefish, northern pike, mimic shiner, white sucker, shorthead redhorse, rock bass, longear sunfish, smallmouth bass, lowa darter, yellow perch.

Lonely Lake, $48^{\circ} 32^{\prime} \mathrm{N}, 91^{\circ} 34^{\prime} \mathrm{W}$ - silver lamprey, northern pike, longnose dace, lowa darter, smallmouth bass, walleye.

Lost Bay (Basswood Lake), $48^{\circ} 09^{\prime} \mathrm{N}, 91^{\circ} 30^{\prime} \mathrm{W}$-pumpkinseed, bluegill.

Louisa Lake, $48^{\circ} 08^{\prime} \mathrm{N}, 91^{\circ} 20^{\prime} \mathrm{W}$-lake trout, cisco, northern pike, golden shiner, white sucker, lowa darter, yellow perch, slimy sculpin.

Lynx Lake, $48^{\circ} 32^{\prime} \mathrm{N}, 91^{\circ} 53^{\prime} \mathrm{W}$ - northern pike, golden shiner, pumpkinseed, lowa darter, yellow perch.

Mack Lake, $48^{\circ} 23^{\prime} \mathrm{N}, 91^{\circ} 00^{\prime} \mathrm{W}$-northern pike, northern redbelly dace, mimic shiner, bluntnose minnow, white sucker, largemouth bass, yellow perch, walleye. 
Maligne Riser, $48^{\circ} 23^{\prime} \mathrm{N}, 91^{\circ} 53^{\prime} \mathrm{W}$ - smallmouth bass.

Maria Lake, $48^{\circ} 36^{\prime} \mathrm{N}, 91^{\circ} 33^{\prime} \mathrm{W}$-northern pike. walleye.

MeAlpine Lake, $48^{\circ} 37^{\prime} \mathrm{N}, 91^{\circ} 36^{\prime} \mathrm{W}$ - lake trout. northern redbelly dace, blacknose shiner, longnose dace, pearl dace, white sucker. Iowa darter, walleye.

McArec Lake, $48^{\circ} 18^{\prime} \mathrm{N}$. 91 $1^{\circ} 54^{\prime} \mathrm{W}$-lake trout, cisco, lake whitefish, northern pike, finescale dace, blacknose shiner, bluntnose minnow, longnose dace, white sucker, shorthead redhorse, tadpole madtom, burbot. rock bass, pumpkinseed. smallmouth bass, lowa darter, Johnny darter, yellow perch, log perch, walleye, mottled sculpin.

McDongall Lake, $48^{\circ} 27^{\prime} \mathrm{N}, 91^{\circ} 27^{\prime} \mathrm{W}$ - lake trout, northern pike.

McEwen Lake, $48^{\circ} 17^{\prime} \mathrm{N}, 91^{\circ} 10^{\prime} \mathrm{W}$-lake trout, northern pike, smallmouth bass, walleye.

McIntyre Lake, $48^{\circ} 15^{\prime} \mathrm{N}, 91^{\circ} 37^{\prime} \mathrm{W}$-lake trout, northern pike, walleye.

Mckenzie Bay (Kawnipi Lake), $48^{\circ} 25^{\prime} \mathrm{N}, 91^{\circ} 1 \mathrm{I}^{\prime} \mathrm{W}$-northern pike, finescale dace. common shiner, Johnny darter, yellow perch, log perch, walleye.

McNaught Lake, $48^{\circ} 09^{\prime} \mathrm{N} .91^{\circ} 35^{\prime} \mathrm{W}$ - cisco, northern pike, white sucker, bluegill, largemouth bass.

McNiece Lake, $48^{\circ} 14^{\prime} \mathrm{N}, 91^{\circ} 27^{\prime} \mathrm{W}$-lake trout, northern pike.

Meadows Lake, $48^{\circ} 06^{\prime} \mathrm{N}, 91^{\circ} 23^{\prime} \mathrm{W}$-green sunfish, smallmouth bass, largemouth bass, black crappie. Iowa darter.

Merrian Bay (Basswood Lake), 48 $05^{\prime} \mathrm{N}, 91^{\circ} 32^{\prime} \mathrm{W}$ - northern pike.

Middle Roland Lake, $48^{\circ} 15^{\prime} \mathrm{N}, 91^{\circ} 51^{\prime} \mathrm{W}$ - cisco, northern pike, mimic shiner, white sucker, smallmouth bass, lowa darter, yellow perch, mottled sculpin.

Minn Lake, $48^{\circ} 21^{\prime} \mathrm{N}, 91^{\circ} 53^{\prime} \mathrm{W}$-lake whitefish, northern pike, common shiner, blacknose shiner, bluntnose minnow, longnose dace, white sucker, shorthead redhorse. rock bass, smallmouth bass, Iowa darter, Johnny darter, yellow perch, walleye.

Murdock Lake, $48^{\circ} 21^{\prime} \mathrm{N}, 91^{\circ} 16^{\prime} \mathrm{W}$-northern pike, walleye.

Nest Lake, $48^{\circ} 09^{\prime} \mathrm{N}, 91^{\circ} 16^{\prime} \mathrm{W}$-lake trout.

No Man Lake. $48^{\circ} 09^{\prime} \mathrm{N}, 91^{\circ} 16^{\prime} \mathrm{W}$-northern pike, bluntnose minnow, fathead minnow, blacknose dace, $\log$ perch, walleye.

Noon Lake, $48^{\circ} 12^{\prime} \mathrm{N}, 91^{\circ} 24^{\prime} \mathrm{W}$-smallmouth bass, largemouth bass.

North Bay (Basswood Lake), $48^{\circ} 09^{\prime} \mathrm{N}, 91^{\circ} 29^{\prime} \mathrm{W}$-northern pike, white sucker, rock bass, bluegill, longear sunfish, largemouth bass, walleye.

Olifaunt Lake, $48^{\circ} 32^{\prime} \mathrm{N}, 91^{\circ} 26^{\prime} \mathrm{W}$-lake trout, northern pike, smallmouth bass, walleye. 
Omeme Lake, $48^{\circ} 30^{\prime} \mathrm{N}, 92^{\circ} 00^{\prime} \mathrm{W}$-cisco, northern pike, northern redbelly dace, blacknose shiner, mimic shiner, bluntnose minnow, burbot, lowa darter, Johnny darter, yellow perch, walleye, mottled sculpin.

Oriana Lake, $48^{\circ} 35^{\prime} \mathrm{N} .91^{\circ} 41^{\prime} \mathrm{W}$ - lake trout, northern pike, longnose dace. white sucker, burbot, rock bass, largemouth bass, lowa darter, Johnny darter, yellow perch, walleye.

Other Man Lake, $48^{\circ} 12^{\prime} \mathrm{N}, 91^{\circ} 09^{\prime} \mathrm{W}$-lake trout, northern pike. northern redbelly dace, common shiner, blacknose shiner, white sucker, green sunfish, Iowa darter, walleye.

Pickerel Lake, $48^{\circ} 37^{\prime} \mathrm{N}, 91^{\circ} 18^{\prime} \mathrm{W}$-lake trout. cisco, lake whitefish, northern pike, blacknose shiner, mimic shiner, bluntnose minnow, white sucker, burbot, smallmouth bass. Johnny darter, yellow perch, sauger, walleye.

River from Pickerel Lake to Bisk Lake, $48^{\circ} 35^{\prime} \mathrm{N}, 91^{\circ} 20^{\prime} \mathrm{W}$-blacknose shiner, spottail shiner, mimic shiner, bluntnose minnow, longnose dace, white sucker, trout-perch, smallmouth bass, yellow perch, log perch, walleye, slimy sculpin.

Pickerel River, $48^{\circ} 39^{\prime} \mathrm{N}, 91^{\circ} 10^{\prime} \mathrm{W}$-northern pike, common shiner, spottail shiner, mimic shiner, white sucker, Johnny darter, yellow perch, log perch, walleye.

Plough Lake, $48^{\circ} 09^{\prime} \mathrm{N}, 91^{\circ} 11^{\prime} \mathrm{W}$-lake trout, northern pike.

Poacher Lake, $48^{\circ} 05^{\prime} \mathrm{N}, 91^{\circ} 24^{\prime} \mathrm{W}$-lake trout, northern pike.

Point Lake, $48^{\circ} 10^{\prime} \mathrm{N}, 91^{\circ} 32^{\prime} \mathrm{W}$ - northern pike, smallmouth bass.

Pond Lake, $48^{\circ} 18^{\prime} \mathrm{N}, 91^{\circ} 54^{\prime} \mathrm{W}$ - lake trout, cisco, lake whitefish, blacknose shiner, mimic shiner, bluntnose minnow, Johnny darter. log perch, mottled sculpin.

Poolhbah Lake, $48^{\circ} 22^{\prime} \mathrm{N}, 91^{\circ} 43^{\prime} \mathrm{W}$ - lake trout, northern pike, blacknose shiner. longnose dace. tadpole madtom, rock bass. Iowa darter. Johnny darter, yellow perch, walleye.

Pulling Lake, $48^{\circ} 16^{\prime} \mathrm{N}, 91^{\circ} 54^{\prime} \mathrm{W}$ - cisco, white sucker, tadpole madtom, rock bass, smallmouth bass, largemouth bass, lowa darter, mottled sculpin.

Quetico Lake, $48^{\circ} 34^{\prime} \mathrm{N}, 91^{\circ} 54^{\prime} \mathrm{W}$ - lake trout, cisco, lake whitefish, northern pike, northern redbelly dace, finescale dace, golden shiner, emerald shiner, common shiner, blackchin shiner, blacknose shiner, spottail shiner, mimic shiner. bluntnose minnow, blacknose dace, longnose dace, white sucker, shorthead redhorse, tadpole madtom, trout-perch, rock bass, longear sunfish, smallmouth bass, largemouth bass, lowa darter, Johnny darter, yellow perch, log perch, walleye, mottled sculpin.

Ram Lake, $48^{\circ} 33^{\prime} \mathrm{N}, 91^{\circ} 31^{\prime} \mathrm{W}$-lake trout, northern pike.

Ranger Bay (Basswood Lake), 48 $07^{\prime} \mathrm{N}, 91^{\circ} 36^{\prime} \mathrm{W}$ - lake trout. northern pike, smallmouth bass, walleye. 
Rawn Lake, $48^{\circ} 34^{\prime} \mathrm{N} .91^{\circ} 15^{\prime} \mathrm{W}$-lake trout. northern pike, blacknose shmer. spottal shiner, mimic shiner, white sucker, yellow perch, walleye.

River to Rawn Lake, 48 35’ N, 91 $07^{\prime} \mathrm{W}$-northern pike, golden shiner, blacknose shmer. pearl dace, white sucker.

Robin Lake, $48^{\circ} 32^{\prime} \mathrm{N} .91^{\circ} 54^{\prime} \mathrm{W}^{\prime}$ - cisco, northern pike, blacknose dace, longnose dace, white sucher. pumpkinseed. Iowa darter. vellow perch. walleye.

Robiuson Lake, $48^{\circ} 11^{\prime} \mathrm{N}, 91^{\circ} 40^{\prime} \mathrm{W}^{\prime}$-lake trout. cisco. lake whitefish, northern pike. blacknose shiner, mimic shiner, bluntnose minnow. longnose dace, white sucker. tadpole madtom. rock bass. smallmouth bass. largemouth bass. lowa darter. Johnny darter. yellow perch, walleye.

Roland Lake. $48^{\circ} 16^{\prime} \mathrm{N} .91^{\circ} 51^{\prime} \mathrm{W}$-lake trout, northern pike, white sucker. Iowa darter. yellow perch. walleye.

Rouge Lake, $48^{\circ} 29^{\prime}$ N. $91^{\circ} 43^{\prime} \mathrm{W}$-northern pike. golden shiner. common shiner, blackchin shiner, mimic shiner, bluntnose minnow. longnose dace, white sucker. tadpole madtom. burbot. rock bass. longear sunfish, smallmouth bass. Johnny darter. yellow perch. log perch, walleye. mottled sculpin.

Russell Lake, $48^{\circ} 29^{\prime} \mathrm{N} .91^{\circ} 30^{\prime} \mathrm{W}$-northern pike. mimic shiner, bluntnose minnow. Johnny darter. walleye.

Saganaga Lake. $48^{\circ} 13^{\prime} \mathrm{N} .90^{\circ} 59^{\prime} \mathrm{W}$-silver lamprey, lake trout. lake whitefish. northern pike, smallmouth bass, walleye.

Saganagons Lake, $48^{\circ} 18^{\prime} \mathrm{N}, 91^{\circ} 00^{\prime} \mathrm{W}$-lake trout, northern pike, walleye.

Sarah Lake. $48^{\circ} 12^{\prime} \mathrm{N} .91^{\circ} 35^{\prime} \mathrm{W}$-lake trout, northern pike. smallmouth bass. largemouth bass. walleye.

Sark Lake, $48^{\circ} 21^{\prime} \mathrm{N}, 91^{\circ} 26^{\prime} \mathrm{W}$-lake trout, northern pike, walleye.

Shade Lake, $48^{\circ} 10^{\prime} \mathrm{N}, 91^{\circ} 27^{\prime} \mathrm{W}$ - lake trout, northern pike, bluntnose minnow, longnose dace. white sucker, rock bass, smallmouth bass. largemouth bass. Johnny darter, yellow perch. walleye, slimy sculpin.

Shelle! Lake. $48^{\circ} 27^{\prime} \mathrm{X} .91^{\circ} 21^{\prime} \mathrm{W}$ - northern pike. Johnny darter, walleye, mottled sculpin.

Sheridan Lake, $48^{\circ} 06^{\prime} \mathrm{N}, 91^{\circ} 20^{\prime} \mathrm{W}$-lake trout, northern pike.

Side Lake, $48^{\circ} 11^{\prime} \mathrm{N} .91^{\circ} 32^{\prime} \mathrm{W}$-lake trout, northern pike.

Silence Lake, $48^{\circ} 14^{\prime} \mathrm{N}, 91^{\circ} 23^{\prime} \mathrm{W}$-lake trout, cisco, lake whitefish, northern pike. finescale dace, common shiner, blacknose shiner, bluntnose minnow. longnose dace, white sucker, rock bass, smallmouth bass. largemouth hass, lowa darter. Johnny darter, yellow perch, walleye.

Lake above Silence Lake, $48^{\circ} 12^{\prime} \mathrm{N}, 91^{\circ} 24^{\prime} \mathrm{W}$-blacknose shiner. mimic shiner, bluntnose minnow, white sucker. lowa darter. Johnny darter, yellow perch.

Silver Falls River, $48^{\circ} 14^{\prime} \mathrm{N}, 91^{\circ} 45^{\prime} \mathrm{W}$ - northern pike, walleye. 
Slate Lake, $48^{\circ} 15^{\prime} \mathrm{N}, 91^{\circ} 06^{\prime} \mathrm{W}$ - northern pike. rock bass, smallmouth bass. walleye.

Smally Lake, $48^{\circ} 39^{\prime}$ N. $91^{\circ} 46^{\prime} \mathrm{W}$ - northern redbelly dace, finescale dace, bluntnose minnow, fathead minnow, green sunfish, largemouth bass.

Soho Lake, $48^{\circ} 39^{\prime} \mathrm{N}, 91^{\circ} 45^{\prime} \mathrm{W}$ - lake trout, northern pike, bluntnose minnow, lowa darter, walleye.

Sturgeon Lake, $48^{\circ} 28^{\prime} \mathrm{N}, 91^{\circ} 37^{\prime} \mathrm{W}$-lake sturgeon, lake trout, cisco, lake whitefish, northern pike, finescale dace, spottail shiner, mimic shiner, bluntnose minnow, white sucker, shorthead redhorse, burbot, rock bass, smallmouth bass. lowa darter, Johnny darter, yellow perch. walleye.

Sucker Lake, $48^{\circ} 03^{\prime} \mathrm{N}, 91^{\circ} 26^{\prime} \mathrm{W}$-northern pike. walley'e.

Sultry Lake, $48^{\circ} 13^{\prime} \mathrm{N}, 91^{\circ} 22^{\prime} \mathrm{W}$ - northern pike, walleye.

Summer Lake, $48^{\circ} 12^{\prime} \mathrm{N}, 91^{\circ} 24^{\prime} \mathrm{W}$-lake trout, northern pike, bluntnose minnow, white sucker, lowa darter, Johnny darter, yellow perch, walleye.

Sunday Lake, $48^{\circ} 06^{\prime} \mathrm{N}, 91^{\circ} 26^{\prime} \mathrm{W}$-lake trout, cisco, lake whitefish, northern pike, mimic shiner, bluntnose minnow, white sucker, rock bass, green sunfish. longear sunfish, smallmouth bass, largemouth bass, black crappie, walleye.

Tammer Lake, $48^{\circ} 23^{\prime} \mathrm{N}, 91^{\circ} 50^{\prime} \mathrm{W}$-northern pike, walleye.

Ted Lake, $48^{\circ} 15^{\prime} \mathrm{N}, 91^{\circ} 41^{\prime} \mathrm{W}$-lake trout, walleye.

That Man Lake, $48^{\circ} 07^{\prime} \mathrm{N}, 91^{\circ} 16^{\prime} \mathrm{W}$-lake trout, northern pike, common shiner. blacknose shiner, bluntnose minnow, fathead minnow, blacknose dace, pearl dace, white sucker, green sunfish, smallmouth bass, black crappie, lowa darter, walleye.

This Man Lake, $48^{\circ} 10^{\prime} \mathrm{N}, 91^{\circ} 13^{\prime} \mathrm{W}$-lake trout, finescale dace, blacknose dace. white sucker, green sunfish, black crappie, walleye.

Tilly Lake, $48^{\circ} 37^{\prime} \mathrm{N}, 90^{\circ} 58^{\prime} \mathrm{W}$-lake trout, northern pike.

Trant Lake, $48^{\circ} 17^{\prime} \mathrm{N}, 91^{\circ} 26^{\prime} \mathrm{W}$ - largemouth bass.

Trouser Lake, $48^{\circ} 36^{\prime} \mathrm{N}, 91^{\circ} 05^{\prime} \mathrm{W}$-northern pike.

Tuck Lake, $48^{\circ} 14^{\prime} \mathrm{N}, 91^{\circ} 33^{\prime} \mathrm{W}$-lake trout, northern pike, walleye.

Vermon Lake, $48^{\circ} 22^{\prime} \mathrm{N}, 91^{\circ} 30^{\prime} \mathrm{W}$-northern pike, walleye.

Wawiag River, $48^{\circ} 25^{\prime} \mathrm{N}, 91^{\circ} 01^{\prime} \mathrm{W}$-mooneye, walleye.

Walter Lake, $48^{\circ} 32^{\prime} \mathrm{N}, 91^{\circ} 36^{\prime} \mathrm{W}$-lake trout, northern pike, bluntnose minnow. rock bass, smallmouth bass, lowa darter. Johnny darter, log perch, walleye. mottled sculpin.

West Bay (Quetico Lake), $48^{\circ} 3 \mathrm{I}^{\prime} \mathrm{N}, 92^{\circ} 02^{\prime} \mathrm{W}$-northern pike, walleye. 
West I.ake, $48^{\circ} 11^{\prime} \mathrm{N} .91^{\circ} 28^{\prime} \mathrm{H}$ - northern pike, white sucker, largemouth bass. walleve.

Wet I.ake. $48^{\circ} 18^{\prime} \mathrm{X}, 91^{\circ} 08^{\prime} \mathrm{W}^{\prime}$-northern pike, walleye.

Wicksteed Lake. $48^{\circ} 18^{\prime} \mathrm{N}$, 9 $1^{\circ} 52^{\prime} \mathrm{W}$-northern pike, mortherm redbelly dace. blacknose shiner, bluntnose nrinnow, white sucker. tadpole madtom, rock bass. pumphimseed. lowa darter. Jolinity darter, yellow perch, log perch.

Wild Goose Lake, $48^{\circ} 28^{\prime} \mathrm{N} .91^{\circ} 56^{\prime} \mathrm{W}$-northern pike, walleye.

Windigoostigwan Lake, $48^{\circ} 40^{\prime} \mathrm{N}$. $91^{\circ} 00^{\prime} \mathrm{W}$ - northern pike, spottail shiner, mimuc shiner, white sucker, yellow perch.

Wokele! Lake, $48^{\circ} 28^{\prime} \mathrm{N}$. $92^{\circ} 02^{\prime} \mathrm{W}$-northern pike, finescale dace, spottail shiner, mimic shiner, bluntnose minnow, white sucker, burbot. smallmouth bass. lowa darter. Johnny darter, yellow perch. log perch. walleye. mottled sculpin.

Veh Lake, $48^{\circ} 31^{\prime} \mathrm{N} .91^{\circ} 38^{\prime} \mathrm{W}$-northern pike. bluntnose minnow, white sucker. tadpole madtom, pumpkinseed. longear sunfish, largemouth bass. Iowa darter, yellow perch, walleye.

Your Lake, $48^{\circ} 28^{\prime} \mathrm{N}, 91^{\circ} 51^{\prime} \mathrm{W}$ - northern pike, golden shiner, blacknose shiner, mimic shiner. bluntnose minnow. rock bass, pumpkinseed. yellow perch, walleve.

Yum Yum Lake, $48^{\circ} 12^{\prime} \mathrm{N} .91^{\circ} 28^{\prime} \mathrm{W}$-lake trout. northern pike, bluntnose minnow, smallmouth bass, walleye.

River to Lindsay Lake, $48^{\circ} 30^{\prime} \mathrm{N}, 91^{\circ} 01^{\prime} \mathrm{W}$-white sucker.

Creek from Little Eva Lake at Hwy No. 11, 48 $40^{\prime} \mathrm{N}, 90^{\circ} 58^{\prime} \mathrm{W}$ - pearl dace.

Lake on Irving Island, $48^{\circ} 17^{\prime}$ N. $91^{\circ} 57^{\prime} \mathrm{W}$-northern pike, smallmouth bass.

\section{Quetico Forestry Plan Lakes-see p. ix for explanation.}

Lake 1 Block $1,48^{\circ} 31^{\prime} \mathrm{N}, 92^{\circ} 03^{\prime} \mathrm{W}$-northern pike, white sucker, yellow perch, walleye.

Lake 1 Block 2. $48^{\circ} 34^{\prime} \mathrm{N}, 91^{\circ} 54^{\prime} \mathrm{W}$ - northern pike, bluntnose minnow, white sucker, burbot. largemouth bass. lowa darter.

Lake 3 Block 2, 48 36’ $\mathrm{N}, 91^{\circ} 50^{\prime} \mathrm{W}$-northern pike, golden shiner, blacknose shiner, mimic shiner, bluntnose minnow, white sucker, burbot, rock bass. longear sunfish, yellow perch, walleye, mottled sculpin.

Lake 5 Block 2. $48^{\circ} 36^{\prime} \mathrm{N}, 91^{\circ} 45^{\prime} \mathrm{W}$ - blacknose shiner, bluntnose minnow, white sucker. pumpkinseed, lowa darter, Johnny darter, yellow perch. 
Lake 6 Block $2,48^{\circ} 34^{\prime} \mathrm{N}, 91^{\circ} 44^{\prime} \mathrm{W}$ - cisco, northern pike, common shiner. longnose dace, white sucker. tadpole madtom, Johnny darter, yellow perch, log perch.

Lake 11 Block 2, 48 $33^{\prime} \mathrm{N}, 91^{\circ} 50^{\prime} \mathrm{W}$-northern pike, rock bass, pumpkinseed, yellow perch.

Lake 7 Block 5, 48 $17^{\prime} \mathrm{N}, 91^{\circ} 46^{\prime} \mathrm{W}$-northern pike, bluntnose minnow. white sucker, rock bass, green sunfish, Johnny darter, walleye.

Lake 8 Block 5, $48^{\circ} 17^{\prime} \mathrm{N}, 91^{\circ} 46^{\prime} \mathrm{W}$ - lake trout, northern redbelly dace, white sucker, lowa darter.

Lake 16 Block 5, $48^{\circ} 16^{\prime} \mathrm{N}, 91^{\circ} 49^{\prime} \mathrm{W}$-northern redbelly dace, finescale dace, creek chub, white sucker, lowa darter, yellow perch.

Lake 25 Block $5,48^{\circ} 15^{\prime} \mathrm{N}, 92^{\circ} 00^{\prime} \mathrm{W}$-northern pike. bluntnose minnow, blacknose dace, white sucker, tadpole madtom, yellow perch. log perch.

Lake 30 Block 5, 48 $18^{\prime} \mathrm{N}, 91^{\circ} 46^{\prime} \mathrm{W}$-lake sturgeon, northern pike. northern redbelly dace, common shiner, bluntnose minnow, fathead minnow, white sucker, shorthead redhorse, rock bass, pumpkinseed, smallmouth bass, Johnny darter, walleye, mottled sculpin.

Lake 78 Block 8, $48^{\circ} 11^{\prime} \mathrm{N}, 91^{\circ} 39^{\prime} \mathrm{W}$-lake whitefish, mimic shiner, longnose dace, white sucker, tadpole madtom, rock bass, bluegill, smallmouth bass, walleye.

Lake 64 Block $10,48^{\circ} 20^{\prime} \mathrm{N}, 91^{\circ} 09^{\prime} \mathrm{W}$-northern pike, walleye.

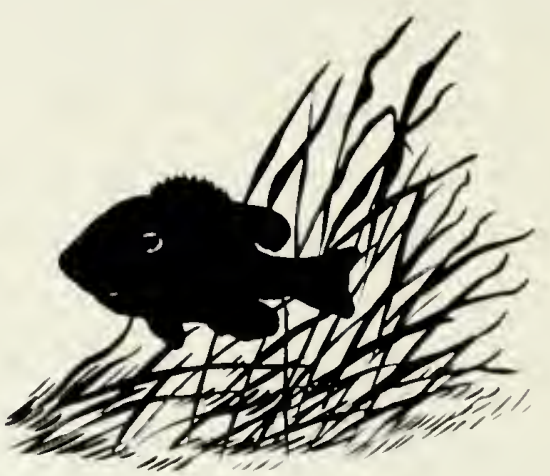




\section{History of Quetico Fishes}

\section{Glacial History and Changes in Pathways for Fishes}

The waters of Quetico at present flow westward to Lake Winnipeg, northward to the Nelson River, and eventually to Hudson Bay. Today these northwardflowing Quetico-Hudson Bay waters have no connection with the nearly eastward-flowing Great Lakes-Atlantic waters and the southward-flowing Mississippi-Gulf of Mexico waters (see Fig. 2A). This was not always so.

Just over 14.000 years ago there were no freshwater fishes in eastern Canada, nor were there any habitats for them, as the land lay deeply buried in glacial ice. During the glacial periods fishes now common in Ontario occurred in the unglaciated Mississippi system. About 14,000 years ago the earliest fresh water in Ontario was an impoundment of melt water at the face of the receding glacier, which drained southward by a connection to the Mississippi River. This is represented today by the southwestern tip of Lake Erie. Quetico was still beneath the front of the receding glacier 12,700 years ago (Fig. 2B). There were two large impoundments nearby, Lake Agassiz, over what is now the Red River, and Lake Keweenaw, over what is now the western tip of Lake Superior. Both of these impoundments were connected to the Mississippi River and drained south. No doubt those species of fishes in the upper Mississippi system which were adapted to cold lake waters quickly invaded these new habitats to the north.

By 12.400 years ago the glacier had exposed Quetico, which was then connected to the Mississippi by Lake Agassiz (Fig. 2C). Fishes could then invade what are now the lakes and streams of Quetico. By 9,500 years ago (Fig. 2D) the glacier had retreated to the extent that land levels and direction of stream flow were changing. The Red River, now isolated from the Mississippi system, flowed north into Lake Agasssiz. Lake Agassiz, with Quetico waters as a tributary. drained eastward in to the Great Lakes, thus providing access to Quetico to fishes which, 3,000 years earlier, had moved into the developing Great Lakes. By 8,400 years ago the connection with the Great Lakes had gone, and Quetico and a much reduced Lake Agassiz were draining toward the north. About 7.300 years ago the ice had retreated to the extent that Hudson Bay was formed: Quetico then became the easternmost part of what is now the Nelson River segment of the Hudson Bay watershed (Fig. 2A). A more detailed account is available in Elson (1967) and Eddy et al. (1972). 


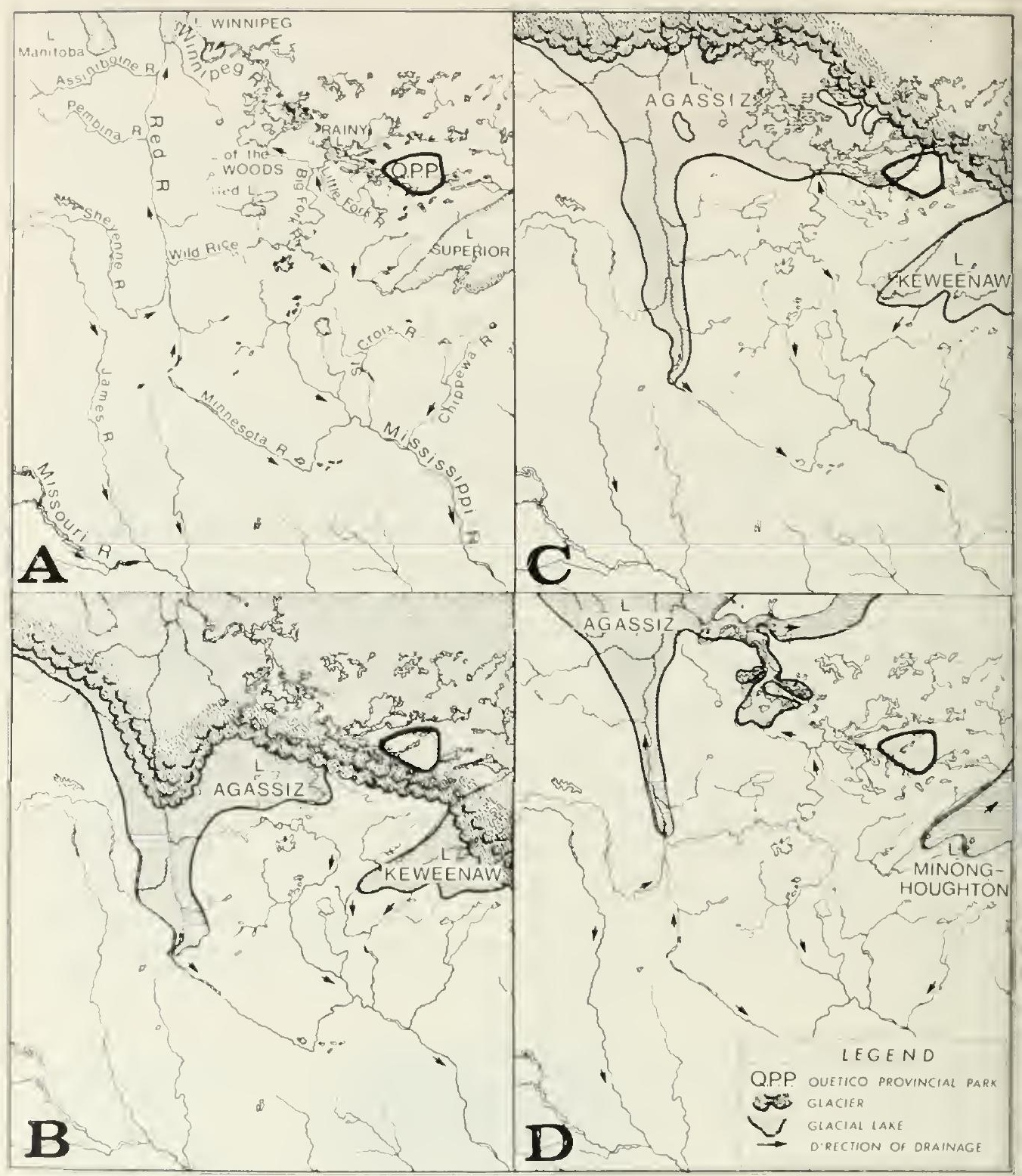

Fig. 2 Glacial history of Quetico
A. Present
B. 12,700 years before present
C. 12,400 years before present
D. 9,500 years before present 
The presence todaly of certam species in Quetico, and their absence in Ontario between Quetico and the lower Great Lakes, is evidence that they used the Lake Agassiz route from the Mississippi glacial refuge.

In man! parts of North America only a slight elevation and distances of a mile or less separate stream systems flowing in different directions. Thus for short periods. flooding can connect the headwaters of two distinct stream systems. Fishes can then pass, for example. from a stream system such as the Mississippi. which Hows to the Gulf of Mexico. into a stream system such as the Red, which flows to Hudson Bay (see Fig. 2A). In this way fishes can periodicalls invade new territory.

\section{Discussion of Fish Distribution}

As stated earlier, the original project from which this handbook developed was a survey of the waters of Quetico to determine whether there were any fishes that occurred there as well as in Minnesota, but not elsewhere to the north in Ontario. If there were. then we should have demonstrated that the old pathway from the Mississippi River, although now closed, is still a factor in the continuing northward spread of fishes.

The earliest list of fishes of Quetico Provincial Park was that of Lindeborg (1941). It listed 17 species taken from 18 Quetico lakes over a period of 10 weeks in 1935. The present list includes 49 species from a total of 195 localities. The difference of 31 species represents largely an increase both in effort and in the variety of habitats sampled. However, at least two species in my list. black crappie and largemouth bass, were introduced in or close to Quetico after Lindeborg's trip. The 1935 list contained no species that were not taken in the recent inventory, and so there has apparently been no drastic habitat change leading to extirpation.

All of the species at present known from Quetico occur both in Minnesota and elsewhere in Canada to the north, east, or west of Quetico. There are apparently no species which have only recently entered Canada by the old Mississippi-Quetico route. In contrast. Eddy and Underhill (1974) suggested that the presence of the ninespine stickleback. Pungitius pungitius. (at present unknown in Quetico) in the Mississippi waters of Minnesota may represent a southward migration resulting from floodwater connections with the Arctic drainage. It is not impossible that the present-day northern Minnesota distribution of some of the cold-water species (the five members of the family Salmonidae and the two sculpins) may represent a movement south during some intermediate stage of glaciation, or later. Most of those species must, however, have lived out the stage of maximum glaciation to the south of Minnesota, through which they must have passed to reach Quetico.

In contrast :o the lack of recent immigrants, it is of interest that there are a number of species which occur rather frequently in Quetico but are uncommon. or even rare, in the part of Minnesota adjacent to Quetico. The pumpkinseed. Lepomis gibbosus, and the longear sunfish. Lepomis megalotis, fit this category, 
according to range statements given by Eddy and Underhill (1974). The more significant of these species is probably the longear sunfish, of which these authors said: "We know of no other population [than that in Burditt Lake, Ontario, Gruchy and Scott, 1966] north of Iowa." This species was taken in seven Quetico locations and appeared to be more abundant there than in its other restricted areas of distribution in southern Ontario and southern Quebec. The green sunfish, Lepomis cyanellus, from 13 Quetico localities, and the tadpole madtom, Noturus gyrinus, from 24 Quetico localities, were both more common in Quetico than in some parts of their areas of distribution in southern Ontario.

Lepomis gibbosus and Lepomis megalotis do not occur north of Lake Superior, so that their populations in southern and western Ontario are disjunct. The western Ontario populations of these species are obviously of Red River origin. It would seem likely that these species moved northward through Minnesota and that conditions are now less suitable for them in that state. The distribution of another species, the stonecat, Noturus flarus, which does not occur in Quetico, may also be an example of depletion in the south. Eddy and Underhill (1974) stated that they had no records of this species in the Red River in Minnesota. It does, however, occur in the Red River in Manitoba.

The slimy sculpin, Cottus cognatus, appears to be limited to the northern portion of Quetico. Eddy and Underhill (1974) listed it as common in the Lake Superior drainage in Minnesota, present in Lake County in the Hudson Bay drainage, and of "general northern range". They said, however, that it was absent from the headwaters of the Mississippi and from the Red River system. This species is widespread, occurs all around Quetico, and could possibly have moved westward into the park from the Lake Superior drainage. However, the distribution in Manitoba and to the west would suggest a Red River route into Canada and an eastward spread into Quetico. If this sculpin is truly restricted to the northern portion of the park, its distribution, rather than being inconsistent with a Red River route into Canada, may simply reflect the tendency for this species to be restricted to cooler waters and to springfed headwaters. It is possible that for many species the habitats to the north are more suitable than the Red River, now silted and slow moving, which they must have used to reach the north. For an extensive discussion of this and of the role of the stages of glacial Lake Agassiz in the northward dispersal of fishes, see Elson (1967) and Eddy et al. (1972).

It would appear, then, that of the potential immigrants in Minnesota, described below, none had recently crossed into Canada in those Quetico waters which are so close to the Mississippi River watershed. The restricted number of species in Quetico waters would seem to indicate a recent problem of moving upstream into the Quetico headwaters of the Hudson Bay system rather than one of moving north into Canada from the Mississippi River watershed.

The total fish fauna of Minnesota, the source of potential migrants into Canada in the Quetico region, is approximately 155 species. A large number of these I would call southern species, since their northern limit of distribution is the Mississippi River in southern Minnesota. As such they are at present unavailable to Canadian waters. A more limited number of Mississippi River species, 58 , 
live in the headwaters above impassable St. Anthony Falls (Eddy et al., 1963). Of these. 24 species are at present unknown in Quetico. The distance between the south-flowing Mississippi River headwater tributaries and the north-flowing tributaries of the Border Waters is not great. In times of floods the wo systems might be connected. and some of these 24 species could begin the move into water flowing into Quetico. However, the shortest pathway would involve a connection between headwater streams of the Mississippi and Big Fork rivers. The Big Fork is a tributary of the Rainy River. downstream of the impassable dam at International Falls. This dam was built in 1909-1911 and has blocked the upstream migration of fishes to Quetico since that time.

Species living in the north-flowing Red River in Minnesota have had access to Quetico. Of the 59 species in the Red River system in Minnesota (Eddy and Underhill. 1974) 18 are still absent from Quetico. Six of these (the bowfin, Amia calva: the stoneroller, Campostoma anomalum; the weed shiner, Votropis texamus: the golden redhorse, Moxostoma erythrum; the white crappie, Pomoxis anmularis: and the least darter. Etheostoma microperca) have simply not had sufficient time. or else have not been capable of penetrating that far north. Eight species (the chestnut lamprey, Lhthomyzon castanews: the goldeye. Hiodon alosoides: the silver chub, Hybobsis storeriana; the bigmouth shiner. Notropis dorsalis; the sand shiner, Norropis stramineus; the black bullhead, Ictahurus melas: the banded killifish, Funduhus diaphamus: and the river darter. Percina shumardi) have penetrated Canada and have spread west or north in the Hudson Bay watershed. but not east toward the Hudson Bay headwaters of Quetico. Five other species (the rosyface shiner. Notropis mbellus: the channel catfish. Ictahurus punciatus; the brown bullhead, Ictalurus nebulosus; the ninespine stickleback. Pungitius pungitius; and the blackside darter. Percina maculata) have turned eastward but are presently not known upstream of either Lake of the Woods or Rainy Lake.

Eddy and Underhill (1974), under a number of distributional designations (including "everywhere", Lake of the Woods, Rainy River and/or Lake. Border Lakes). listed 56 species which are found in waters directly tributary to Quetico. Of these. 17 species are at present unknown in Quetico. The rainbow trout, Salmo gairdneri, and brown trout, Salmo Imulla, are present in that part of Minnesota as a result of fish culture activities, and they have not as yet spread north into Quetico or been stocked there. The pugnose shiner, Notropis anogemus; the bigmouth shiner. Notropis dorsalis; brassy minnow, Hybognathus hankinsoni: hornyhead chub, Nocomis biguttatus: golden redhorse. Moxostoma erythmum; and brook stickleback, Culaea inconstans, were said to be "everywhere" in Minnesota. All of these species. except Notropis anogenus, were said by Eddy et al. (1972) to be in the Rainy River system. They have either not crossed to the Canadian side or we have missed them, as none are at present known in the Canadian waters of that system, or in Quetico. The muskellunge, Esox masquinongy: river shiner, Notropis blennius; white sucker. Catostomus catostomms; ninespine stickleback, Pungitius pungitius; blackside darter, Percina maculata; and river darter. Percina shumardi, have been reported to be in Lake of the Woods and/or Rainy River but are at present unknown from Quetico. Some of these species 
have apparently failed to cross the Rainy River system into Canada. or had not penetrated eastward to Quetico before the construction of the dam at International Falls. This would appear to be the case also for such widespread northern species as the longnose sucker, Catostomus catostomus: brook stickleback. Culaea inconstans: and ninespine stickleback. Pungitius pungitius. Three other species, the goldeye, Hiodon alosoides: the muskellunge, Esox masquinongl: and the quillback. Carpoides cyprinus, which are reported from Lake of the Woods. are also unknown upstream. The occurrence of the goldeye has been obscured by the problem of distinguishing it from the mooneye. Hiodon tergisus. The goldeye is not known from the Canadian portion of Lake of the Woods or from the territory upstream. The closely related mooneye does occur in Lake of the Woods in Canada, and in Quetico. Heyerdahl and Smith (1972), in a discussion of changes in the faunal list for Lake of the Woods, seemed to imply that past records of goldeye actually applied to $H$. tergisus. They cited the reidentification (by Dr. J. C. Underhill) as H. tergisus of "12 specimens of a species known locally as goldeyes". Later they listed $H$. alosoides as a species once abundant but now rare. Eddy and Underhill (1974) listed H. alosoides as part of the commercial catch of Lake of the Woods and H. tergisus as present. That 1974 report of $\mathrm{H}$. alosoides in the commercial catch of Lake of the Woods should have referred to Red Lake in Minnesota (pers. comm., Underhill). The picture in regard to these two species may be further obscured by what seems like replacement of $H$. alosoides by $H$. tergisus resulting from environmental changes in the shallower, Minnesota portion of Lake of the Woods. The goldeye would appear to have been present in Lake of the Woods, to have declined after 1923, and to have been replaced by the mooneye. This would be unusual, however, since such environmental changes usually involve increased siltation and it is the goldeye, rather than the mooneye, which is more successful in silted waters. The muskellunge, Esox masquinongy, has been reported in Minnesota in Lake of the Woods, in Rainy River, and occasionally in waters along the border area. In Canada it is known to occur in the Rainy River, Rainy Lake, and Shoal Lake on the Seine River, but it is presently unknown in the park.

The creek chub, Semotilus atromaculatus, would appear to have been the last species to penetrate the headwaters from the west. as the doubtful Quetico records are restricted to the southwest portion of the park. Another possibility is that the species may have moved into Quetico from the Great Lakes watershed to the east. In order for it to pass westward from the headwaters of streams tributary to Lake Superior in Canada, it must overcome the height of land between the Pigeon River and Quetico headwaters. The presence of the lake chub. Couesius plumbeus, only in the northeastern portion of the park might suggest such a route, since that species is widely distributed in Great Lakes waters just to the west.

There are two possible routes for Great Lakes species to move north through Minnesota. These are connections between the St. Louis River (Great Lakes) and the Vermilion River or the Little Fork River. The Vermilion River is open to Quetico, but the Little Fork is not, as it is tributary to Rainy River below the dam. 
As mentioned above, it would appear that the low number and the composition of the Quetico fish fauna reflect the extent to which fishes had been able to penetrate to the headwaters of the Hudson Bay watershed before access was bloched by the building of the dam on the Rainy River. Furthermore, Quetico habitats would appear to provide suitable conditions for species which passed through northern Minnesota. but which may be unable to succeed there at present.

\section{Commercial Fishing}

Commercial fishing in Quetico-Superior has taken place sporadically at least since the 1930s, when it was carried out in the U.S. waters of Lac la Croix. That lake and its Canadian tributary, the Maligne River, are apparently the only waters which have supported such a fishery. The Lac la Croix Indian Band has traditionally taken fish in Quetico for its own use. However, commencing in 1959. licences were issued to the band to fish gill nets (after 1961, 12-inch mesh only) and in 1967 for set lines, for lake sturgeon. The number of men employed in this way was always small; between 1959 and 1962 it varied from 10 to 23. Sturgeon were dressed and sold to the Winnipeg markets. There has been a steady decline in the catch, as indicated in the table below. This decline, together with the facts that no catch was reported in 1968 and that there were no requests for licences after 1968, might suggest a collapse in the fishery from overfishing.

There has been no licensed commercial fishery in Quetico since 1968.

Commercial Fishing in Lac la Croix-Quetico Provincial Park

\begin{tabular}{|c|c|c|c|c|c|c|c|}
\hline Year & Walleye & Lake Sturgeon & Lake Whitefish & Total lbs. & $\begin{array}{l}\text { Total } \\
\text { Value in } S\end{array}$ & $\begin{array}{l}\text { Gill Net } \\
\text { Yards }\end{array}$ & $\begin{array}{l}\text { No. of Hooks } \\
\text { in Set Lines }\end{array}$ \\
\hline 1959 & & 9.151 & - & 9,151 & 5,491 & 2,000 & . \\
\hline 1960 & - & 11,256 & 872 & 12,128 & 9,284 & 3.000 & - \\
\hline 1961 & 81 & 5,082 & 2,823 & 7,986 & 5,702 & 3,000 & - \\
\hline 1962 & - & 5,298 & - & 5,298 & 4.715 & 3.000 & - \\
\hline 1963 & - & 4,902 & - & 4,902 & 4,902 & 2,000 & - \\
\hline 1964 & - & 3.021 & - & 3,021 & 3,021 & 2.000 & - \\
\hline 1965 & - & 1.413 & - & 1,413 & 1.413 & 1.000 & - \\
\hline 1966 & - & $1,7.32$ & - & 1,732 & 1,732 & 1,000 & - \\
\hline 1967 & - & - & - & - & - & - & 300 \\
\hline 1968 & . & - & - & - & - & 2,000 & - \\
\hline
\end{tabular}




\section{Acknowledgments}

When a project such as this one has spread over nine years there is a correspondingly large number of people to whom acknowledgment is due for help in the field, in the laboratory, or as correspondents who provided information or helped improve the manuscript.

Primary acknowledgment is due the Quetico Foundation, which supported the initiation of the project with encouragement and financial assistance, and largely funded the publication of this report. After 1967 the inventory of Quetico fishes was a joint project involving the ROM and the Ontario Department of Lands and Forests (now Ministry of Natural Resources). I would like to extend my thanks to that organization and particularly to Mr. F. P. Maher, Mr. Bruce Caldwell, and the succession of student field crews who did so well under the difficulties of survey work in canoe country.

In no lesser degree I should like to thank the following individuals who helped in a variety of ways: R. Alton, R. A. Balkwill, B. Beange, F. Dustak, D. Ernst, P. L. Heinrich, D. P. Kolenosky, N. V. Martin, R. M. Odell, L. F. Ohmann, S. Poray (who prepared Fig. 1), R.R. Ream, W.B. Scott, G.E. Taylor, J. C. Underhill, S. Walshe, J. O. Wernham, and C. R. Williams.

The frustrating and time-consuming tasks of summarizing data and compiling and cross-checking the lengthy distribution lists were carried out first by Stephen Campbell and later by Margaret Crossman, both of whom I should like to thank. 


\section{Literature Cited and Suggested Reading}

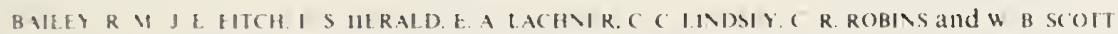

1970 A list of common and scientific names of fishes from the United States and Canada. 3rd ed. American lisheries Society Special Publication, No. 6. Washington. D.C.. American Fisheries Societs. $150 \mathrm{pp}$.

B.LWIV।

MS1947 A report on the Quetico Park creel census for 1947. Toronto. Fishery Investigation of the Disision of Research. Ontario Department of Lands and Forests. $10 \mathrm{pp}$.

BODUE, $T$ J H.. C. A ELSEY and B CALDWELL.

1964 A fisheries survey of Lac la Crolx 1963. Minnesota Dep. Conserv., Dir. Game Fish. Invest. Rep. 281: I 10.

DF VIS $h$

1959 Canoe trails through Quetico. Toronto, Quetico Foundation. 84 pp.

t.DDY S. J B Vorti. and J.C. L VDt RHIL.L.

1963 The fish fauna of the Mississippi River above St. Anthony Falls as related to the effecliveness of this falls as a migration barrier. Proc. Mınn. Acad. Sci., 30(2):111-115.

EDDY S R C TISNER and I C I VDTRHILt

1972 Fishes of the Red River. Rainy River. and Lake of the Woods, Mınnesota, with comments on the distribution of species in the Nelson River Drainage. Occ. Pap. Univ. Minn. Mus. Nat. Hist.. 11: 1-24

t DDY. S and I C I VDERHLL.

1959 Recent changes and corrections for the Minnesota fish fauna. Copeia, 4: $342-343$.

1974 Vorthern fishes. Minneapolis. University of Mınnesota Press. 414 pp.

L.LSO\, +

1967 Geology of glacial Lake Agassiz. Pp. 37-95. In Mayer-Oakes. W. J.. ed. Life. land and water. Winnipeg. University of Maniloba Press. $414 \mathrm{pp}$.

I. IR WAY B $W$ and $H$ B. I AIIVER

1910 The fishes of the Lake of the Woods and connecting waters. Proc. U.S. Natn. Mus., 39: $121-136$.

IIDORLK + V

197I Freshwater fishes of Manitoba: checklist and keys. Winnipeg. Manitoba Department of Mines, Resources, and Environmental Management. $130 \mathrm{pp}$.

GRLCHY C $G$ and $u$ B SCOTI

1966 Lepomis megalotis, the longear sunfish, in western Ontario. J. Fish. Res. Bd. Can.. 23(9): 14571459.

IIF TERDAHL. \&. C. and I. I. SMITH. JR.

1972 Fishery resources of Lake of the Woods, Minnesota. Tech. Bull. Mınn. Agric. I:xp. Sin.. 288: $1-145$.

III BBS ( 1 .

1945 Corrected distributional records for Minnesota fishes. Copeia. 1: 1322.

IIL BBS. C L and K F I AGITR

1964 Fishes of the Great Lakes Region. Ann Arbor. Universily of Vichigan Press. 213 pp. 
IIDDIBORC, R ;

1941 Records of fishes from the Quetico Provincial Park of Ontario, with comments on the grow th of the yellow pike-perch. Copeia, 3: 159-161.

1.1TTI.1.1011). B 11

1965 Quetico-Superior Country; wilderness highway to wilderness recreatıon. Toronto, Quetico Foundation. 31 pp. Reprinted from Canadian Geographical Journal, 71(2) -7l(3). Aug. Sept. 1965: 40-55.78-91.

MA h i H H 11

1963 Fishes of Ontario. Ioronto, Ontario Department of Lands and Forests. $300 \mathrm{pp}$. MARII \I

MSI947 Quetico Provincial Park creel census 1946. Toronto. Ontario Department of Lands and Forests. $16 \mathrm{pp}$.

OLSO\. S. 1

1972 Sigurd F. Olson's wilderness days. New York. A. A. Knopf. 233 pp. SCIDYORI W J.. C.A LLSEY and B (AI.I)WELI

1961 A fisheries survey of Basswood Lake 1960. Minnesota Dep. Conserv.. Div. Game Fish. Invest. Rep.. 241: 1-12.

SCOII U B

1972 Freshwater fishes of eastern Canada. 2nd ed. Toronto. Unversity of Toronto Press. 137 pp.

ScOII W B. and F J. CROSSMAN

1973 Freshwater fishes of Canada. Bull. Fish. Res. Bd. Can.. 184: $1=966$. [ NDERHII.I. J (

1957 The distribution of Minnesota minnows and darters in relation to pleistocene glaciation. Occ. Pap. Univ. Minn. Mus. Nat. Hist., 7: 1-45.

( \DI RHILL. J $\mathrm{C}$ and J. B. MOYLt.

1968 The fishes of Minnesota's Lake Superior Region. Conserv. Volunt.. 31(177): 29.53. 


\section{Index to Scientific and Common Names}

The index lists only the scientific name and the accepted common name. The bold face page number designates the species account, the other page number is for the entry for that species in the "List of Species and the Bodies of Water from Which They Are Known".

Aciperiser fulvescens. 3. 54

Ambloplites rupestris, 15.58

black crappie. 25.59

blackichin shiner, 41,56

blacknose dace, $\mathbf{4 5} .57$

blacknose shiner, 41,56

bloater, 11

bluegill. 19. 58

bluntnose minnow, 43. 56

brook trout, 33, 54

burbot. 49, 58

Catostomus commersoni. 47, 57

central mudminnow, 35, 55

Chrosomus eos, 37.55

Chrosomus neogaeus, 37, 55

cisco. 10, 54

common shiner, 41.56

Coregorus arledii, 10. 54

Coregonus clupeaformis, 11, 55

Coregonus hovi, 11

Coregonus zenithicus. 11, 55

Coltus bairdi. 53. 60

Cottus cognatus, 53. 60

Conesius plumbeus, 39. 56

creek chub, 47, 57

emerald shiner, 39. 56

Esox lucius. 13, 55

Esox masquinongu. 14

Etheostoma exile, 51, 59

Etheostoma nigrum. 51. 59 fathead minnow, 45. 57

finescale dace, 37,55

golden shiner, 39.56

green sunfish. 16, 58

Hiodon tergisus, 35, 55

Ichthyomyzon unicuspis. 33, 54

Iowa darter, 51. 59

Johnny darter, 51.59

lake chub, 39, 56

lake sturgeon, 3. 54

lake trout, 4. 54

lake whitefish, 11, 55

largemouth bass, 23. 58

Lepomis cyanellus, 16,58

Lepornis gibbosus, 17,58

Lepomis macrochirus, 19.58

Lepomis megaloris, 20. 58

log perch, 53, 59

longear sunfish. 20.58

longnose dace, 45, 57

Lota lota, 49, 58

Micropterus dolomieni, 21, 58

Micropterus salmoides, 23, 58

mimic shiner, 43, 56

mooneye, $\mathbf{3 5}, 55$

mottled sculpin, 53, 60

Moxosioma anisurum, 47, 57

Moxostoma macrolepidotum, 49.57 
muskellunge. 14

northern pike, 13, 55

northern redbelly dace, 37,55

Notemigonus crysoleucas, 39, 56

Notropis atherinoides, 39.56

Notropis cornutus, $\mathbf{4 1 . 5 6}$

Notropis heterodon, 41, 56

Notropis heterolepis, 41, 56

Notropis hudsonius, $\mathbf{4 3}, 56$

Notropis volucellus, 43, 56

Noturus gyrinus, 49, 57

Osmerus mordax, $\mathbf{3 5 , 5 5}$

pearl dace, 47,57

Perca flavescens, 27, 59

Percina caprodes, 53, 59

Percopsis omiscomaycus, 51, 58

pickerel (walleye), 29, 60

Pimephales notatus, 43, 56

Pimephales promelas, $\mathbf{4 5 .} 57$

Pomoxis nigromaculatus, 25, 59

pumpkinseed, 17, 58

rainbow smelt, $\mathbf{3 5}, 55$

Rhinichthys atratulus, 45, 57

Rhinichthys cataractae, 45, 57 rock bass, $\mathbf{1 5}, 58$

Salvelinus fontinalis, 33. 54

Salvelinus namaycush, 4. 54

sauger, 28, 59

Semotilus atromaculatus, 47,57

Semotilus margarita, 47, 57

shorthead redhorse, 49, 57

shortjaw cisco, 11. 55

silver lamprey, 33, 54

silver pike, 14

silver redhorse, 47, 57

slimy sculpin, 53, 60

smallmouth bass, 21.58

spottail shiner, $\mathbf{4 3}, 56$

Stizostedion canadense, 28. 59

Stizostedion vitreum, 29, 60

tadpole madtom, 49.57

trout-perch, 51, 58

Umbra limi, 35. 55

walleye, 29, 60

white sucker, 47,57

yellow perch, 27, 59 


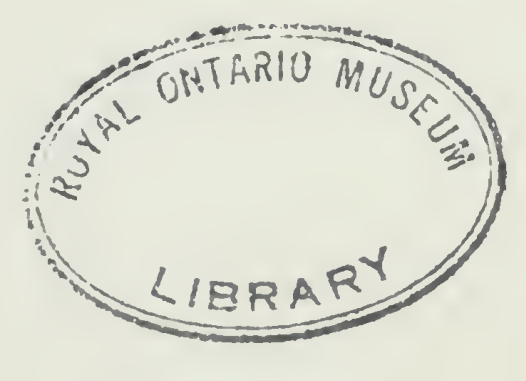




\section{ISBN 0-88854-180-5}

